\title{
LAWS AS TREATIES?: THE CONSTITUTIONALITY OF CONGRESSIONAL-EXECUTIVE AGREEMENTS
}

\author{
John C. Yoo* \\ TABLE OF CONTENTS
}

INTRODUCTION

I. CONGRESSIONAL-EXECUTIVE AGREEMENTS AND THE

INTERNATIONALIST VISION

A. The Current Importance of Congressional-Executive

Agreements

1. The Explosion of Congressional-Executive Agreements ....... 765

2. The Lack of Textual Support .

3. Interchangeability with Treaties

B. The Defects of Interchangeability ................................................773

1. The Internationalist View and Its Defects...............................773

2. The Transformationist Effort at Rehabilitation and Its Faults

3. The Response to the Transformationists: Treaty

Exclusivity

II. Practice, Public Lawmaking, AND the Congressional-

EXECUTIVE AGREEMENT

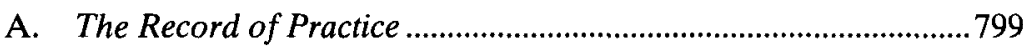

B. Structural Problems Created by Interchangeability .......................813

1. Congressional-Executive Agreements and the Foreign Affairs Power.

2. Interchangeability and the Lack of Limits on the Treaty Power.....

III. TOWARD A THEORY OF CONGRESSIONAL-EXECUTIVE

AGREEMENTS

* Professor of Law, University of California at Berkeley School of Law (Boalt Hall). A.B. 1989, Harvard; J.D. 1992, Yale. - Ed. I thank Curt Bradley, Jesse Choper, Viet Dinh, Phil Frickey, David Golove, Andrew Guzman, Jack Goldsmith, John Manning, Laurent Mayali, Henry Monaghan, Robert Post, Sai Prakash, Howard Shelanski, Judge Laurence Silberman, Peter Spiro, and Adrian Vermeule for their comments. Michael Zara provided superb research assistance. This Article benefited from a workshop at the University of Chicago Law School and a panel of the Society for Historians of American Foreign Relations. The John M. Olin Foundation, the Committee on Research of the University of California at Berkeley, and the Boalt Hall Fund generously provided financial support for this research. 
A. A Theory of Congressional-Executive Agreements ......................822

B. Solving the Conflict Between Articles I and II.............................831

1. The Original Understanding....................................................832

2. Congressional-Executive Agreements as a Defense of the Legislative Power

3. Congressional-Executive Agreements as Public Lawmaking

C. Statutes, Treaties, and the Future of International Agreements.... 848

\section{INTRODUCTION}

Only twice in the last century, in 1919 with the Treaty of Versailles, and two years ago with the comprehensive Nuclear Test-Ban Treaty, ${ }^{1}$ has the Senate rejected a significant treaty sought by the President. In both cases, the international agreement received support from a majority of the Senators, but failed to reach the two-thirds supermajority required by Article II, Section 2, of the Constitution. ${ }^{2}$ The failure of the Versailles Treaty resulted in a shattering defeat for President Wilson's vision of a new world order, based on collective security and led by the United States. Rejection of the Test-Ban Treaty amounted to a major setback for the Clinton administration's arms control policies and its efforts to promote American participation in international efforts at regulatory cooperation. In both cases, presidents raised the concern that a minority of the Senate could frustrate an internationalist American foreign policy and thereby turn the nation toward isolationism.

According to most international law scholars and authorities, however, both presidents easily could have evaded the Treaty Clause by submitting their international agreements as statutes. Instead of navigating Article II's advice-and-consent process, presidents have sent many international agreements to both houses of Congress for simple majority approval. Known as congressional-executive agreements, these instruments are indistinguishable under international law from treaties in their ability to bind the United States to international obligations. Several recent agreements of significance, such as the North American Free Trade Agreement ("NAFTA") 3 and the World Trade

1. See Sen. Jon Kyl, Maintaining "Peace Through Strength": A Rejection of the Comprehensive Test Ban Treaty, 37 HARV. J. ON LEGIS. 325 (2000).

2. U.S. CONST. art. II, $\$ 2, \mathrm{cl} .2$ (The President "shall have Power, by and with the Advice and Consent of the Senate, to make Treaties, provided two thirds of the Senators present concur.").

3. See North American Free Trade Agreement, done Dec. 17, 1992, 107 Stat. 2057, 32 I.L.M. 289 . 
Organization ("WTO") agreement, ${ }^{4}$ have undergone this statutory process. Not surprisingly, presidents have favored this easier route to making international agreements. While in the first fifty years of American history, the nation concluded twice as many treaties as nontreaty agreements, since World War II the nation has concluded more than ninety percent of its international agreements through a nontreaty mechanism. ${ }^{5}$

Despite the fact that the constitutional text includes a specific Treaty Clause but no other means to enter into international agreements, a broad intellectual consensus exists that congressionalexecutive agreements may serve as full substitutes for treaties. As Professor Louis Henkin, the dean of American foreign relations law scholars, writes, "it is now widely accepted that the CongressionalExecutive agreement is available for wide use, even general use, and is a complete alternative to a treaty." "Declares the Restatement (Third) of United States Foreign Relations Law: "The prevailing view is that the Congressional-Executive agreement can be used as an alternative to the treaty method in every instance." Under this theory of "interchangeability," congressional-executive agreements and treaties are indistinguishable from one another, with the result that the former may enjoy all of the benefits that accrue to the latter, despite the easier method for enacting statutes. Rather than a supermajoritarian barrier to international agreement-making, the Treaty Clause becomes merely an alternative method for making contracts with other nations. According to this logic, President Bush could now resubmit the TestBan Treaty to Congress for approval by majority vote, and President Wilson could have brought the United States into the League of Nations through a statute, even after the defeat of both agreements in the Senate. Few constitutional provisions seem so easily evaded.

4. See Final Act Embodying the Results of the Uruguay Round of Multilateral Trade Negotiations, Apr. 15, 1994, 108 Stat. 4809, 33 I.L.M. 1125.

5. See CONG. RESEARCH SERV, 103D CONG., TREATIES AND OTHER INTERNATIONAL AGREEMENTS: THE ROLE OF THE UNITED STATES SENATE 15 (Comm. Print 1993) [hereinafter SENATE 1993 REPORT]. While these nontreaty numbers include both congressionalexecutive agreements and sole executive agreements, most of these agreements appear to have undergone approval by both houses of Congress. See id. at 16.

6. LOUIS HENKIN, FOREIGN AFFAIRS AND THE UNITED STATES CONSTITUTION 217 (2d ed. 1996) [hereinafter HENKIN, FOREIGN AFFAIRS]; see also MICHAEL J. GLENNON, CONSTITUTIONAL DiPLOMACY (1990); HAROLD HONGJU KOH, THE NATIONAL SECURITY CONSTITUTION: SHARING POWER AFTER THE IRAN-CONTRA AFFAIR (1990); Philip R. Trimble \& Jack S. Weiss, The Role of the President, the Senate and Congress with Respect to Arms Control Treaties Concluded by the United States, 67 CHI.-KENT L. REV. 645 (1991).

7. RESTATEMENT (THIRD) OF THE FOREIGN RELATIONS LAW OF THE UNITED STATES $\S 303 \mathrm{cmt}$. e (1987). 
This striking divergence between the constitutional text and practice is not just a matter of intellectual curiosity. International agreements today are assuming center stage in efforts to regulate areas such as national security, the environment, trade and finance, and human rights. ${ }^{8}$ In order to establish effective global solutions, treaties have come to resemble domestic legislation in directly mandating norms of public and private conduct. ${ }^{9}$ As international agreements increasingly assume the function of statutes, the treaty power - an executive power that excludes the House of Representatives - threatens to supplant the domestic lawmaking process, even in areas within Congress's Article I, Section 8 competencies. ${ }^{10}$ At the same time, interchangeability raises the prospect that statutes could fully replace treaties, which raises the mirror-image problem that Congress could come to exercise executive powers in areas where treaties have force beyond domestic statutes. While this may not have presented much of a practical problem in an era when the Commerce Clause's reach was thought to be virtually limitless, the Supreme Court's recent federalism decisions - which, for example, have limited Congress's authority to expand civil rights protections ${ }^{11}$ - make clear that significant areas still exist where treaties provide the sole constitutional source for national regulatory power. Interchangeability would permit statutes to evade the restrictions on Congress's Article I, Section 8 powers, just as globalization threatens to allow the executive treaty power to invade the domestic lawmaking process.

Explaining the constitutionality of the congressional-executive agreement is a matter not just of intellectual coherence, but of practical economic and political importance. Today, about one-quarter of the gross national product arises from international trade, whose rules are set by the NAFTA and WTO agreements. ${ }^{12}$ If all international agreements must undergo the supermajority treaty process, it is likely

8. See John C. Yoo, Globalism and the Constitution: Treaties, Non-Self-Execution, and the Original Understanding, 99 COLUM. L. REV. 1955, 1956-57 (1999) [hereinafter Yoo, Globalism].

9. See id. at 1967-69.

10. In other work, I have argued that, for textual and structural reasons, treaties which seek to regulate areas within Article I, Section 8 subject matters should be deemed non-selfexecuting, so as to preserve Congress's monopoly over domestic legislation. See generally John C. Yoo, Treaties and Public Lawmaking: A Textual and Structural Defense of Non-SelfExecution, 99 COLUM. L. REV. 2218, 2233-57 (1999) [hereinafter Yoo, Non-Self-Execution].

11. See Kimel v. Florida Bd. of Regents, 528 U.S. 62 (2000); College Sav. Bank v. Florida Prepaid Postsecondary Educ. Expense Bd., 527 U.S. 666 (1999); City of Boerne v. Flores, 521 U.S. 507, 511 (1997). For criticism of the Supreme Court's recent decisions invalidating civil rights statutes as beyond congressional power, see, e.g., Robert C. Post \& Reva B. Siegel, Equal Protection by Law: Federal Antidiscrimination Legislation After Morrison and Kimel, 110 YALE L.J. 441 (2000).

12. See ECONOMic RePort of the President, H.R. Doc. No. 105-176, at 216 (2d Sess. 1998). 
that America's ability to participate in a new world of international cooperation will be hampered. On the other hand, use of a constitutionally illegitimate method would throw America's participation in the world trading system into doubt. Not only would constitutional questions undermine the validity of current congressional-executive agreements, they also would raise problems for America's ability to engage in ever more intensive efforts at international cooperation. Uncertainty about the constitutionality of the congressional-executive agreement may inhibit the ability of the public lawmaking system to embrace novel efforts to craft international solutions in response to the effects of globalization on areas such as international finance and economics, security, the environment, and human rights.

Resolving the looming conflict between globalization and the American public lawmaking process requires us to consider carefully the scope of treaties, the reach of statutes, and how to reconcile the two. Within the context of the debate over the constitutionality of the congressional-executive agreement, this Article will develop a theory that allows us to understand the difference between treaties and statutes and the subject matter appropriate for each - a difference that permits us to maintain important distinctions between international lawmaking and domestic lawmaking in an age of rapid globalization. This distinction provides the foundation for determining when congressional-executive agreements are a constitutional mode of international agreement. Unfortunately, our leading constitutional scholars have failed to understand that the debate over the congressionalexecutive agreement actually embodies deeper structural questions concerning the proper relationship between the treatymaking and the domestic lawmaking processes.

Instead of seeking to harmonize the respective scopes of treaties and statutes, many in the academy have embraced extreme positions that eviscerate either the treaty or the congressional-executive agreement. Traditional international law scholars, for example, too willingly embrace complete interchangeability while brushing aside severe textual and structural problems with eliding statutes and treaties. Professors Bruce Ackerman and David Golove also defend full interchangeability, but only on the basis of their provocative and idiosyncratic theory of unwritten constitutional amendments. ${ }^{13}$ Professor Laurence Tribe, on the other hand, argues that congressional-executive agree-

13. See Bruce Ackerman \& David Golove, Is NAFTA Constitutional, 108 HARV. L. REV. 799 (1995). For more complete articulations of the "constitutional moments" theory, see 1 BRUCE ACKERMAN, WE THE PEOPLE: FOUNDATIONS (1991) [hereinafter ACKerman, We the People: Foundations]; 2 Bruce ACKerman, We the People: TRANSFORMATIONS (1998) [hereinafter ACKERMAN, WE THE PEOPLE: TRANSFORMATIONS]. 
ments like NAFTA and the WTO violate the Constitution. ${ }^{14}$ Because the Constitution only addresses international agreements in the Treaty Clause, Tribe concludes that all significant international agreements must undergo a supermajority vote in the Senate - a theory of treaty exclusivity. Ackerman, Golove, and Tribe fail to see that the question of the congressional-executive agreement actually turns on the proper line between the executive treaty power and Congress's legislative power, and on the changes globalization has wrought upon the domestic lawmaking process. ${ }^{15}$ Because of this, they fail to see that adopting either interchangeability or treaty exclusivity would lead to unacceptable distortions of the constitutional structure and would require the rejection of more than a half century of practice by the political branches.

This Article will provide a constitutional justification for the congressional-executive agreement, one consistent with the text, structure, and history of the Constitution. It will provide a clear dividing line that demarcates the situations in which treaties must be the sole instrument of national policy, and those that can be dealt with by the congressional-executive agreement. This Article is the first to base its theory of treaties upon the record of practice by the political branches, rather than making normative claims derived simply from different

14. See Laurence H. Tribe, Taking Text and Structure Seriously: Reflections on FreeForm Method in Constitutional Interpretation, 108 HARV. L. REV. 1221 (1995).

15. Recently, two articles have addressed the debate over interchangeability with differing results. Compare Peter J. Spiro, Constitutional Method and the Great Treaty Debate, 79 TEXAS L. REV. (forthcoming 2001), with Joel R. Paul, The Geopolitical Constitution: Executive Expediency and Executive Agreements, 86 CAL. L. REV. 671 (1998). Although Professor Spiro's article shares several of this Article's methodological doubts about both the Ackerman/Golove and Tribe approaches, he does not attempt to develop a theory about the differences between treaties and congressional-executive agreements or about the constitutional principles that should govern international agreements. Rather, Professor Spiro seeks to use the issue as the springboard for a general theory of constitutional change. Professor Paul claims in part that that congressional-executive agreements resulted from the expansion in executive power due to the increased geopolitical demands on the Constitution after World War II. He argues that now that these problems have receded with the end of the Cold War (itself a debatable proposition), we should return to constitutional practices that comport more closely to the original Constitution. Paul's conclusions are quite similar to those of Professors Arthur Schlesinger, Jr. and Jules Lobel, who have argued that the Cold War period led to an emergency powers model of the Constitution that improperly expanded the presidential authority in foreign affairs. See generally ARTHUR M. SCHLESINGER, JR., THE IMPERIAL PRESIDENCY (1973); Jules Lobel, Emergency Power and the Decline of Liberalism, 98 YALE L.J. 1385 (1989). Paul would conclude, as would Schlesinger and Lobel, that treaties should be the only method for making international agreements. I find Professor Paul's analysis lacking, however, in its failure to examine the relationship between treaties and statutes in light of the distribution of authority between the legislative and executive branches in Articles I and II, and in its haste to discard the significant practice of international agreement-making by the political branches. See infra text accompanying notes $142-311$. 
theories of constitutional interpretation. ${ }^{16}$ Practice suggests that complete interchangeability ought to be rejected because it creates severe distortions in the American public lawmaking system. Allowing statutes completely to replace treaties eliminates the restrictions upon Congress's enumerated powers and undermines the separation of powers in foreign affairs. Nor is treaty exclusivity an acceptable alternative. Congressional-executive agreements still have a legitimate place in the constitutional conduct of foreign policy, because their use preserves Congress's constitutional powers over matters such as international commerce. ${ }^{17}$

This Article will also demonstrate that a proper place still exists for the operation of treaties, even in a world of expanded congressional powers, and it will seek to define that place. Treaties, for example, still remain an indispensable instrument for regulating subjects that rest outside of Congress's Article I powers. Recent federalism decisions by the Supreme Court make clear that several areas rest outside of Congress's enumerated authority: areas beyond the reach of the Commerce Clause, ${ }^{18}$ the commandeering of the executive or legislative branches of the state governments, ${ }^{19}$ overriding state sovereign immunity in either federal or state court (when the Reconstruction Amendments are not involved) ${ }^{20}$ and expanding the constitutional definition of civil rights that may apply against the states. ${ }^{21}$ While the lawmakers run into their constitutional boundaries in these areas, the treatymakers may still use their powers to reach beyond the limits of the Commerce Clause and the Tenth Amendment. Treaties also are required for the national government to act in areas that are the subject of the concurrent powers of the executive and legislative branches.

16. As far as I can tell, no legal scholar has attempted to conduct an empirical survey of the use of treaties versus congressional-executive agreements to regulate different subjects.

17. Thus, treaties cannot be self-executing in such areas, because to allow the treatymakers to regulate such matters would infringe the Constitution's vesting of the federal legislative power in Congress alone. I have provided a fuller account of the doctrine of nonself-executing treaties elsewhere. See generally Yoo, Globalism, supra note 8 (arguing that original understanding supports doctrine of non-self-executing treaties); Yoo, NonSelf-Execution, supra note 10 (arguing that text and structure justify non-self-execution).

18. See, e.g., United States v. Morrison, 529 U.S. 598 (2000) (striking down federal civil cause of action for gender-motivated violence); United States v. Lopez, 514 U.S. 549 (1995) (invalidating federal law banning handgun possession in school zones).

19. See, e.g., Printz v. United States, 521 U.S. 898 (1997); New York v. United States, 505 U.S. 144 (1992).

20. See Alden v. Maine, 527 U.S. 706 (1999); Seminole Tribe of Fla. v. Florida, 517 U.S. 44 (1996).

21. See Kimel v. Florida Bd. of Regents, 528 U.S. 62 (2000); College Sav. Bank v. Florida Prepaid Postsecondary Educ. Expense Bd., 527 U.S. 666 (1999); City of Boerne v. Flores, 521 U.S. 507, 511 (1997). 
Congressional-executive agreements present a way for the political branches to maintain the distinction between treatymaking and lawmaking. This Article argues that the normal statutory mode must be used to approve international agreements that regulate matters within Congress's Article I powers. The device of the congressional-executive agreement ensures that the same public lawmaking process will apply to the same subjects, regardless of whether an international agreement is involved or not. This approach leaves ample room for treaties, which still must be used if the nation seeks to make agreements outside of Congress's competence or bind itself in areas where both President and Congress exercise competing, overlapping powers. Maintaining this line - which, unlike the Ackerman-Golove, Tribe, or traditional international law approaches, comports with the practice of the political branches - ensures that the spheres of the executive foreign affairs power and of domestic public lawmaking do not intrude into one another.

The Article will proceed in three parts. Part I will describe the importance of congressional-executive agreements, their lack of support in the constitutional text, and scholarly efforts to justify their use. It also will discuss and critique the recent, contending academic theories concerning the interchangeability of treaties and statutes. Part II will argue against complete interchangeability by identifying its severe textual and structural problems. Part III proposes a new approach to the congressional-executive agreement and explains its superiority to the theory that treaties must be used to make all international agreements.

\section{CONGRESSIONAL-EXECUTIVE AGREEMENTS AND THE INTERNATIONALIST VISION}

This Part will provide the necessary context for a discussion of congressional-executive agreements. Section A describes the status of congressional-executive agreements today and reviews the doctrine of interchangeability. Section B discusses and critiques the different constitutional theories that have arisen to justify the use of statutes to make international agreements. It finds that even as congressionalexecutive agreements have assumed a significant role in American foreign policy, academic theories defending this instrument have been lacking. If these scholars are right, significant elements of America's participation in the postwar world order apparently rest on foundations of dubious constitutionality.

\section{A. The Current Importance of Congressional-Executive Agreements}

During the postwar period, the political branches have come to rely upon congressional-executive agreements as one of the primary instruments of American foreign policy. Several of the nation's most 
important international obligations, such as the international financial order established by the Bretton Woods agreement, the world trading system created by the General Agreement on Tariffs and Trade ("GATT") and WTO, and our regional trading regime established by NAFTA, have been enacted by a simple majority vote in both houses of Congress. This Section will first describe the increasing use of congressional-executive agreements to make international agreements. It will then discuss the lack of support in the constitutional text for the use of such instruments. It will conclude by reviewing the doctrine of interchangeability, by which international law authorities argue that congressional-executive agreements may serve as a perfect substitute for treaties.

\section{The Explosion of Congressional-Executive Agreements}

Before examining the constitutionality of congressional-executive agreements, some definitions are in order. When using the phrase "congressional-executive agreement," some do not distinguish between two analytically distinct methods of agreement - congressional-executive agreements, which require participation by both houses of Congress, and sole executive agreements, in which the President unilaterally reaches an agreement with another nation in areas of his plenary executive authority. ${ }^{22}$ This Article will address only the former; the latter do not raise the same constitutional problems, as they are not considered to be interchangeable with treaties. Within the category of congressional-executive agreements, there are three types. First, Congress may provide ex ante authorization to the President to reach agreements with other nations on certain discrete subjects. In 1792, for example, Congress authorized the Postmaster General to reach arrangements for the exchange of mail. ${ }^{23}$ Second, Congress may legislate on a foreign relations matter, in which the President must determine the existence of certain facts before a statute can take effect. In the area of reciprocal trade agreements, for example, Congress will mandate the reduction of tariffs on a country's goods, but only when the President reports that the other country will drop its tariffs on

22. President Franklin Roosevelt's negotiation of the Litvinov assignment, which was part of the recognition of the Soviet Union, is an example of a sole executive agreement. Since the agreement involved the President's powers over recognition and his power to settle claims, it could preempt inconsistent state law. See United States v. Pink, 315 U.S. 203 (1942); United States v. Belmont, 301 U.S. 324 (1937). If the President had sought to reach agreements outside of his plenary constitutional powers, the agreement could not have exercised such domestic legal effects. See Michael D. Ramsey, Executive Agreements and the (Non) Treaty Power, 77 N.C. L. REV. 133 (1998).

23. See Act of Feb. 20, 1792, ch. 7, § 26, 1 Stat. 232, 239. 
American products. While facially domestic in nature, this arrangement produces international agreements because Presidents may negotiate with other nations to ensure reciprocal tariff reductions. ${ }^{24}$ This Article will focus only on a third type. This arises when the President has negotiated an international agreement and seeks ex post approval from Congress, which is usually bundled with provisions implementing the agreement in domestic law. Unlike the first two types of agreements, this third type does not involve the delegation of authority from Congress to the President, but instead seeks to replace the treaty process with a statutory one.

Congressional-executive agreements of the third type have become one of the central tools in the exercise of American foreign policy. In the early period of the nation's history, the treaty process held a virtual monopoly on the making of agreements. ${ }^{25}$ During the 1789-1839 period, the nation entered into sixty treaties and only twenty-seven nontreaty international agreements. ${ }^{26}$ Many of the early nation's most significant international commitments, such as the Jay and Pinckney Treaties and the Louisiana Purchase, were concluded as treaties. As the nation entered World War II, however, statutory devices or even unilateral executive action came to overwhelm the treaty process as the preferred method for making international agreements. From 1939-1989, for example, the nation entered into 11,698 nontreaty agreements but only 702 treaties. ${ }^{27} \mathrm{~A}$ congressional study has found that between 1946 and 1972, 88.3 percent of all international agreements made by the United States took a statutory form, only 6.2 percent were treaties, and the remaining 5.5 percent were sole executive agreements. ${ }^{28}$ The following charts illustrate the heavy use of the congressional-executive agreement as an alternative to the treaty process since 1939.

\footnotetext{
24. See Field v. Clark, 143 U.S. 649, 682-92 (1892).

25. See G. Edward White, The Transformation of the Constitutional Regime of Foreign Relations, 85 VA. L. REV. 1, 9-21 (1999) (explaining the historical development of treaty power jurisprudence).

26. See SENATE 1993 RePORT, supra note 5, at 14 tbl. 2.

27. See id.

28. See id. at 16 .
} 
EXeCutive AgreEMENTS ANd Treaties ConCluded By THE UNITED STATES, 1930-1992

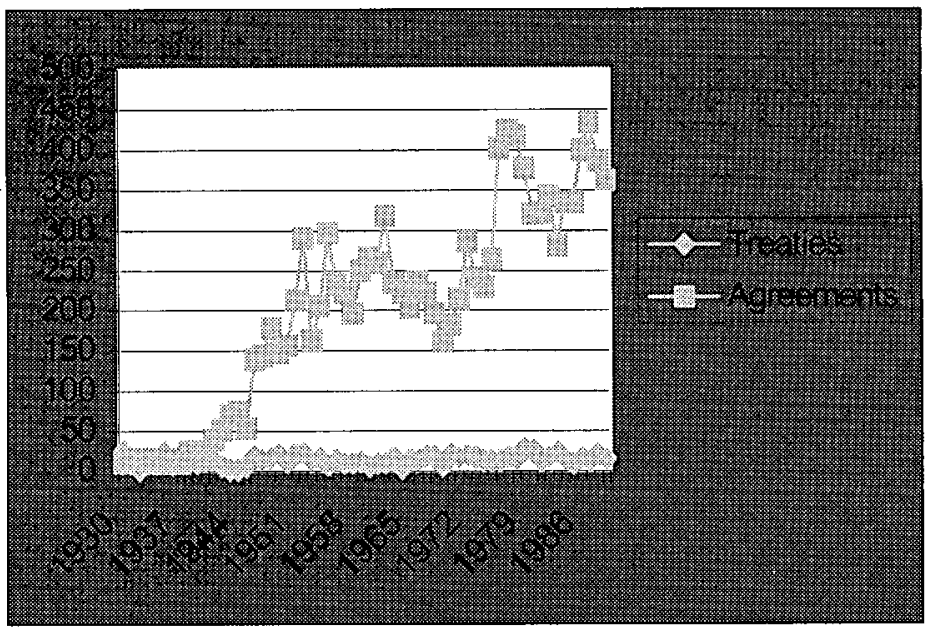

Source: Cong. Research Serv., 103D CONG., TREATIES AND OTHER INTERNATIONAL AGREEMENTS: THE ROLE OF THE UNITED STATES SENATE (Comm. Print 1993).

Treaties AND ExeCuTIVE AgReEMENTS CONCLUdED BY THE UNITED STATES, 1789-1989

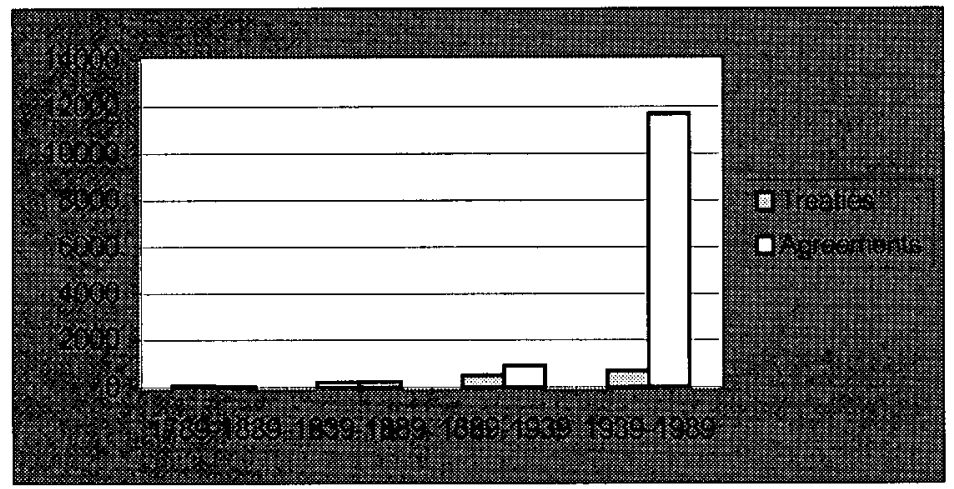

Source: CONG. ReSEARCH SERV., 103D CONG., TREATIES AND OTHER INTERNATIONAL AgREEMENTS: THE ROLE OF THE UNITED STATES SENATE (Comm. Print 1993) 
These numbers cannot be explained merely by the use of the congressional-executive agreement to engage in large numbers of minor international agreements. Rather, the political branches have resorted to the statutory process to make some of the nation's most important international commitments. In 1945, Congress approved by statute the Bretton Woods Agreement, which established two pillars of the postwar international economic system, the International Monetary Fund and the World Bank. ${ }^{29}$ Congress also approved by statute negotiating rounds of the GATT and the United States-Canadian Free Trade Agreement. ${ }^{30}$ Under the Clinton administration, approval of both NAFTA and the Uruguay Round that established the World Trade Organization took the same form. ${ }^{31}$ These agreements control matters that have effects on the United States as direct and as important as any treaty: they regulate the prices of goods, the operations of markets, and the conduct of governments and businesses. GATT and NAFTA do not just commit the United States to certain political or military courses of action; they primarily regulate economic activity of great importance to many private citizens. Expanding free trade has been one of the central themes of postwar American foreign policy, and the congressional-executive agreement has been its servant. ${ }^{32}$

\section{The Lack of Textual Support}

Given the important role played by the congressional-executive agreement, its lack of convincing textual or structural support ought to be a matter of great concern. The Constitution explicitly grants the federal government the power to make international agreements only in Article II, Section 2's Treaty Clause, and it refers to treaties only three other times. ${ }^{33}$ International legal scholars such as Professor Myres McDougal read an implicit authorization for nontreaty, international agreements in Article I, Section 10's prohibition upon states from entering into any "agreement or compact" with a foreign power. From this, they suggest that the Constitution recognizes a broader

29. Bretton Woods Agreements Act, Pub. L. No. 79-171, 59 Stat. 512 (1945).

30. United States-Canada Free-Trade Agreement Implementation Act of 1988, Pub. L. No. 100-449, 102 Stat. 1851 (codified as amended at 19 U.S.C. $\$ 2112(1994)$ ).

31. North American Free Trade Agreement Implementation Act, Pub. L. No. 103-182, 107 Stat. 2057 (1993) (codified at 19 U.S.C. $\$ \$ 3301$ et seq. (1994)); Uruguay Round Agreements Act, Pub. L. No. 103-465, 108 Stat. 4809 (1994) (codified at 19 U.S.C. \$§ 3501 et seq. (1994)).

32. For a recent discussion of the benefits of the expansion of free trade, see John $O$. McGinnis \& Mark C. Movsesian, The World Trade Constitution, 114 HARV. L. REV. 511 (2000).

33. See U.S. CONST. art. VI, $\$ 1$, cl. 2 (giving treaties supremacy over inconsistent state law); id. art. III, $\$ 2$, cl. 1 (providing that jurisdiction of federal courts may include treaties); $i d$. art. I, $\S 10$, cl. 1 (prohibiting states from entering into treaties). 
class of international agreements than just "treaties." Why would the Framers preclude the states from exercising the power to make an "agreement or compact," but then not give it to the federal government? ? $^{34}$

Constitutional silence, however, can cut both ways. The canon of expressio unius est exclusio alterius, by which the presence of one term implies the exclusion of others, suggests that the Framers understood all of the federal government's power to make international agreements to rest in the Treaty Clause. If the presence of the words "agreement or compact" in the text demonstrates that the Framers understood international agreements to take forms other than the treaty, then we can expect them to have used those words in Article II if they meant to grant a broader power to the national government. An examination of the original understanding shows no support for the idea that the Framers believed that the federal government possessed some free-floating, non-textual power to make international agreements. Rather, the attentions of both Federalists and AntiFederalists during the ratification debates focused exclusively on the Treaty Clause. ${ }^{35}$ Instead of worrying about whether statutes could do the job of treaties, the Framers argued over whether treaties might invade the province of statutes. ${ }^{36}$

Further, reading prohibitions on the states as empowering the federal government to do the opposite is an unpersuasive and ultimately dangerous interpretive technique. Section 2 of the Fourteenth Amendment, for example, prohibits states from denying citizens the equal protection of the laws. Adopting a McDougal-like approach would require us to infer the lack of a similar prohibition on the federal government as an implicit constitutional authorization to do otherwise. A similar interpretive approach would read the Fifteenth Amendment's prohibition on state efforts to block access to the ballot based on race as confirming the federal government's power to so discriminate. It does not appear that the Court would agree with these propositions,${ }^{37}$ nor would most constitutional theorists today.

One might suggest, as Professors Ackerman and Golove have, that the Necessary and Proper Clause provides Congress with the authority to make international agreements in aid of its other powers. ${ }^{38}$ In one of

34. See Myres S. McDougal \& Asher Lans, Treaties and Congressional-Executive or Presidential Agreements: Interchangeable Instruments of National Policy: I, 54 YALE L.J. 181, 203-06 (1945).

35. See Yoo, Globalism, supra note 8, at 2021-69.

36. See id.

37. See, e.g., Bolling v. Sharpe, 347 U.S. 497 (1954).

38. See Ackerman \& Golove, supra note 13 , at 811 . Professor Golove provides a more complete exegesis of this idea in his individual response to Professor Tribe. See David M. Golove, Against Free-Form Formalism, 73 N.Y.U. L. REV. 1791 (1998). 
their rhetorical moments, they characterize this as a "Marshallian" reading of the Constitution because it builds upon the approach of Chief Justice Marshall in $M c$ Culloch $v$. Maryland. ${ }^{39}$ As all law students learn, $M c C$ ulloch upheld the constitutionality of a national bank, even though it was nowhere mentioned in the constitutional text, because it was an appropriate means to achieve Congress's powers to regulate commerce, establish the treasury and currency, and fund government operations. Claiming to follow the same logic, defenders of the congressional-executive agreement claim that so long as Congress has decided that a congressional-executive agreement is "appropriate" to achieve the full use of a constitutional power, and so long as the "end [is] legitimate," 40 then the congressional-executive agreement is constitutional. While this argument better engages the textual problem, it suffers from several flaws. It incorrectly identifies constitutional meaning with Supreme Court decisions that limit the Court's own discretion in reviewing the constitutionality of legislation. $\mathrm{McC}$ ulloch's language about the link between ends and means serves the purpose of removing the Court from the job of reviewing legislative judgments. ${ }^{41}$ It does not relieve the President or Congress from determining whether certain means actually are constitutional, and it was on precisely this ground that President Jackson vetoed the bill chartering the Second Bank of the United States. ${ }^{42}$

A greater problem for this approach is that it misreads the federalism implications of $\mathrm{McCulloch}$ as authorization to alter the separation of powers. McCulloch's reading of the Necessary and Proper Clause only countenances expansions in federal powers, vis-à-vis the states, when necessary to achieve some legitimate federal aim. Recent cases, such as United States $v$. Printz, even indicate that state sovereignty may impose some limit upon the reach of the Clause. ${ }^{43}$ What is important to recognize, however, is that $M c$ Culloch does not allow Congress to deploy the Necessary and Proper Clause so as to rearrange the separation of powers. Reading the Necessary and Proper Clause to justify congressional-executive agreements causes separa-

39. 17 U.S. (4 Wheat.) 316 (1819).

40. Id. at 421 .

41. Indeed, in $\mathrm{McC}$ Culloch, the Court never really explains the fit between the national bank and the great constitutional ends it cites early in the opinion. See John Yoo, McCulloch v. Maryland, in Constitutional Stupidities, Constitutional TRAGEdies 241, 244 (William N. Eskridge, Jr. \& Sanford Levinson eds., 1998). For a narrow reading of the Clause, see Gary Lawson \& Patricia B. Granger, The "Proper" Scope of Federal Power: A Jurisdictional Interpretation of the Sweeping Clause, 43 DUKE L.J. 267 (1993).

42. See Andrew Jackson, Veto Message, July 10, 1832, in 3 MESSAGES AND PAPERS OF THE PRESIDENT 1139, 1145 (James D. Richardson ed., Bureau of Nat'l Literature 1917) (1897).

43. Printz v. United States, 521 U.S. 898 (1997) (invalidating federal law that commandeered state executives to carry out federal regulatory scheme). 
tion of powers problems because it transfers the power to make international agreements from the executive branch (made up of President and Senate) to the legislature. If this reading were correct, a variety of other congressional efforts to restructure government should have been equally constitutional. Congress, for example, could have used the Necessary and Proper Clause not just to condition the removal of an independent counsel so as to protect against interference in the investigation of high executive officials, but to shield completely the office from presidential control altogether. Congress could have relied upon the Clause to justify the creation of the legislative veto, or the vesting of budget reduction authority in the Comptroller General. Just as the Necessary and Proper Clause cannot infringe on the sovereignty of the states, so too it cannot be read to interfere with the core powers of the three branches. ${ }^{44}$ While it may be very well to read the Clause as allowing a power to establish a national bank where none had been granted to the federal government, it is quite a different matter to read the Clause as allowing Congress to seize from the President and Senate the power to make international agreements.

\section{Interchangeability with Treaties}

Despite the paucity of textual support, the congressional-executive agreement has come to provide for many a complete alternative to the treaty. According to the Restatement (Third) of the Foreign Relations Law of the United States, "[t]he prevailing view is that the Congressional-Executive agreement can be used as an alternative to the treaty method in every instance." 45 As the Restatement explains, the government has resorted to the statutory method to make agreements on a wide variety of subjects. None has ever been successfully challenged in court on constitutional grounds. Since there is no line between the two instruments, "[w]hich procedure should be used is a political judgment, made in the first instance by the President." 46 Although he recognizes the difficult constitutional issues surrounding interchangeability, Professor Henkin accepts that the congressional-executive agreement may serve as a complete substitute for a treaty. He even encourages their expanded use should the Senate oppose internationalism: such agreements, he advises, "remain[] available to Presidents for wide, even general use should the treaty process again provide difficult." ${ }^{47}$ In other words, any matter upon which the President and Senate can make a treaty is fair game for a congressional-executive

44. See, e.g., Steven G. Calabresi \& Saikrishna B. Prakash, The President's Power to Execute the Laws, 104 YALE L.J. 541, 590-92, 622-26 (1994).

45. RESTATEMENT (THIRD), supra note 7 , at $\S 303 \mathrm{cmt}$. e.

46. Id.

47. HENKIN, FOREIGN AFFAIRS, supra note 6, at 218. 
agreement. ${ }^{48}$ Most scholars in foreign relations law to write on the subject, ${ }^{49}$ as well as members of the executive branch, ${ }^{50}$ and even advisers to Congress ${ }^{51}$ seem to agree with this conclusion.

Under this doctrine of interchangeability, congressional-executive agreements apparently receive all of the benefits that accrue to treaties. Congressional-executive agreements, for example, are not restricted by any subject matter limitations. According to standard internationalist thought, the President and Senate may resort to the treaty process to address any matter, so long as it is "an agreement between two or more states or international organizations that is intended to be legally binding and is governed by international law." 52 If treaties enjoy this broad scope, then, so too, must congressionalexecutive agreements. Similar logic suggests that congressionalexecutive agreements will not encounter the same separation of powers and federalism restrictions that apply to statutes, because treaties are exempt from many of these limitations. Both treaties and congressional-executive agreements bind the United States in the same way and with the same permanence under international law. President Truman summarized the consensus view in discussing whether to use a treaty or a statute for the agreement for the Trust Territory of the Pacific Islands. "I am satisfied that either method is constitutionally permissible and that the agreement resulting will be of the same effect internationally and under the supremacy clause of the Constitution

48. While the Restatement (Third) appears to limit congressional-executive agreements to "any matter that falls within the powers of Congress and of the President under the Constitution," RESTATEMENT (THIRD), supra note 7, at $\$ 303(2)$, it is unclear how far this restraint goes, given that foreign relations scholars believe that the federal foreign affairs power includes the power to legislate on any subject that could arise between the United States and a foreign nation. See Louis Henkin, The Treaty Makers and the Law Makers: The Law of the Land and Foreign Relations, 107 U. PA. L. REV. 903, 905 (1959).

49. See, e.g., Solomon Slonim, Congressional-Executive Agreements, 14 CoLUM. J. Transnat'L L. 434 (1975); Philip R. Trimble \& Alexander W. Koff, All Fall Down: The Treaty Power in the Clinton Administration, 16 BERKELEY J. INT'L L. 55 (1998); Trimble \& Weiss, supra note 6, at 650-53; Armen R. Vartian, Approval of SALT Agreements by Joint Resolution of Congress, 21 HARV. INT'L L.J. 421 (1980).

50. See, e.g., Monroe Leigh, Department of State Legal Adviser's Reply to Senate Office of Legislative Counsel Memorandum on Certain Middle East Agreements, 121 CONG. REC. 36,718 (1975).

51. See SENATE 1993 REPORT, supra 5, at 58-59.

52. RESTATEMENT (THIRD), supra note 7, at § 301(a); see also Lori F. Damrosch, The Role of the United States Senate Concerning "Self-Executing" and "Non-Self-Executing" Treaties, 67 CHI.-KENT L. REV. 515, 530 (1991); see also HENKIN, FOREIGN AFFAIRS, supra note 6, at 197; Gerald L. Neuman, The Global Dimensions of RFRA, 14 CONST. COMMENT. $33,34,46-47$ (1997). According to Henkin, "[i]f there are reasons in foreign policy why the United States seeks an agreement with a foreign country, it does not matter that the subject is otherwise 'internal', that the treaty 'makes laws for the people of the United States in their internal concerns', or that - apart from treaty - the matter is 'normally and appropriately ... within the local jurisdictions of the States." HENKIN, FOREIGN AFFAIRS, supra note 6 , at 197 . 
whether advised and consented to by the Senate or whether approval is authorized by a joint resolution." 53

\section{B. The Defects of Interchangeability}

The increasing use of the congressional-executive agreement is ironic. Just as it has assumed a central role in the conduct of American foreign policy, the justification for its constitutionality appears to rest on increasingly shaky foundations. Prominent constitutional scholars recently have attacked this alternative method for making international agreements. Indeed, the leading defense of the constitutionality of the NAFTA and WTO agreements expressly relies upon a theory of non-textual constitutional amendments. This Part will begin by discussing and evaluating the internationalist defense of the statutory procedure, and then detailing recent scholarly controversy over its constitutionality as a substitute for the treaty. It will describe the new defense of congressional-executive agreements offered by Professors Ackerman and Golove, and Professor Tribe's response to their views. It will explain why neither approach proves satisfactory and why each is subject to crippling doubts.

\section{The Internationalist View and Its Defects}

As Professors Ackerman and Golove document in their detailed history of the intellectual origins of the congressional-executive agreement, the idea of using ex post congressional approval of presidentially negotiated international agreements did not take firm root until the World War II period. At that time, several prominent scholars, among them Edwin Corwin, ${ }^{54}$ Quincy Wright, ${ }^{55}$ and Myres McDougal and Asher Lans, ${ }^{56}$ argued that such a procedure might substitute for the treaty process. Without adopting the notion that these legal intellectuals helped spark a constitutional moment, much in the same way that one always needs the intelligentsia to help along the Russian Revolution, it is worth examining their arguments because they still have currency today. Their views are also worth further consideration because they continue to form the basis for the acceptance of congressional-executive agreements by leading authorities such as Professor Henkin and the Restatement.

53. Message of the President of the United States to Congress, H.R. DoC. No. 80-378, at 2

54. EDWIN S. CORWIN, THE CONSTITUTION AND WORLd ORganization (1944).

55. Quincy Wright, The United States and International Agreements, 38 AM. J. INT'L L. 341 (1944).

56. McDougal \& Lans, supra note 34. 
Initially, internationalist scholars built their case on precedent. They pointed to a long line of examples, beginning with the first congressional authorization of international postal agreements, continuing through the annexations of Hawaii and Texas, and including various reciprocal trade laws, that allegedly demonstrated almost 200 years of interchangeability. Part II will examine the practice of the political branches, but suffice it to say at this point that none of these precedents evidenced a decision to replace the treaty with a statutory process in which Congress gives its ex post consent to a presidentially negotiated agreement. Rather, many of these examples fall within the other types of interbranch cooperation - sometimes erroneously conflated with the distinct type of congressional-executive agreement addressed here - in which Congress essentially delegates factfinding or rulemaking authority to the President. ${ }^{57}$

Defenders of the constitutionality of congressional-executive agreements have claimed that two Supreme Court cases, Field v. Clark ${ }^{58}$ and B. Altman \& Co. v. United States,${ }^{59}$ provide legitimacy for the practice of interchangeability. Closer examination of these cases, however, demonstrates that they lend little support for the idea that statutes could substitute for treaties.$^{60}$ In Field v. Clark, the plaintiff argued that Congress could not delegate to the President factfinding authority for a reciprocal tariff law. As mentioned earlier, however, this type of arrangement is a very different creature from the ex post congressional-executive agreement of today, and, in fact, it does not even require an agreement with another nation. ${ }^{61}$ Field v. Clark only rejected the claim that the reciprocal tariff statute violated the nondelegation doctrine, and nothing more. It could not find that the ex post congressional-executive agreement was constitutional because there was no such congressional-executive agreement involved. ${ }^{62}$

$B$. Altman similarly did not call upon the Court to review the constitutionality of a statutory method for making international agreements. The case involved a different kind of mechanism, in which Congress provided the President with ex ante authorization to reach trade agreements, within specified criteria, with different nations. Further, $B$. Altman did not raise the question of the constitutionality of the use of this procedure in place of the treaty. Instead, it asked only

57. See supra text accompanying note 24 .

58. 143 U.S. 649 (1892).

59. 224 U.S. 583 (1912).

60. See Ackerman \& Golove, supra note 13 , at $830-32$.

61. See supra text accompanying note 24 .

62. The Court also rejected, in one sentence, the argument that the tariff statute had unconstitutionally vested the President alone with the treaty power. See Field, 143 U.S. at 694. 
whether a statute that provided the Court with appellate review over claims based upon "treaties," could be read to include this novel form of executive and legislative cooperation. The Court read the statute broadly to include not just a "treaty possessing the dignity of one requiring ratification by the Senate of the United States," ${ }^{63}$ but also a congressionally authorized executive agreement that rose to the level of an "international compact." ${ }^{64}$ As others have recognized, $B$. Altman did not come close to passing on the question of the interchangeability of congressional-executive agreements and treaties for constitutional purposes. ${ }^{65}$

Once we dispel the notion that the congressional-executive agreement has received the approval of historical practice or judicial decision, the genuine reason for its modern use comes into focus. Congressional-executive agreements represented an effort to replace what was seen as an outmoded method for dealing with international affairs, one established in a world of sailing ships, horse-borne couriers, and muskets, with a more efficient, democratic process. New Deal legal scholars and their progeny believed that providing the Senate with a checking role in making international agreements had been a dismal failure. Functionally, the Senate had never assumed the co-equal role in international negotiations that the Framers had hoped for. ${ }^{66}$. The Senate's formal role in treatymaking had become one of after-the-fact consent, while the President assumed primary responsibility for setting foreign policy and conducting diplomatic negotiations. Vesting the treaty power partially in the Senate to achieve secrecy and speed no longer seemed compelling, due to the large size of the Senate, the role of the House in foreign affairs, and the nature of modern treaties, which no longer demanded such secrecy.

Defects in the Senate's role did not rest just in process. Giving the states a checking role in foreign affairs had led to results that harmed the national interest. With only a small minority needed to block an international agreement, the treaty process allowed isolationism to reign over American foreign policy. ${ }^{67}$ Some even suspected that states

63. B. Altman, 224 U.S. at 601.

64. Id.

65. See Ackerman \& Golove, supra note 13, at 831.

66. See Stanley ElKins \& ERIC MCKITRICK, The Age of Federalism 55-58 (1993) (describing President Washington's failed attempt to consult with the first Senate on treaties). Apparently, when President Washington appeared in the Senate, the noise and confusion led to the treaty matter being deferred to another day. President Washington left in a huff and, according to one story, declared that "he would be damned if he ever went there again." Id. at 55.

67. As Professor Henkin has written, "By permitting approval of an agreement by simple majority of both houses, it eliminates the 'veto' by one-third-plus-one of the Senators present which in past had effectively buried important treaties." HENKIN, FOREIGN AFFAIRS, supra note 6, at 217. 
would use their voice in the treaty process to win regional or sectional advantages. Sectional controversy, they asserted, originally had forced the Framers to create the two-thirds requirement for senatorial approval in the first place. ${ }^{68}$ While some might argue that the constitutional difficulty in making treaties expressed the Framers' bias against international entanglements, the New Deal authors believed that isolationism was simply a disease that threatened to cripple America in a new, interdependent world. Isolationist Senators, after all, had blocked American participation in the League of Nations, to which they attributed the failure of the peace, the rise of Hitler, and the return of world war. New Deal scholars believed that a small minority of Senators should not be able to use the Constitution to foist their isolationist preferences upon the majority's desire for more engagement in the world. Adopting a congressional procedure, without a supermajority, would rid isolationism of its chokehold over American foreign policy.

Building on this previous point, internationalist scholars believed that the congressional-executive agreement substituted a more democratic mechanism for a state-dominated process. As Professor Henkin has suggested, "[o]ne way of rendering treaty making more democratic without constitutional amendment might be to have agreements made by the President if authorized or approved by both houses of Congress," which would serve "the cause of greater democracy." 69 International agreements reached through a statutory process reflect the will of the majoritarian President and of both houses of Congress. Internationalist scholars believe approval by the most democratic branches to be particularly important for new types of international agreements. These agreements were just as significant to the nation's welfare as any domestic legislation, and with national economies and societies becoming more interdependent, they would have a direct impact on the everyday domestic lives of Americans. ${ }^{70}$ The congressional-executive agreement better promotes democratic government by requiring the consent of the most democratic part of the government, the House of Representatives, before the nation undertakes international obligations that so directly affect the people.

68. For a discussion of the historical roots of this argument, see Yoo, Globalism, supra note 8, at 2061-64. See also FORREST MCDONALD, WE THE PEOPLE: THE ECONOMIC ORIGINS OF THE CONSTITUTION 259, 268, 366-67 (1958); Charles Warren, The Mississippi River and the Treaty Clause of the Constitution, 2 GEO. WASH. L. REV. 271, 282-85, 296-97 (1934).

69. Louis Henkin, Constitutionalism, Democracy, And Foreign AFFairs 60 (1990) [hereinafter HENKIN, CONSTITUTIONALISM].

70. Congressional-executive agreements also simplified the process of making international agreements by combining the international agreement with the implementing legislation that usually is required to bring it into effect in domestic law. 
These criticisms of the treaty process no doubt have substantial truth to them. It is clear from the historical evidence that the Framers understood that the treaty process would be anti-democratic. ${ }^{71} \mathrm{~A}$ desire for greater democracy, however, standing alone does not provide sufficient reason for reading a clear textual provision out of the Constitution. The same arguments that internationalist scholars levied against the Senate's role in treatymaking easily could be repeated against many other features of the Constitution. Take the Senate's institutional role generally. States representing a minority of the population can block treaties; states representing a minority of the population can block normal legislation as well. ${ }^{72}$ Senators representing a minority of the population can block the appointment of cabinet officers and federal judges. Senators representing a minority of the states can block constitutional amendments, as can an even smaller minority of state legislatures. Or take the Supreme Court's power of judicial review, which is not even explicitly granted in the Constitution. Every time the Court invalidates a federal law, a small number of unelected officials have prevented the majority from acting. Do these antidemocratic features demand that the political branches devise nontext-based methods for their evasion $?^{73}$

Indeed, the weakness of the internationalist defense of congressional-executive agreements is further revealed by an unwillingness to take the pro-majoritarian case to its logical conclusion. If the objective is to increase the democratic nature of making international agreements, internationalists provide no reason to stop with a statutory process. Even the constitutionally prescribed method for making laws suffers from antimajoritarian features. ${ }^{74}$ Senators from the least populous states can block a statute supported by the majority; an even smaller number can use the filibuster to prevent even a majority of Senators from voting; committee chairs and majority leaders can impose their wishes at variance with that of the majority; interest groups may succeed in manipulating the legislative process to engage in rent-seeking. If internationalist scholars pursued their quest for democracy full bore, they ought to seek to centralize all international agreement making in the President alone, who (along with the Vice-President) is

71. See Yoo, Globalism, supra note 8, at 2024-74.

72. See Yoo, Non-Self-Execution, supra note 10, at 2240 n.79 ("According to 1998 population estimates, two-thirds of the Senate can represent as little as 32 percent of the population.").

73. Cf. Henry P. Monaghan, We the People[s], Original Understanding, and Constitutional Amendment, 96 COLUM. L. REV. 121, 165-173 (1996) (criticizing recent theories of majoritarian amendments to the Constitution for ignoring antidemocratic features of the Constitution).

74. See, e.g., JESSE H. CHOPER, Judicial REVIEW AND THE NATIONAL POLITICAL PROCESS: A FUNCTIONAL RECONSIDERATION OF THE ROLE OF THE SUPREME COURT 1225 (1980) (describing the "defective character" of Congress's majoritarianism). 
the only federal official elected by the entire electorate. ${ }^{75}$ Instead, leading international law academics have criticized the expansion in presidential power that has allowed for sole executive agreements. ${ }^{76}$ While Presidents currently enjoy the authority to make sole executive agreements in areas within their plenary constitutional powers, and while those agreements may even trump inconsistent state law, ${ }^{77}$ their executive power in foreign affairs has never been read to include the authority to make any and all international agreements, regardless of their subject matter or nature.

Such an argument obviously conflicts with the text and structure of the Constitution. This approach not only would read the text of the Treaty Clause out of the Constitution, it also would allow the President to encroach on Congress's Article I, Section 8 powers in foreign affairs, such as the regulation of international commerce. Internationalists have sharply criticized such theories of executive dominance in foreign affairs when they have arisen elsewhere in cases such as United States v. Curtiss-Wright Export Corp ${ }^{78}$ If it were acceptable, however, to allow statutes to replace the Treaty Clause as a method for making international agreements, despite the Constitution's sole mention of the federal government's power to do so in Article II, Section 2, then it would be equally legitimate to allow unilateral presidential decree to replace the congressional-executive agreement. Perhaps, in the internationalists' defense, one might say that the statutory process still ensures that some form of checks and balances exists in the making of international agreements. Maintaining checks and balances, though, does not explain why the congressional-executive agreement is to be preferred to the treaty process; the treaty process itself contains both checks and balances and a majoritarian element through the participation of the President. Making the Constitution more majoritarian includes no principle to limit its application.

75. In fact, one of the earliest defenders of the congressional-executive agreement, Wallace McClure, made precisely this argument. McClure believed that the President on his sole authority could make any international agreement, so long as it was not disapproved by Congress. See WALlaCe MCCluRE, InTERNATIONAL EXECUTIVE AGREEMENTS: DEMOCRATIC PROCEDURE UNDER THE CONSTITUTION OF THE UNITED STATES 363 (AMS Press 1967) (1941). 45.

76. See HENKIN, FOREIGN AFFAIRS, supra note 6, at 221-24; KoH, supra note 6, at 44 -

77. See, e.g., United States v. Pink, 315 U.S. 203 (1942); United States v. Belmont, 301 U.S. 324 (1937).

78. 299 U.S. 304 (1936). See Henkin, Constitutionalism, supra note 69, at 17-43; $\mathrm{KOH}$, supra note 6, at 134-46, 208-12. 


\section{The Transformationist Effort at Rehabilitation and Its Faults}

While internationalists prefer to see a gradual evolution from the treaty to the congressional-executive agreement, another group of academics arrive at the same destination by a different, jagged path. In order for treaties and statutes to have the same status, they argue that in 1945 the American people rejected the legitimacy of the Senate's supermajority role in favor of a statutory process for making international agreements. I call this the transformationist school because its theorists, Professors Ackerman and Golove, maintain that "We the People" have amended the Constitution - even though no formal constitutional amendment ever underwent the ratification process so as to allow the United States to incur any international obligation by congressional-executive agreement. In their minds, political struggle over the treaty power during the birth of the postwar world order amounted to a non-textual constitutional change that eliminated the exclusivity of the Treaty Clause. This Section will discuss several problems - textual, interpretive, and historical - that afflict the transformationist account and undermine its defense of interchangeability.

Transformationists rely upon practice to support their conclusion that such instruments should enjoy the same status as treaties. They emphasize the use of the congressional-executive agreement in the construction of the international financial and trade systems, and they seek justification in the manner in which use of the congressionalexecutive agreement has outpaced the treaty. As the numbers suggest, the congressional-executive agreement did not appear by accident. Instead, Professors Ackerman and Golove argue that a group of professors and government officials, scarred by the Senate's refusal to approve the Versailles Treaty, waged an intellectual campaign before and during World War II to make congressional-executive agreements interchangeable with treaties. ${ }^{79}$ Transformationists believe, however, that neither scholarly opinion nor political practice before World War II supported the interchangeability of statutes and treaties. Rather, they conclude that the New Deal scholars misread precedent and made blatant appeals to policy in order to set the stage for the mothballing of the treaty process. Building on elite opinion, the centrally important event in legitimating the congressional-executive agreement occurred in the 1944 elections, in which the American people allegedly lent their overwhelming approval to the re-election of President Franklin D. Roosevelt and his postwar plans for intensive participation in international institutions. Opinion polls and newspaper editorials at the time, according to Ackerman and Golove, indicate that the

79. See Ackerman \& Golove, supra note 13 , at $861-73$. 
electorate supported the elimination of the Senate's chokehold over treaties as part of a groundswell against isolationism.

The most nagging flaw with the transformationist position, as with the internationalist approach, is that it essentially reads the Treaty Clause out of the Constitution. If congressional-executive agreements are fully interchangeable with treaties, and if congressional-executive agreements are not mentioned in the Constitution while treaties are, then the New Deal internationalists are guilty of amending the Constitution without resort to the Article $\mathrm{V}$ process. Responding to this challenge, made most forcefully by Professor Laurence Tribe against the constitutionality of the congressional-executive agreements approving NAFTA and the Uruguay Round, ${ }^{80}$ Ackerman and Golove invoke Ackerman's controversial theory of amending the Constitution outside of Article V.$^{81}$ Ackerman and Golove believe that the Constitution provides for two types of lawmaking: higher/constitutional lawmaking and ordinary/political lawmaking. The latter occurs most of the time, when people make ordinary policy through regular elections. The former occurs at revolutionary "moments," when the citizenry becomes consumed with more profound constitutional and political issues, debates them, and resolves them in ways that fundamentally alter the nature of constitutional government. ${ }^{82}$

Ackerman and Golove view the adoption of the congressionalexecutive agreement as another episode in one of these moments, the New Deal. As the end of World War II neared, intellectual and political leaders sought to avoid a repeat of Versailles by engaging in an end run around the treaty's supermajoritarian requirement. According to Ackerman and Golove, overwhelming popular majorities agreed with elite internationalist opinion to replace the treaty with a more democratic process. Transformationists view the 1944 triumph of Roosevelt and the Democratic Party as legitimating the substitution of the prointernationalist congressional-executive agreement for the treaty. With public opinion polls in favor of a two-house process for international agreements, ${ }^{83}$ and in the face of proposed constitutional amendments in the House to strip the Senate of its monopoly over the treaty power, the Senate backed down. Its agreement to the statutes approving the Bretton Woods agreements, according to Ackerman and Golove, signified the Senate's acquiescence to a new constitu-

80. See generally Tribe, supra note 14.

81. See Ackerman \& Golove, supra note 13, at 873-75.

82. For a fuller elaboration of the thesis, see ACKERMAN, WE THE PEOPLE: Foundations, supra note 13; ACKERMAN, WE THE PEOPLE: TRANSFORMATIONS, supra note 13.

83. In May $1944,60 \%$ of the public favored an ordinary two-house process for international agreements, while only $19 \%$ continued to support the traditional treaty method. See Ackerman \& Golove, supra note 13, at 863. 
tional settlement. ${ }^{84}$ By 1947, "[i]nterchangeability had become part of the living Constitution," 85 and it was firmly "codified" in the 1950s, 1960 s, and 1970s. This became part of the larger constitutional change wrought by the New Deal, which transferred power from the states to the national government and from Congress to the administrative state. Similarly, the internationalist victory produced more populist lawmaking in foreign affairs by removing the anachronistic ability of a minority of the states, through their votes in the Senate, to keep the nation on an isolationist path. ${ }^{86}$ Rather than evolution, the move to the congressional-executive agreement was a sharp, and quite conscious, break from the past.

While certainly colorful and provocative, the transformationist argument suffers from a number of terminal defects. First, it bears the same defects that afflict Ackerman's general theory of constitutional interpretation. ${ }^{87}$ While this is not the place to engage in a full-scale critique of the "constitutional moments" theory, some of the main points may be summarized here. There is little doubt that the Framers conceived of constitutional lawmaking as distinct from ordinary lawmaking, but Ackerman provides little evidence that the Framers believed higher lawmaking could occur outside of Article V, but within the normal constitutional framework. If the people were to act outside of Article $\mathrm{V}$, they would be altering and abolishing their previous form of government completely, rather than making minor adjustments. ${ }^{88}$ To

84. See id. at $890-93$.

85. Id. at 896 .

86. Ackerman and Golove are worth quoting in detail on this point.

Just as New Deal scholars attacked the antimajoritarian character of the Old Court, now the New Internationalists attacked the antidemocratic veto granted the malapportioned Senate. Just as New Deal scholars mined the history of the Marshall Court to create a pedigree for a newly expanded Commerce Clause, now the New Internationalists scavenged for precedents that helped expand the scope of Article I yet further to support congressional-executive agreements. The point of both exercises was the same: to convince legalists that the constitutional tradition applauded the collective effort to correct the anachronistic formalisms of the past when modern Americans were demanding fundamental change.

Id. at 911 .

87. For penetrating criticism of the Ackerman thesis and its variants, see, for example, Tribe, supra note 14, at 1228-49; Michael J. Gerhardt, Ackermania: The Quest for a Common Law of Higher Lawmaking, 40 WM. \& MARY L. REV. 1731 (1999) (book review); Michael Klarman, Constitutional Fact/Constitution Fiction: A Critique of Bruce Ackerman's Theory of Constitutional Moments, 44 STAN. L. REV. 759 (1992) (book review); Suzanna Sherry, The Ghost of Liberalism Past, 105 HARV. L. REv. 918 (1992) (book review).

Ackerman's thesis has received praise from some scholars. See, e.g., Sanford Levinson, Accounting for Constitutional Change, 8 CONST. COMMENT. 409, 429 (1991); James Gray Pope, Republican Moments: The Role of Direct Popular Power in the American Constitutional Order, 139 U. PA. L. REV. 287, 304 (1990); Mark Tushnet, The Flag-Burning Episode: An Essay on the Constitution, 61 U. COLO. L. REV. 39, 48-53 (1990).

88. I have argued elsewhere that the Framers understood the right to abolish and alter government as one of the unenumerated majoritarian rights. See John Choon Yoo, Our Declaratory Ninth Amendment, 42 EMORY L.J. 967, 970-99 (1993). 
act within the framework of the Constitution, amenders must include a text that can identify exactly what supermajorities of the people have agreed to change in the Constitution, and whether permanent supermajorities on the question indeed exist. Both the Framing and Reconstruction are distinct from 1944 in that the first two constitutional moments resulted in formal amendments that embodied the revolutions that occurred, while the New Deal and the 1944 moment did not. If popular support were indeed as overwhelming as transformationists believe for the congressional-executive agreement, its supporters should have guaranteed its future legitimacy by ratifying a constitutional amendment. Legal instruments, such as statutes or constitutional amendments, allow the polity itself to judge whether large, inchoate majorities will translate into concrete changes in social and political norms. Indeed, without the text of an amendment, it is difficult if not impossible for later interpreters to determine what changes the majority actually understood it was making in the governing structure and how long-lasting they would be.

Second, even accepting that constitutional change may legitimately occur outside the context of a formal amendment, Ackerman provides no sure way to identify when an amendment-less constitutional moment has occurred. ${ }^{89}$ If periodic elections are the product of lesser, sordid, ordinary political lawmaking, it seems contradictory to assert that they also can reflect higher lawmaking, unless accompanied by a constitutional amendment. To take the 1944 elections, for example, Ackerman and Golove are forced to assume that voters actually had the congressional-executive agreement issue in mind when they voted for the Democratic Party or for President Franklin D. Roosevelt for the fourth time. But voters had any number of issues on their minds during the 1944 elections: Roosevelt's enormous personal popularity, maintaining political stability during the endgame of the war, dislike of the Republican presidential candidate, Governor Thomas Dewey (who was so uninspiring a candidate that contemporaries compared him to "the bridegroom on the wedding cake, the only man who could strut sitting down, a man you really had to know to dislike, the Boy Orator of the Platitude"), ${ }^{90}$ and approval of the Democratic administration's wartime policies.

Ackerman and Golove's defense of interchangeability, in other words, suffers from a level-of-generality problem. FDR and the Democrats certainly won the 1944 elections, and it seems safe to conclude that the Democrats' more internationalist approach to the postwar order had something to do with it. Ackerman and Golove, however, provide no compelling reason why we must interpret general

89. See Sherry, supra note 87 , at 929-34.

90. JAmes MaCGregor Burns, RoOSEVElT: The Soldier of Freedom 502 (1970). 
political approval for the Democrats and distaste for the Republicans to be the mandate for a constitutional amendment on the far narrower issue of congressional-executive agreements. They fail to point to any significant campaign speeches or statements where FDR or Dewey mentioned interchangeability, congressional-executive agreements, or the Senate's constitutional role in treatymaking; they do not identify any facts that show that the electorate was conscious of the constitutional difficulties created by the Senate's supermajoritarian check; nor do they demonstrate that party leaders believed this to be a significant issue in the campaign. Instead, Ackerman and Golove are left to infer that, because the electorate wanted a more secure, internationalist postwar order, they would have agreed to lesser-included measures to achieve that goal, such as interchangeability. Historians of the period have reviewed the same evidence and have not reached similar conclusions. Indeed, while a recent work by historians Townsend Hoopes and Douglas Brinkley recognizes the 1944 electoral results as "a clearcut mandate for American participation in the United Nations and for a large American role in the postwar world," they also point out that Roosevelt had won by only three million votes, the tightest margin of victory since 1916 and a reflection of concerns about FDR's health and long term in office. ${ }^{91}$ The 1944 elections provided a vague mandate for internationalism, but nothing more concrete or defined.

To be sure, Ackerman and Golove raise several historical facts that they believe show this link between the 1944 elections and the alleged constitutional moment. They point, for example, to 1944 opinion polls, newspaper editorials, and proposed constitutional amendments in the House that all supported stripping the Senate of its exclusive power over international agreements. They then claim that the House withdrew proposals to achieve this result in exchange for approval of the Bretton Woods agreements by statute. Yet, Ackerman and Golove encounter severe difficulties in showing the necessary linkages that would indicate a constitutional moment: a) party leaders chose to make the 1944 elections a referendum on the Senate's treatymaking role; b) the electorate understood the 1944 elections to embody this choice; c) the President and the House intended to force the Senate to give up its role; d) the Senate understood itself to be accepting interchangeability in allowing the Bretton Woods agreements.

In order to show that these events all occurred and were interlinked, Ackerman and Golove are forced to rest their argument upon some very slim reeds indeed. One glaring example is that they make much hay out of small differences in the wordings of the platforms of the political parties (one mentions "treaty or agreement," the other only "agreements and arrangements"), in order to claim a real differ-

91. TOWNSEND HoOPES \& DOUGLAS BRINKLEY, FDR AND THE CREATION OF THE U.N. 164 (1997). 
ence between the parties concerning the interchangeability of congressional-executive agreements and treaties. ${ }^{92}$ Only by finding a difference between the parties can they claim that the 1944 elections demonstrated any choice of constitutional instruments. Yet they do not show that political leaders or the voters understood this difference in language to signify sharply divergent positions, if any, on interchangeability. Similarly, Ackerman and Golove believe that the timing of the passage of the Bretton Woods agreement by statute, coming as it did after the House considered a proposal to amend the treaty power, evidenced the Senate's acceptance of the "deal" for interchangeability. ${ }^{93}$ Yet they can show no historical evidence that any significant actor in the passage of Bretton Woods or of the United Nations Charter, which came shortly thereafter, understood these agreements to represent a constitutional settlement of any sort.

As an interpretive matter, none of these facts standing alone provides historical support for the notion that the voters in 1944 or their elected representatives undertook to engage the nation in a constitutional revolution on a par with the Framing or Reconstruction. Newspapers editorialize and popular opinion polls register on any number of issues that never translate into constitutional amendments. Any number of proposed amendments never make it into the Constitution. One can never be sure whether these imperfect, and temporary, signals of popular preferences actually amount to the permanent support for a change in the written Constitution unless they actually meet the test for one: approval by two-thirds of the House and Senate and three-quarters of the states. Indeed, Ackerman and Golove cannot show that proposals to eliminate the Senate's monopoly over the treaty power ever had this support, because none ever came to a vote in both houses of Congress. ${ }^{94}$

The transformationist account further stumbles upon the very primary source history from which it draws its strength. It is dubious, for example, whether the 1944 elections and the passage of the Bretton Woods agreements serve as convincing evidence of a constitutional moment. While the 1944 elections may have provided support for a more internationalist foreign policy, it does not appear that any of the major political leaders viewed the election results as a mandate to do away with the treaty. Neither Roosevelt nor Dewey engaged in any se-

92. See Ackerman \& Golove, supra note 13 , at $884-85$.

93. See id. at $891-92$

94. While one amendment to strip the Senate of its exclusive treaty powers passed the House by 288 to 88,91 CONG. REC. $4367-68$ (1945), these proposals never came to a vote in the Senate. Ackerman and Golove present no explanation concerning the votes in the House; were the Members of the House serious? Was this part of a concerted campaign to strip the Senate of its authority? Or was this vote symbolic, meant only to show that the House was doing something about international agreements? 
rious debate or discussion during the campaign about the shape of the postwar world or the United Nations - in fact, the presidential candidates had negotiated a truce to keep the question of international organization out of the wartime elections. ${ }^{95}$ Franklin Roosevelt's campaign activity during the summer and fall of 1944 shows no mention of the Senate's treaty role or of congressional-executive agreements. ${ }^{96}$ In his most significant speech concerning foreign affairs during the election, President Roosevelt only saw fit to discuss broad policy differences with the Republican Party - namely his claims that Republicans had always championed isolationism - rather than process issues like the Senate's power over treaties. ${ }^{97}$

Evidence is similarly absent concerning the approval of the Bretton Woods and U.N. Charter agreements. President Truman's memoirs do not discuss any constitutional deal, nor even the issue of the interchangeability of congressional-executive agreements. Dean Acheson, who at the time was Assistant Secretary of State for congressional relations, never mentions the issue in his detailed account of the period. ${ }^{98}$ It does not appear that either Senators or Members of the House understood the passage of Bretton Woods to impart any meanings of constitutional significance. While Ackerman and Golove rely upon statements in the congressional record, committee reports, and the occasional campaign speech or party platform, they do not place these records in the context provided by numerous available primary sources, such as the Foreign Relations of the United States series, presidential library materials, memoirs, and oral histories - all standard sources for diplomatic and presidential historians of the origins of the Cold War.

Ackerman and Golove further fail to rely upon, or even cite, any secondary historical and political science works about the period. Such sources reveal that their reading of the construction of the postwar world has little support in the mainstream historical accounts. Standard biographies of FDR, both old and new, do not mention interchangeability, congressional-executive agreements, or the Senate's

95. See HOOPES \& BRINKLEY, supra note 91, at 162.

96. See, e.g., Franklin D. Roosevelt, Address at Dinner of International Brotherhood of Teamsters, Chauffeurs, Warehousemen and Helpers of America (Sept. 23, 1944), in THE Public PAPERS AND AdDRESSES OF FRANKLIN D. ROOSEVElT, 1944-45 Volume: VICTORY AND THE THRESHOLD OF PEACE 284 (Samuel I. Rosenman ed., 1950); Franklin D. Roosevelt, Radio Address at Dinner of Foreign Policy Association (Oct. 21, 1944), in id. at 342 [hereinafter Roosevelt, Radio Address at Dinner of Foreign Policy Association]. 96.

97. See Roosevelt, Radio Address at Dinner of Foreign Policy Association, supra note

98. See Dean acheson, Present at the Creation: My Years in the State DEPARTMENT 104-15 (1969). Secondary sources on Acheson's role likewise are silent about interchangeability and congressional-executive agreements. See, e.g., JAMES CHACE, ACHESON: THE SECRETARy OF STATE Who CREATEd THE AMERICAN World 97-109 (1998). 
role in treatymaking in the context of the 1944 elections. ${ }^{99}$ More specialized works on Franklin Roosevelt and foreign policy, such as Robert Dallek's standard Franklin D. Roosevelt and American Foreign Policy, 1932-1945, ${ }^{100}$ and more recent studies, ${ }^{101}$ make no mention of interchangeability - indicating again that neither Roosevelt nor the voters in the 1944 elections thought much about the issue. If anything, the secondary works indicate that FDR respected the Senate's treaty role and sought ways to work with leading Senators on important international agreements, such as the U.N. Charter, rather than avoiding the Senate through new constitutional loopholes. ${ }^{102}$ Leading histories of President Truman's establishment of the Cold War national security state and of the policy of containment, such as John Lewis Gaddis's Strategies of Containment, ${ }^{103}$ Melvyn Leffler's $A$ Preponderance of Power ${ }^{104}$ or Michael Hogan's Cross of Iron,${ }^{105}$ are similarly silent further confirming that no one of any political significance believed that passage of the Bretton Woods or the U.N. agreements signified the acceptance of interchangeability.

It seems unlikely that modern historians have utterly missed a development of such significance, one that would have removed a major stumbling block to American participation in postwar international organizations. The more likely explanation is simply that Ackerman

99. See, e.g., Burns, supra note 90, at 521-31; FrANK FreIdEL, FrankLIN D. RoOSEVELT: A RENDEZVOUS WITH DESTINY 556-76 (1990). The definitive biography of FDR, by Kenneth S. Davis, has yet to reach the 1944 elections. See KenNETH S. DAVIS, FDR: THE BECKONING OF DESTINY, 1882-1928 (1972); FDR: THE NEW YORK YEARS, 1928-1933 (1985); FDR: THE NEW DEAL YEARS, 1933-1937 (1986); FDR: INTO THE STORM, 1937-1940 (1993).

100. Robert Dallek, Franklin D. Roosevelt and AMERICAN Foreign Policy, 1932-1945 (1979); see also ROBERT A. DIVINE, ROOSEVELT AND WORLD WAR II (1969); GADDIS SMITH, AMERICAN DIPLOMACY DURING THE SECOND WORLD WAR, 1941-1945 (1965).

101. See, e.g., Warren F. Kimball, The Juggler: Franklin RoOsevelt as WARTIME STATESMAN (1991); FREDERICK W. MARKS III, WIND OVER SAND: THE DIPLOMACY OF FRANKLIN ROOSEVELT (1988). Specialized historical works on the home front and on wartime economic policy also show no evidence that interchangeability, the congressional-executive agreement, or the Senate's treaty role was an important part of the Roosevelt administration's thinking about the postwar world. See ALAN S. MILWARD, WAR, ECONOMY, AND SOCIETY, 1939-1945 (1977).

102. See, e.g., FREIDEL, supra note 99, at 521-22 (describing Secretary of State Cordell Hull's activities with the Senators of the Committee of Eight to develop a bipartisan policy on international organizations).

103. JohN Lewis Gaddis, Strategies of CONTAINMENT: A CRITICAL APPRAisal OF POSTWAR AMERICAN NATIONAL SECURITY POLICY (1982).

104. MELVYN LEFfLer, A PREPONDERANCE OF POWER: NATIONAL SECURITY, THE TRUMAN ADMINISTRATION, AND THE COLD WAR (1992).

105. Michael J. Hogan, A Cross of IRON: HARRY S. TRUMAN AND THE ORIGINS OF THE NATIONAL SECURITY STATE, $1945-1954$ (1998); see also DaNIEL Yergin, Shattered Peace: The Origins of THE Cold WAR and the National SECurity STATE (1977). 
and Golove have overreached in their use of the constitutional moments theory, have ignored the great wealth of research on Roosevelt, World War II and the origins of the Cold War, and have used primary sources in a manner that is strikingly inconsistent with these broader historical and political accounts.

These problems can be illustrated by another example involving international agreements. In 1951, Senator Bricker promoted a constitutional amendment that would have made clear that treaties were subject to the Constitution's limitations on the powers of the federal government. ${ }^{106}$ In another form, the Bricker Amendment required that congressional-executive agreements could not replace treaties, and yet a different version added that international agreements required congressional legislation to become effective as internal law of the United States. ${ }^{107}$ In other words, the Bricker Amendment would have allowed the national government to make treaties that extended only so far as Congress could legislate under Article I, Section 8, and it also would have required legislation to implement all treaties. This final form of the Bricker Amendment lost by only one vote in the Senate, and only after the Eisenhower administration had publicly declared that it understood the law governing treaties to correspond already to the proposal. ${ }^{108}$ The Bricker Amendment certainly came closer to passage than proposals to strip the Senate of its treaty monopoly ever did. Under the Ackerman thesis, perhaps the Bricker Amendment was the transformative moment, not Bretton Woods, as defeat of the transformative amendment required acquiescence by the President in a new constitutional practice.

One last fault with the transformationist approach to treaties is worth discussion. In order for the Ackerman thesis to work, it needs to see as sharp a break as possible with the politics and law that prevailed immediately before the constitutional moment allegedly occurred. Evolution does not make for an exciting revolution. Ackerman and Golove, therefore, must do all they can to discredit the arguments of the internationalist New Deal scholars who preceded them - they come very close to accusing these intellectuals of misrepresenting precedent and of consciously making up their constitutional theories out of whole cloth. They also must work hard to create as sharp a distinction as possible between the practice of the political branches before the constitutional moment and the practice afterwards. This is a mistake. While there was no long tradition of the use of ex post congressional-executive agreements, the earlier examples of presidential

106. See Duane Tananbaum, The Bricker Amendment Controversy: A Test OF EISENHOWER'S POLITICAL LEADERSHIP (1988).

107. See S.J. Res. 102, 82d Cong. (1951); S.J. Res. 130, 82d Cong. (1952); S.J. Res. 1, 83d Cong. (1953).

108. See TANANBAUM, supra note 106 , at $175-90$. 
and legislative cooperation in foreign affairs showed the possibilities that the constitutional text and structure might have permitted. While the New Deal intellectuals and current-day internationalists may not have settled on the right constitutional basis for the congressionalexecutive agreement, Ackerman and Golove err in reading their arguments as result-oriented justifications for their desired policies. We are left with the conclusion that the transformationist account fails on its own terms.

\section{The Response to the Transformationists: Treaty Exclusivity}

While Ackerman and Golove defend the broad interchangeability of congressional-executive agreements, other leading academics have responded to this new instrument by articulating a theory of treaty exclusivity. Treaty exclusivity holds that the Treaty Clause provides the only constitutional method for reaching significant international agreements. Put simply, exclusivists argue that the Constitution mentions only one method of making international agreements - the treaty - and thus all other means are excluded. While this view has received the approval of various academics over the years, including Edwin Borchard ${ }^{109}$ and Raoul Berger,${ }^{110}$ this Section will focus on Professor Laurence Tribe's recent espousal of treaty exclusivity and his criticisms of the transformationist approach. It will conclude by explaining why treaty exclusivity itself is ultimately an unsuccessful effort to account for the relationship between treaties and statutes.

Replying to Professor Ackerman and Golove's defense of the congressional-executive agreement, Professor Tribe argues that the statutory process for making international agreements violates the Constitution. ${ }^{111}$ Much of Tribe's argument hits home. What Tribe fails to do, however, is provide an explanation for the constitutionality of the congressional-executive agreement, or identify a distinction between treaties and statutes for purposes of making international agreements. Rather, Tribe is left arguing that the Treaty Clause is the exclusive method for making significant international agreements, that the WTO and NAFTA agreements are unconstitutional, and that American presidents and congresses have built much of the postwar world order on unconstitutional foundations.

Tribe effectively criticizes Ackerman's approach to constitutional interpretation on several grounds. He accuses Ackerman and Golove of ignoring the basic architecture of the Constitution, as expressed in (1945).

109. Edwin Borchard, Treaties and Executive Agreements - A Reply, 54 YALE L.J. 616 (1972).

110. Raoul Berger, The Presidential Monopoly of Foreign Relations, 71 MICH. L. REV. 1

111. See Tribe, supra note 14. 
the manner in which its text and structures fit together. Rather than attempting to harmonize the Constitution's different provisions, Ackerman and Golove read them only as "suggestions" or "illustrations" of many possible governmental structures. ${ }^{112}$ Any gap, therefore, in the constitutional text - such as the absence of a provision making clear the Treaty Clause's exclusivity - constitutes an opportunity to provide for an extratextual means of lawmaking. ${ }^{113}$ The Necessary and Proper Clause notwithstanding, the Supreme Court's approach to the separation of powers demonstrates the faults of the Ackerman and Golove approach. In INS v. Chadha, ${ }^{114}$ for example, the Court did not infer any extra congressional power to provide for the legislative veto, while in New York v. United States ${ }^{115}$ the Court did not allow the Necessary and Proper Clause to permit for the commandeering of state legislatures. In both cases, the Constitution's structural guarantees for the protection of the other branches of the federal government and of the states barred use of the Necessary and Proper Clause to transform a constitutional gap into a new form of federal lawmaking. As with the legislative veto and commandeering state governments, Tribe concludes, so it is with the congressional-executive agreement. ${ }^{116}$

Tribe makes several less abstract textual and structural arguments that more directly undermine the transformationist approach. In perhaps his most insightful textual response to Ackerman and Golove, Tribe claims that the transformationist reading conflicts with the Court's understanding of the Appointments Clause. ${ }^{117}$ According to the transformationist account, the Treaty Clause is nonexclusive because it does not expressly prohibit any alternative methods for making international agreements. The Appointments Clause, however, which sits adjacent to the Treaty Clause in Article II, expressly provides for alternative methods: while it requires Senate approval of principal officers of the United States, it allows Congress to vest the appointment of inferior officers in the President, heads of departments, or the federal courts. Thus, in Article II, Section 2 itself, the Framers made exclusive senatorial advice and consent to the appointment of principal officers, and then explicitly created an alternate pro-

112. See Tribe, supra note 14 , at 1245 .

113. See id. at $1239-45$.

114. 462 U.S. 919 (1983).

115. 505 U.S. 144 (1992).

116. Professor Golove has written a lengthy response to Professor Tribe that argues that much of Tribe's criticisms contradict Tribe's own approach to constitutional interpretation. See generally Golove, supra note 38 . Golove argues, for example, that Tribe's arguments would render unconstitutional much of the administrative state - a result that Tribe clearly would not favor. See id. at 1831-32.

117. See Tribe, supra note 14 , at $1272-75$. 
cedure for inferior officers. Application of the canon of expressio unius, Tribe argues, indicates that there is no alternate procedure for the making of international agreements. If the Framers had wanted to provide for other methods for making international agreements, they knew how.

Tribe's second main point is based on the Constitution's provision for a presidential veto over statutes. ${ }^{118}$ According to most authorities, the President has the plenary authority to refuse to ratify a treaty, even after the Senate has consented to it. ${ }^{119}$ Under Article II, it is the President who "makes" the treaty, subject only to Senate advice and consent. But if congressional-executive agreements serve as a valid alternative to treaties, the President has only a conditional veto over statutes that Congress may override by a two-thirds vote. Resort to a statutory method for making international agreements allows Congress to make international agreements over presidential objection, a result forbidden by the text of the Treaty Clause. If Congress can use the Necessary and Proper Clause, Tribe asserts, in combination with its enumerated powers to override presidential opposition, then it also could use the same powers to appoint its own ambassadors and to conduct its own negotiations with foreign powers. Use of the congressional-executive agreement thus has the effect of reducing the President's constitutional prerogatives in foreign relations.

Tribe effectively identifies interpretive, textual, and structural problems with the transformationist defense of interchangeability. He fails, however, to develop a convincing theory to take its place. Tribe's uncompromising reading of the text forces him to conclude that the treaty power is the only method for making significant international agreements, although he concedes that the President can make other nontreaty agreements alone as sole executive agreements. ${ }^{120}$ For Tribe, deciding whether an agreement must receive the consent of a Senate supermajority depends upon whether the "agreement constrains federal or state sovereignty and submits United States citizens or political entities to the authority of bodies wholly or partially separate from the ordinary arms of federal or state government."121 To support this proposition, Tribe relies solely upon a letter written by his colleague, Professor Anne-Marie Slaughter, to a Senator during the Senate's consideration of the WTO. ${ }^{122}$ Absent from Tribe's analysis is any ex-

118. See id. at 1252-57.

119. See RESTATEMENT (THIRD), supra note 7 , at $\$ 303 \mathrm{cmt}$. d; HENKIN, ForeigN AFFAIRS, supra note 6, at 184.

120. See Tribe, supra note 14 , at 1268-69.

121. See id. at 1268.

122. See id. at 1267 n.157. While I have the greatest respect for Professor Slaughter's work, to my knowledge she has never written a scholarly work about the nature of treaties 
amination of the treaty power in light of the Constitution's allocation of powers to other branches of the government, of the historical controversies concerning the treaty power's scope, or of the work of previous scholars who have sought answers to these questions.

More troubling still, the distinction Tribe pursues in defining the Treaty Clause is both too broad and too narrow. Tribe believes that the nation must use treaties whenever it constrains its sovereignty or subjects its citizens to another sovereign power, but he fails to define sovereignty and whether the political branches can delegate it. Tribe fails to understand the difference between international obligations on the one hand, and their implementation according to domestic constitutional processes on the other. This leads him to confuse sovereignty in its international sense and sovereignty in its domestic constitutional sense. Any international obligation, whether assumed by the President alone, by the President and the Senate, or by the Congress as a whole, constrains the sovereignty of the people of the United States. That is the very nature of an international obligation. If Tribe believes that any international agreement that constrains federal or state sovereignty must undergo the treaty process, then all such pacts must be executed as treaties. Tribe himself, however, refuses to go that far, as he acknowledges the constitutionality of sole executive agreements.

Tribe's effort to develop an exclusivist theory fails to understand sovereignty in its domestic sense. The difficult question is not whether an international agreement constrains or delegates national sovereignty, but whether the branches of government will live up to it. While a treaty creates an international obligation, it is the Constitution's allocation of powers to the three branches that provides the powers to fulfill it - no treaty can constrain the lawmaking authority of the federal government. According to the last-in-time rule, for example, Congress is free at any time to override a treaty simply by passing a statute. ${ }^{123}$ Even the President, acting alone, can effectively terminate a treaty. ${ }^{124}$ A treaty cannot permanently alter the sovereignty of the United States or of the American people; it cannot change the allocation of authority between federal and state governments as established by the Constitution. Only a constitutional amendment could achieve that result.

under the American constitutional system, and I am sure that she herself would not hold out her letter as an authoritative examination of the question. While Professor Spiro does not scrutinize the merits of Tribe's distinctions, he likewise expresses surprise that Tribe would rest a critical part of his argument on a letter from a colleague. See Spiro, supra note 15.

123. See, e.g., Chae Chan Ping v. United States, 130 U.S. 581, 600 (1889) (The Chinese Exclusion Case); Whitney v. Robertson, 124 U.S. 190, 194 (1888); Edye v. Robertson, 112 U.S. 580, 599 (1884) (The Head Money Cases).

124. See, e.g., Goldwater v. Carter, 617 F.2d 697, 708-09 (D.C. Cir.), vacated as moot, 444 U.S. 996 (1979); RESTATEMENT (THIRD), supra note 7, at $\$ 339$; HENKIN, FOREIGN AFFAIRS, supra note 6, at 214. 
A constitutional amendment, not a treaty, would also be required to achieve the second class of actions envisioned by Tribe: subjecting American citizens directly to international rules and organizations. The Constitution makes no explicit provision that would allow for the transfer of federal power to entities - outside of the American governmental system - that are not directly responsible to the American people. In a different context, I have outlined the constitutional difficulties with delegating public power outside of the national government. ${ }^{125}$ Placing American citizens under the direct regulation of international law and organizations seems inconsistent with the very Appointments Clause that provides Tribe with such ammunition against Ackerman and Golove. While much recent scholarship on the Clause has focused on the relative roles of the President and Senate in appointing judges ${ }^{126}$ the Court has articulated the Clause's broader function in ensuring that only federal officers accountable to the people's elected representatives may exercise federal power. ${ }^{127}$ As first stated by the Court in Buckley v. Valeo, the Appointments Clause requires that those exercising substantial authority under federal law must undergo appointment according to the Clause's terms. ${ }^{128}$ As subsequent cases explain, this rule prevents Congress from transferring executive law enforcement authority to individuals not responsible to the President or his subordinates. ${ }^{129}$

Read in this manner, the Appointments Clause plays more than a separation of powers role in maintaining the balance between the Congress, the treatymakers, and the President. As Chief Justice Rehnquist has written for the Court, "The Clause is a bulwark against one branch aggrandizing its power at the expense of another branch, but it is more: it 'preserves another aspect of the Constitution's structural integrity by preventing the diffusion of the appointment power." "130 According to the Chief Justice, the Clause prevents the

125. See John C. Yoo, Kosovo, War Powers, and the Multilateral Future, 148 U. PA. L. REV. 1673, 1708-20 (2000) [hereinafter Yoo, Kosovo]; John C. Yoo, The New Sovereignty and the Old Constitution: The Chemical Weapons Convention and the Appointments Clause, 15 Const. COMMENT. 87, 116 (1998) [hereinafter Yoo, New Sovereignty].

126. See, e.g., John O. McGinnis, The President, the Senate, the Constitution, and the Confirmation Process: A Reply to Professors Strauss and Sunstein, 71 TEX. L. REV. 633, 63839 (1993); David A. Strauss \& Cass R. Sunstein, The Senate, the Constitution, and the Confirmation Process, 101 Yale L.J. 1491, 1502-12 (1992); John C. Yoo, Criticizing Judges, 1 GREEN BAG 2D 277, 278 (1998).

127. See, e.g., Edmond v. United States, 520 U.S. 651, 663 (1997); Ryder v. United States, 515 U.S. 177, 180-84 (1995); Weiss v. United States, 510 U.S. 163, 169-76 (1994); Freytag v. Commissioner, 501 U.S. 868, 884 (1991); Buckley v. Valeo, 424 U.S. 1, 135 (1976) (per curiam).

128. Buckley, 424 U.S. at 132.

129. See Edmond, 520 U.S. at 659; see also Printz v. United States, 521 U.S. 898, 922-23 (1997).

130. Ryder, 515 U.S. at 182 (quoting Freytag, 501 U.S. at 878). 
diffusion of federal power by limiting its exercise only to those who undergo the appointment process. ${ }^{131}$ The Framers, the Court concluded, centralized the appointment power because they feared the vesting of power in officeholders who were not accountable to the electorate, as had occurred during the colonial period. A centralized appointment process prevents the national government, as a whole, from concealing or confusing the lines of governmental authority and responsibility so that the people may hold the actions of the government accountable.

Other constitutional structures limit the treatymakers' ability to transfer lawmaking and law enforcement power outside the United States. Whether one agrees with the formalist or functionalist side in the debate over the separation of powers, ${ }^{132}$ transferring power outside of the federal government fundamentally conflicts with the concept of unified executive power. For formalists, any exercise of federal authority by an individual who is not a member of the executive branch, and thus is not removable by the President, unconstitutionally prevents the President from directing the implementation of federal law. ${ }^{133}$ While functionalists may be willing to accept some conditions on the removal power, they have not endorsed the delegation of federal power to those who are completely insulated from the Chief Executive. ${ }^{134}$ Functionalists further would object to such delegation because it would undermine accountability in government. Voters cannot hold either the President or Congress accountable if government actions result from the decisions of officials who do not belong to either branch. The nondelegation doctrine, which has begun to receive renewed attention, ${ }^{135}$ lends added support to this notion. As formulated by the Court, this doctrine prohibits Congress from delegating its enumerated power to another branch unless it has stated an objective, prescribed methods to achieve it, and articulated intelligible

131. See id. at $182-84$ (noting that the Clause prevents diffusion of the appointment power)

132. Compare, e.g., Calabresi \& Prakash, supra note 44 (formalist), with Martin S. Flaherty, The Most Dangerous Branch, 105 YALE L.J. 1725 (1996) (functionalist), and Lawrence Lessig \& Cass R. Sunstein, The President and the Administration, 94 COLUM. L. REV. 1 (1994) (functionalist).

133. See Calabresi \& Prakash, supra note 44 , at 593-99.

134. See, e.g., Morrison v. Olson, 487 U.S. 654, 691-92 (1988) (noting that "good cause" removal of the independent counsel still allows the President to retain authority over the counsel's duties); see also Lessig \& Sunstein, supra note 132, at 106-16 (claiming that although there are numerous independent agencies, complete independence from the President would still raise constitutional problems).

135. See, e.g., Clinton v. New York, 524 U.S. 417, $442-47$ (1998) (striking down the President's use of the Line Item Veto Act where its effect was to amend acts of Congress, thus violating the Presentment Clause); American Trucking Ass'n v. EPA, 175 F.3d 1027, 1033 (D.C. Cir. 1999) (per curiam), rev'd, Whitman v. American Trucking Ass'n, 121 S. Ct. 903 (2001). 
standards to guide administrative discretion. ${ }^{136}$ These standards provide the courts, Congress, and the public with some objective factors to review whether the power is being exercised within the limits of the delegation. Delegating lawmaking or law enforcement authority to foreign or international officials threatens the purposes of this rule. If the political branches transfer such authority over American citizens entirely outside of the federal government, neither Congress nor the public can determine whether foreign or international officials exercise their authority according to American standards, nor can they enforce their policy wishes through the usual legal or political methods available when power is delegated within the executive branch. ${ }^{137}$

Transferring sovereign lawmaking and law enforcement authority to international organizations - by which I mean imposing rules directly upon American citizens within the United States without any intervening participation by domestic governmental organs - threatens these structures. International officials do not undergo the executive, congressional, and public scrutiny that accompanies federal appointments. They are not responsible to the American political system: they are not bound by federal statutory or administrative guidelines, they cannot be removed or disciplined by the President, they need not obey presidential orders, their funding cannot be cut off by Congress, they have no obligation to obey congressional summons to testify, they cannot be sued in American courts for their official actions, and they need not respond to press inquiries. If Congress or the people disagree with the policies established by an international organization, they have no resort to the usual political channels that allow the national political system to control elected officials and the administrative state. Every other exercise of governmental sovereignty - the power to make and enforce laws that directly regulate the conduct of individual citizens - is strictly regulated by the Constitution and subject to the delicate and difficult procedures of the Article I, Section 8 statutory process. It would seem that to allow the federal government to restructure the public lawmaking process to include a significant actor that is independent of the political process would require, at the very least, a constitutional amendment. Neither a treaty nor a congressional-executive agreement will suffice.

An examination of the congressional-executive agreement marking American entry into the new WTO demonstrates the dual faults of

136. See Mistretta v. United States, 488 U.S. 361, 371-79 (1989) (approving a congressional delegation of power where the goals were clearly set out, the purposes asserted, and the scope of the delegation was definitively confined).

137. Elsewhere, I have argued that the original understanding of the Constitution supports this reading of the Constitution and its structures in favor of governmental accountability. See Yoo, Kosovo, supra note 125, at 1717; Yoo, New Sovereignty, supra note 125, at 109. 
Tribe's approach to sovereignty. Tribe believes that the Uruguay Round agreements, which established the WTO, constrains American national or state sovereignty sufficiently to require the use of a treaty. ${ }^{138}$ In one sense, Tribe correctly observes that the WTO limits American sovereignty by committing the United States to a system of rules that constrain its ability to engage in trade-related measures, such as raising tariffs, enacting discriminatory import restrictions, or barring foreign corporations from certain markets. Every international agreement, however, imposes some type of obligation upon the United States - some limit on American sovereignty - for which it receives some benefit. Unless Tribe believes that every single international agreement requires a treaty, his definition of sovereignty at this level is far too broad. This is an extreme position that even Tribe does not espouse, ${ }^{139}$ and one that is at odds with two centuries of national practice.

Along the domestic dimension of sovereignty, Tribe's account of the WTO similarly misses the mark. Even though the WTO may place international obligations upon the United States' trade practices, it places no binding restrictions on American sovereignty or power in the constitutional sense. ${ }^{140}$ Upon agreeing to the new WTO system, the United States agreed to live up to certain substantive trade provisions, but the agreement itself does not directly act upon American citizens. It remains within the purview of the federal government whether to, and how to, live up to the WTO's requirements, consistent with domestic constitutional procedures. For example, the WTO creates a dispute settlement procedure, in which other nations may bring actions to protest American violations of the WTO's terms. A decision by a WTO dispute settlement panel, however, has no binding legal effect within the United States, nor does it have any constitutional impact on the branches of the national government. A WTO body could not order the State of California, for example, to cease discriminatory import restrictions on computer equipment imports from abroad, nor could it legally force the United States to treat South American agricultural imports on an equal footing with American produce. The United States can choose to ignore the WTO decision and keep its laws and policies intact; there is no supranational body that can compel the United States to obey. While aggrieved nations might receive permission from the WTO to impose compensatory sanctions on

138. See Tribe, supra note 14 , at 1267 n.156.

139. See, e.g., id. at 1268-69 (arguing that the President possesses an "unenumerated power to enter non-treaty agreements").

140. See, e.g., Whether Uruguay Round Agreements Required Ratification as a Treaty, Memorandum from Assistant Attorney General Walter Dellinger, to Ambassador Michael Kantor, United States Trade Representative, at 18-21 (Nov. 22, 1994), at http://www.usdoj. gov/olc/gatt.htm. 
American imports, there is no direct regulation of American citizens or parties by any international organization. Tribe's definition of the scope of treaties, therefore, provides little help on this score because neither GATT, NAFTA, nor any international agreement can restrict American sovereignty - the Constitution itself gives to the political branches the discretion whether to comply or to ignore any international obligation. If an international agreement did call for a transfer of sovereignty beyond the limits of the federal government, a constitutional amendment would be required to make the agreement enforceable.

Professor Tribe's conclusion that all congressional-executive agreements violate the Constitution sweeps too far. If Tribe were correct, about ninety percent of all of the international agreements made by the United States since World War II would be invalid. ${ }^{141}$ These agreements include not just postal exchange agreements, but many of the foundations of the postwar economic order, such as Bretton Woods and GATT, and America's recent efforts to expand free trade after the end of the Cold War, such as NAFTA and the WTO. Further, the exclusivist view ignores competing constitutional structures and texts that cut against it. Tribe argues, for example, that the Necessary and Proper Clause cannot justify the congressional-executive agreement, but he provides no explanation for the reach of Congress's plenary power over international commerce. Even if Congress cannot send its own ambassadors or ratify its own international agreements, Tribe's interpretation of the Treaty Clause does not bar Congress from passing statutes involving international commerce that unilaterally accept international obligations.

While Tribe's view reduces the problems created by interchangeability by granting the Treaty Clause a broad scope, it creates its own structural distortions. In order to expand the reach of treaties, the exclusivist view must engage in a corresponding reduction in Congress's constitutional powers. If Tribe concludes that treaties are the exclusive method for entering into international agreements, and if he believes that treaties can be self-executing in the domestic legal system, then his approach leads to the conclusion that the treatymakers can legislate on almost any subject, so long as it is addressed by an international agreement. This would allow the treatymakers to exercise Congress's Article I, Section 8 powers to regulate domestic and international commerce by treaty. To take but one example, if the nation wanted to change the length of time for patents, it generally

141. Professor Golove also has taken Professor Tribe to task for this reason. See Golove, supra note 38, at 1804-05. While Tribe attempts to escape from the results of his arguments by pointing out that some congressional-executive agreements were approved by two-thirds of the Senate anyway, Tribe, supra note 14, at 1227, or that the President could have unilaterally made many such agreements without congressional consent, id. at 1269 , these tentative justifications do not seem convincing. 
would use a statute due to Congress's Article I, Section 8 authority to regulate intellectual property. If an international agreement is involved, however, authority over this subject suddenly would transfer to the treatymakers. Tribe's exclusivist approach would deprive the House of its constitutional function over certain classes of domestic legislation merely because an international agreement became involved.

Tribe might escape this dilemma if he were to accept the view that most treaties are non-self-executing; in other words, that they do not exert a domestic legal effect unless Congress implements their terms by statute. As I will explain in further detail later in this Article, treaty non-self-execution permits a harmonization of the treaty power and the legislative power by precluding treaties from exercising any power granted to the legislature in Article I, Section 8. Tribe might argue, as I have, that treaties could form the primary method for international agreement-making because all domestic implementation would remain in the hands of Congress, thereby avoiding structural contradictions created by the potential overlap of the treaty and legislative powers. Tribe, however, does not appear to take this view in his criticism of the transformationist school. ${ }^{142}$ Indeed, he appears to take the opposite position, because his criticism is that the WTO - enacted as a statute - enjoys the powers of a treaty without its form. If Tribe accepted that treaties were non-self-executing, then the WTO's passage as a statute would be of little concern, because the government would still need to pass a statute to implement its terms. Even if Tribe were to adopt a general non-self-execution view, his approach to international agreements does not explain why some treaties may immediately take effect domestically, while others must await congressional implementation.

Finally, Tribe's exclusivist reading fails to take account of the changing nature of international law and organizations. As is becoming clear, many areas of life that were once considered wholly domestic have become international in scope. ${ }^{143}$ International agreements now regulate issues such as crime, national security, the environment, economic regulation, and individual rights - issues that used to be governed primarily by domestic legislation. These agreements seek to mimic domestic legislation in directly regulating the conduct of private individuals and in creating their own independent means of lawmaking and law enforcement. If the exclusivist reading were correct, then we should expect the Treaty Clause to have expanded in recent years, rather than retracted, as international agreements have come to play a more important role in domestic regulation. Tribe's approach would

142. Tribe, supra note 14 , at $1261 \mathrm{n} .133$; see also LAURENCE H. TRIBE, 1 AMERICAN CONSTITUTIONAL LAW 644 (3d ed. 2000).

143. See, e.g., Yoo, Globalism, supra note 8, at 1967-69. 
shift the locus for domestic regulation from the normal legislative process to the supermajority Treaty Clause process, which excludes the House. These and other issues will be the subject of Parts II and III, which will explain why both full interchangeability and the exclusivist reading of the Treaty Clause are flawed and incomplete, and then present a new theory of treaties and congressional-executive agreements.

\section{Practice, Public Lawmaking, AND the Congressional- EXECUTIVE AGREEMENT}

A starting point for a durable theory of international agreements must recognize that the practice of the political branches roughly delineates separate spheres for treaties and statutes. Not only ought theory explain this record, but it also should provide a satisfying account of how international agreement-making interacts with our general public lawmaking system. Theories that create anomalies and contradictions in the manner in which the branches participate in making laws ought to be rejected in favor of a theory that accounts for practice in a manner consistent with the text, structure, and original understanding of the Constitution.

Judged by these standards, the internationalist, transformationist, and exclusivist approaches fail. As an initial matter, the sweeping conclusions of all three camps cannot account for the practice of the political branches during the postwar period. If the internationalists or transformationists were right, one would expect to see the nation use congressional-executive agreements in almost every instance. If the exclusivist theory were correct, the branches should have used treaties to make all international agreements. Yet, as will become clear, the political branches continue to use both instruments of foreign policy. Further, they do so in a way that maintains a subject matter distinction between the two, something that none of the academic theories on international agreements can explain. In my view, this record of practice not only represents a practical way to work out the conflict between treaties and statutes, but also shows how deeper structural imperatives in the Constitution have led the branches to interact in a way that harmonizes their potentially conflicting powers. As such, practice can provide a true reflection of a correct reading of the Constitution.

An even more significant defect in these theories is their creation of severe conflicts within the constitutional text and structure. Advocates of full interchangeability ignore the fundamental problems that emerge when statutes take the place of treaties. Under the current consensus view, for example, treaties enjoy a substantial amount of freedom from the normal constitutional limitations that apply to statutes. Allowing statutes to replace treaties would permit Congress to expand its Article I powers beyond their current boundaries. Nor do those who believe that the treaty power is exclusive avoid structural 
difficulties. As domestic affairs become more international, and hence increasingly subject to international regulation, international agreements will assume a greater role in imposing rules of conduct on private citizens. Treaties could potentially replace statutes as a method for domestic legislation. Because of the expansive sweep of the Treaty Power, regulation through international agreement could reach well beyond the limits on Congress's statutory powers.

This Part will begin to construct a theory that addresses these practical, textual and structural problems. First, it will discuss the practice of making international agreements in the postwar period, with the goal of identifying the line between statutes and treaties. Second, it will argue that statutes and treaties must remain distinct due to the constitutional contradictions that arise when one replaces the other. Part III will then propose a different way to conceptualize congressional-executive agreements, and the manner in which they can be distinguished from the treaty process, to solve these problems.

\section{A. The Record of Practice}

Practice is of particular importance in foreign affairs law. Due to the lack of authoritative judicial precedent, many of the issues involving the Constitution and international relations do not have clear answers. In such circumstances, the executive and legislative branches often have taken the lead in interpreting the Constitution, and this practice can provide us with guidance as to a realistic, workable construction of its terms. As Justice Frankfurter observed in Youngstown Sheet \& Tube, "The Constitution is a framework for government. Therefore the way the framework has consistently operated fairly establishes that it has operated according to its true nature."144 In domestic areas, judicial precedent represents the experience of courts in working out the Constitution's text and structure within different practical contexts; in the absence of case law, practice by the political branches provides a similar record in foreign affairs. Recognizing this, the Supreme Court often has deferred on foreign affairs questions to the practical construction of a constitutional provision by the political branches. ${ }^{145}$ Prominent foreign affairs scholars, such as Professors Harold Koh and Gerhard Casper, often have followed suit. ${ }^{146}$

144. Youngstown Sheet \& Tube Co. v. Sawyer, 343 U.S. 579, 610 (1952) (Frankfurter, J., concurring).

145. See, e.g., United States v. Verdugo-Urquidez, 494 U.S. 259, 273 (1990); Dames \& Moore v. Regan, 453 U.S. 654, 686 (1981).

146. $\mathrm{KOH}$, supra note 6 , at 70-71 (discussing quasi-constitutional custom as a source of law in foreign affairs); Gerhard Casper, Constitutional Constraints on the Conduct of Foreign and Defense Policy: A Nonjudicial Model, 43 U. CHI. L. REV. 463, 478 (1976). 
No scholar has yet conducted an empirical survey upon which to test his or her theory of treaties and congressional-executive agreements. This Article will be the first to show that customary practice indicates that the political branches have observed discernable lines in the use of these instruments of national policy. ${ }^{147}$ Viewed in this light, the practice of the political branches in making international agreements strikes at the heart of both the internationalist and the transformationist approaches. Traditional explanations for the congressional-executive agreement maintain that congressional-executive agreements have always served as a perfect substitute for the treaty. A demonstration that ex post congressional-executive agreements are of relatively recent vintage, and that even today they have not achieved full interchangeability with treaties, undermines internationalist claims. Without the pedigree provided by the consistent practice of the political branches and by the imprimatur of the courts, internationalists are left only with the textual arguments that they have developed to justify the substitution of statutes for treaties. As argued above, these arguments leave the congressional-executive agreement with very weak foundations indeed.

Practice also deals a fatal blow to the transformationists. Their case depends not only on the notion that the defenders of the ancient regime capitulated to the changes wrought by the constitutional moment, but also that the old guard, as it were, itself observes the new constitutional settlement. ${ }^{148}$ It is not much of a constitutional moment if no one remembers it. A history of consistent practice that distinguishes between treaties and congressional-executive agreements con-

147. In his forthcoming article, Professor Spiro takes note of the consistent use of treaties in some areas, such as arms control and human rights. Spiro, supra note 15. Spiro, however, does not seek to identify systematically what areas have consistently been subject to treaties or congressional-executive agreements, nor is it his object to develop a theory that explains the line between the two instruments. $I d$. Rather, Spiro seeks to establish a new theory of interpretation that depends upon historical developments and political practice to legitimate constitutional change. While this Article is not the place to conduct a thorough examination of Spiro's theory, it seems to me that his approach - while critical of Ackerman's theory of constitutional moments - is equally flawed by allowing politics to trump the text and structure of the Constitution. In regard to interchangeability, for example, Spiro can supply no coherent line between treaties and congressional-executive agreements aside from the fact that the political branches simply have acted differently in different areas, without reference to the constitutional text and structure. Spiro's approach is a constitutional theory of political fiat - if the political branches follow a certain practice, it becomes constitutional. The problems with this theory are clear - Spiro would be forced to accept, for example, the constitutionality of Plessy v. Ferguson and the entrenchment of Jim Crow between 1877 and 1954. He provides no normative guide to judge the constitutionality of government action, beyond whether the people of that time approve of its constitutionality. Cf. John C. Yoo, Choosing Justices: A Political Appointments Process and the Wages of Judicial Supremacy, 98 MICH. L. REV. 1436, 1449 (2000) (book review) (criticizing a related theory that constitutional outcomes are legitimate based on the political support they receive).

148. See ACKerman, We the PeOPle: Foundations, supra note 13, at $48-49$ (discussing "the period of ratification"). 
tradicts the Ackerman and Golove theory, because no definitive "codification" of the constitutional moment into formal legal doctrine ever took place - a critical stage of the general transformationist theory of constitutional change. ${ }^{149}$ Even after the alleged constitutional moment, the political branches appear to have observed subject matter distinctions between treaties and congressional-executive agreements. This leads to two possible conclusions: either none of the branches understood the decision to approve the Bretton Woods agreement by statute as a significant metamorphosis in constitutional doctrine, or the 1944 transformation was a stillborn constitutional moment because it failed to stick over time.

Let us first examine how practice undermines the standard account of congressional-executive agreements. The doctrine of interchangeability has not been with us always, nor has it ever held full sway. As Professors Ackerman and Golove have argued in their exhaustive examination of international agreement-making during the interwar era, the nation does not appear to have used, before 1945, the ex post congressional-executive instrument to substitute for the treaty process. ${ }^{150}$ To be sure, some precedents came close. As mentioned earlier, Congress had provided ex ante authorizations to the President to engage in reciprocal tariff reduction or other trade measures. These measures, however, involved congressional delegation of factfinding powers to the President, in which certain trade restrictions were reduced once the President had found that another nation had ended its discrimination against American goods. These laws can be characterized as international agreements only because the President could negotiate, if he wished, with foreign countries to secure for them the benefits of the statute; the statute's provisions themselves do not require an international agreement in order to take effect.

To the extent that traditional defenders of the congressionalexecutive agreement can rely upon practice, it is only the practice of the postwar world. ${ }^{151}$ Since 1945 , Presidents and Congress have used

149. See id. at 288-90 (discussing the codification stage of transformation).

150. Ackerman \& Golove, supra note 13, at 813-61.

151. Traditional accounts of the congressional-executive agreement sometimes rely upon the annexations of Texas and Hawaii to show historical support for interchangeability. In both cases, Congress decided to annex these territories by statute after treaties to do the same had been withdrawn due to Senate opposition. While the annexations of Texas and Hawaii appear similar to the subjects that ordinarily would fall within the treaty power, the unique facts of those cases seem to permit use of the statutory process. Both Texas and Hawaii were independent nations at the time of the annexations. Their absorption into the United States did not involve an agreement with another sovereign nation, as occurred, for example, with the Louisiana Purchase or with the transfer of territory at the end of the Mexican-American or Spanish-American wars. See id. at 832-36. One could view the annexations as the voluntary request of another nation to join the United States. A treaty would be unnecessary because the other party would no longer exist once the agreement was executed. A statutory process may have been further appropriate due to Congress's plenary authority to govern territories and admit new states. 
the statutory method to enter the nation into sweeping agreements, such as NAFTA and the WTO, which have established America's place in the world trading system. Presidents and Congress have resorted to congressional-executive agreements, rather than treaties, to join international organizations, such as the IMF and the World Bank. Certain statutes, such as the Atomic Energy Act of $1946^{152}$ and the Arms Control and Disarmament Act of $1961,{ }^{153}$ explicitly allow the President to submit international agreements in specified areas to statutory approval rather than as treaties. Congressional-executive agreements, which now appear to outnumber treaties by about fourteen to one, have included such diverse subject matter areas as intellectual property rights, foreign assistance, and fishery rights. ${ }^{154}$ Even the Senate Foreign Relations Committee, which one would expect to maintain the Senate's prerogatives in the making of international agreements, has issued a report that admits that "it is now well-settled that the treaty mode is not an exclusive means of agreement-making for the United States and that [congressional-]executive agreements may validly co-exist with treaties under the Constitution." $" 155$

Despite this statement against interest, however, complete interchangeability has not been borne out in practice. A review of American postwar international agreements indicates that the political branches have reserved certain areas, specifically national security and arms control, for the treaty process. The political branches' consistent maintenance of subject matter distinctions between treaties and congressional-executive agreements not only directly contradicts the interchangeability thesis (whether of the internationalist or transformationist variety), but also shows that deeper separation of powers

Professor Spiro, however, raises doubts about the transformationist account of preWorld War II practice on international agreements. He argues that some early precedents, such as agreements joining the International Labor Organization and addressing World War I British war debts lend more support for the use of statutes to make international agreements. As Spiro claims, these "earlier examples of other forms of non-treaty agreements, combined with some instances in which international agreements were subjected to ex post bicameral approval, in fact laid a tenable basis for a more extended use of the congressionalexecutive agreement." Spiro, supra note 15. If true, Spiro's point further undermines the Ackerman and Golove defense of a constitutional moment in the 1944-45 period.

152. Atomic Energy Act of 1946, Pub. L. No. 79-585, § 8(a)-(b), 60 Stat. 755, 765 (codified as amended at 42 U.S.C. $\$ 2011$ (1994)) (providing that any treaty approved by the Senate or other international agreement approved by Congress supercedes inconsistent provisions of statute).

153. Arms Control and Disarmament Act of 1961, Pub. L. No. 87-297, § 33, 75 Stat. 631, 634 (codified as amended at 22 U.S.C. $\$ \$ 2551-2595$ (1994)). For the particular provision permitting the President to commit the nation to arms control agreements only pursuant to a treaty or legislation passed by Congress, see 22 U.S.C. $\$ 2753(\mathrm{c})$.

154. See SENATE 1993 REPORT, supra note 5, at 53.

155. Id. at 52 . 
principles are afoot. This Section will now survey the subjects for which the political branches have reserved the treaty process. ${ }^{156}$

Political Agreements. In the early postwar period, significant agreements such as the peace treaties with Japan and Italy, the entry of the United States into the United Nations ("U.N.") and the North Atlantic Treaty Organization ("NATO"), and the current web of U.S. mutual defense agreements, such as bilateral agreements with South Korea, ${ }^{157}$ the Philippines, ${ }^{158}$ Japan, ${ }^{159}$ and Taiwan (terminated in 1978), ${ }^{160}$ and multilateral security arrangements, such as the Southeast Asian Treaty Organization, the Australian-New Zealand-U.S. agreement, and the Rio Treaty, occurred by treaty. ${ }^{161}$ With one exception, subsequent, less-intensive security agreements, such as promises to defend against threats, training of local forces, or pre-positioning of equipment, have resulted from unilateral executive declarations or sole executive agreements, and none of those rose to the level of seriousness of America's entry into the U.N. or NATO. ${ }^{162}$ Perhaps the most significant international security arrangements to arise from the end of the Cold War also were formalized by treaty - the final settlement with regard to Germany ${ }^{163}$ and expansion of NATO to include some of the nations of the formerly communist Eastern Europe. ${ }^{164}$ While some exceptions exist, they do not seem to undermine the general subject matter trend. ${ }^{165}$

156. I conducted this survey by relying upon the U.S. DEP'T OF STATE, TREATIES IN FORCE: A LIST OF TREATIES AND OTHER INTERNATIONAL AGREEMENTS OF THE UNITED STATES IN FORCE ON JANUARY 1, 2000 (2000), which groups agreements by subject-matter and by party. I then used the Statutes at Large and the United States Treaty Series to verify whether an agreement had undergone the treaty process or the statutory process.

157. Mutual Defense Treaty, Oct. 1, 1953, U.S.-S. Korea, 5 U.S.T. 2368.

158. Mutual Defense Treaty, Aug. 30, 1951, U.S.-Phil., 3 U.S.T. 3947.

159. Treaty of Mutual Cooperation and Security, Jan. 19, 1960, U.S.-Japan, 11 U.S.T. 1632.

160. Mutual Defense Treaty, U.S.-Taiwan (China), Dec. 2, 1954, 6 U.S.T. 433.

161. Southeast Asia Collective Defense Treaty, Sept. 8, 1954, 6 U.S.T. 81, 209 U.N.T.S. 28; Security Treaty (ANZUS Pact), Sept. 1, 1951, 3 U.S.T. 3420, 131 U.N.T.S. 83; InterAmerican Treaty of Reciprocal Assistance (Rio Treaty), Sept. 2, 1947, T.I.A.S. No. 1838, 21 U.N.T.S. 77. See also Spiro, supra note 15.

162. See SENATE 1993 REPORT, supra note 5, at 206-07.

163. Treaty on the Final Settlement with Respect to Germany and a Related Agreed Minute, Sept. 12, 1990, S. TREATY DOC. No. 101-20 (1990), 29 I.L.M. 1186.

164. See Protocols to the North Atlantic Treaty of 1949 on the Accession of Poland, Hungary, and the Czech Republic, Dec. 16, 1997, S. TREATY DOC. NO. 105-36 (1998).

165. The three significant exceptions appear to be the 1973 Paris agreement ending the Vietnam War, the 1988 agreement settling the Afghanistan conflict, and the 1991 agreement ending the Cambodian conflict. The latter two agreements did not involve use of American troops in combat. While the first did, it was not submitted for approval to Congress, but instead constituted a sole executive agreement that President Nixon appears to have undertaken pursuant to his sole executive powers. See Act of the International Conference on Viet-Nam, Mar. 2, 1973, 24 U.S.T. 485, 935 U.N.T.S. 405. 
Standing alone, even the ratification of the United Nations Charter by the normal treaty process strikes a deadly blow to the transformationist and internationalist defense of interchangeability. If the Ackerman/Golove account is to be believed, the political controversy that surrounded the alleged 1944-45 constitutional moment focused on America's entrance into a permanent international body to guarantee the peace. Concern over whether the Senate would oppose entry into the United Nations prompted an earlier generation of internationalist scholars in 1944-45 to create the theory of interchangeability. These scholars blamed America's failure to join the U.N.'s predecessor, the League of Nations, for the coming of the Second World War. If the transformationists were correct, the constitutional moment should have allowed Truman to seek entry into the U.N. by congressionalexecutive agreement. If today's internationalists were right, the Constitution's textual permission for interchangeability likewise should have led Truman to seek a congressional-executive agreement for the U.N., if only to avoid the potential political obstacles looming in the Senate. Despite all of these concerns, the United States entered the United Nations through the treaty form. It does not appear that there was any serious effort to enact this most significant of all postwar treaties by the statutory method.

Arms Control. Recent experience with arms control cuts even more sharply against interchangeability. Since the end of World War II, Presidents submitted almost every significant arms control agreement, such as the Limited Nuclear Test Ban Treaty, ${ }^{166}$ the Threshold Test Ban Treaty, ${ }^{167}$ the Anti-Ballistic Missile Treaty, ${ }^{168}$ the Nuclear Non-Proliferation Treaty, ${ }^{169}$ the Intermediate-Range Nuclear Forces Treaty, ${ }^{170}$ and the Treaty on Conventional Armed Forces in Europe, ${ }^{171}$ to the Senate as treaties. ${ }^{172}$ These agreements established the policy of

166. Treaty on Underground Nuclear Explosions for Peaceful Purposes, May 28, 1976, U.S.-U.S.S.R., 15 I.L.M. 891; Treaty Banning Nuclear Weapons Tests in the Atmosphere, in Outer Space, and Under Water, Aug. 5, 1963, 14 U.S.T. 131, 480 U.N.T.S. 43.

167. Treaty on the Limitation of Underground Nuclear Weapon Tests, July 3, 1974, U.S.-U.S.S.R., 13 I.L.M. 906.

168. Treaty on the Limitations of Anti-Ballistic Missile Systems, May 26, 1972, U.S.U.S.S.R., 23 U.S.T. 3435.

169. Treaty on the Non-Proliferation of Nuclear Weapons, done July 1, 1968, 21 U.S.T. 483, 729 U.N.T.S. 161.

170. Treaty between the United States of America and the U.S.S.R. on the Elimination of Their Intermediate-Range and Shorter-Range Missiles, Dec. 8, 1987, U.S.-U.S.S.R., 27 I.L.M. 90.

171. Treaty on Conventional Armed Forces in Europe, done Nov. 19, 1990, S. TREATY DoC. No. $102-8$ (1991), 30 I.L.M. 1.

172. See SENATE 1993 REPORT, supra note 5, at 209-10 (observing that most arms control agreements have been submitted to the Senate as treaties); see also Treaty on the Prohibition of the Emplacement of Nuclear Weapons and Other Weapons of Mass Destruction on 
nuclear deterrence through mutually assured destruction, sought to restrict the spread of nuclear weapons, and began the de-militarization of Europe. There appears to have been only one exception to this consistent pattern: approval by statute of the first round of the Strategic Arms Limitations Talks ("SALT I") between the United States and the Soviet Union, which imposed limits upon the nuclear warheads and delivery vehicles possessed by the superpowers. ${ }^{173}$ Approval of SALT I by statute, however, cannot serve as a firm precedent for interchangeability. SALT I had a limited duration of only five years; both sides understood that SALT I would be replaced by a permanent pact, SALT II. ${ }^{174}$ Indeed, the agreement was formally known as the SALT I Interim Agreement. And when negotiation of SALT II was finally completed, President Carter initially sent the agreement to the Senate for approval as a treaty, but then did not press for its approval in the wake of the Soviet invasion of Afghanistan. ${ }^{175}$ Presidents Reagan and Bush never asked the Senate to approve the agreement.

Experience since the Cold War has only reaffirmed the consistent use of the treaty to make arms control agreements. Presidents have submitted to the Senate bilateral agreements between the United States and Russia, such as the Strategic Arms Reduction Talks ("START") I and II agreements, which have reduced the level of nuclear warheads and restricted the use of certain delivery systems. ${ }^{176}$ Presidents have sent to the Senate agreements with our former Cold War adversary that have reduced the positioning of conventional weapons in the European theater of operations, and that have allowed unimpeded over-flights to verify compliance with arms control pacts. ${ }^{177}$ The political branches have also chosen to use the treaty process to approve controversial multilateral arms control agreements, such as the Chemical Weapons Convention, even when they faced significant opposition in the Senate. ${ }^{178}$ Agreements that the United States has not

the Seabed and the Ocean Floor and in the Subsoil Thereof, done Feb. 11, 1971, 23 U.S.T. 701, 955 U.N.T.S. 155. See also Spiro, supra note 15.

173. Strategic Arms Limitation I Agreement, Pub. L. No. 79-448, 86 Stat. 746.

174. See Trimble \& Weiss, supra note 6 , at 657-60.

175. See HENKIN, FOREIGN AFFAIRS, supra note 6, at 179.

176. See Treaty on Further Reduction and Limitation of Strategic Offensive Arms, Jan. 3, 1993, U.S.-USSR, S. TREATY DOC. No. 103-1 (1993) [hereinafter The START II Treaty]; Treaty on the Reduction and Limitation of Strategic Offensive Arms, July 31, 1991, U.S.USSR, S. TREATY DOC. NO. 102-20 (1991) [hereinafter The START I Treaty].

177. See Treaty on Armed Conventional Forces in Europe, supra note 171; Flank Document Agreement to the Conventional Armed Forces in Europe Treaty, adopted May 31, 1996, S. TREATY DOC. No. 105-5 (1997), 36 I.L.M. 866.

178. Convention on the Prohibition of Development, Production, Stockpiling and Use of Chemical Weapons and on Their Destruction, Jan. 13, 1993, S. TREATY DOC. No. 103-21 (1993). 
yet signed, such as the Land Mines Convention, ${ }^{179}$ and agreements still in development, such as the strengthening of the Biological Weapons Convention, ${ }^{180}$ would take the form of treaties, rather than of congressional-executive agreements.

In part, this consistent treaty practice seems to have resulted from Senate efforts to defend its prerogatives. During ratification of the last round of arms control agreements, for example, the Senate included in the resolution of advice and consent a condition that all future agreements involving military, security, or arms control issues must be submitted to the Senate as treaties rather than as congressional-executive agreements. ${ }^{181}$ To be sure, the Senate's ability to create binding constitutional law through the attachment of reservations, understandings and declarations to treaty ratification documents may be open to doubt. ${ }^{182}$ Nonetheless, the Senate's attachment of this condition expresses its own intention not to accept the theory of interchangeability, and indicates that it will enforce this understanding of the Constitution by refusing to approve any international agreements that do not take the treaty form. Indeed, the Clinton administration so understood the condition and agreed to abide by it. ${ }^{183}$

Human Rights. In addition to political/military and arms control agreements, one of the most significant areas of recent American foreign policy is conducted primarily through treaties, rather than congressional-executive agreements: human rights. Historically, significant human rights agreements, such as the Hague conventions on the rules of war and the Red Cross conventions, underwent the supermajority Senate consent process. ${ }^{184}$ In more recent times, the Bush ad-

179. Convention on the Prohibition of the Use, Stockpiling, Production and Transfer of Anti-Personnel Mines and on Their Destruction, adopted Sept. 18, 1997, 36 I.L.M. 1507.

180. Convention on the Prohibition of the Development, Production and Stockpiling of Bacteriological (Biological) and Toxin Weapons and on Their Destruction, opened for sig. nature Apr. 10, 1972, 26 U.S.T. 583, 1015 U.N.T.S. 163.

181. See Trimble \& Koff, supra note 49 , at 56.

182. See Curtis A. Bradley \& Jack L. Goldsmith, Treaties, Human Rights, and Conditional Consent, 149 U. PA. L. REV. 399 (discussing constitutional validity of the Senate's use of reservations, understandings, and declarations in the treaty process).

183. See Trimble \& Koff, supra note 49 , at 56.

184. Convention Relative to the Protection of Civilian Persons in Time of War, done Aug. 12, 1949, 6 U.S.T. 3516, 75 U.N.T.S. 287; Geneva Convention Relative to the Treatment of Prisoners of War, done Aug. 12, 1949, 6 U.S.T. 3316, 75 U.N.T.S. 135; Geneva Convention for the Amelioration of the Condition of Wounded, Sick and Shipwrecked Members of Armed Forces at Sea, done Aug. 12, 1949, 6 U.S.T. 3217, 75 U.N.T.S. 85; Geneva Convention for the Amelioration of the Condition of the Wounded and Sick in Armed Forces in the Field, done Aug. 12, 1949, 6 U.S.T. 3114, 75 U.N.T.S. 31; Convention of July 27, 1929, Relative to the Treatment of Prisoners of War, July 27, 1929, 47 Stat. 2021; Convention Respecting the Rights and Duties of Neutral Powers and Persons in Case of War on Land, Oct. 18 1907, 36 Stat. 2310; Convention Respecting the Laws and Customs of War on Land, Oct. 18, 1907, 36 Stat. 2277; Convention with Respect to the Laws and Customs of War on Land, July 29, 1899, 32 Stat. 1803; see also Spiro, supra note 15. 
ministration used treaties to formalize American entry into the International Covenant on Civil and Political Rights ("ICCPR"), which guarantees certain minimum individual rights in the political sphere, ${ }^{185}$ and the Genocide Convention, which makes genocide a crime against humanity. ${ }^{186}$ President Clinton followed suit. The two important human rights agreements approved during his presidency, the Convention against Torture in $1994,{ }^{187}$ and the International Convention on the Elimination of All Forms of Racial Discrimination in 1994, ${ }^{188}$ took the treaty form. Four other multilateral human rights agreements that supporters once thought that the Clinton administration would seek to join ${ }^{189}$ - the Convention on the Elimination of all Forms of Discrimination against Women, ${ }^{190}$ the Covenant on Economic, Social and Cultural Rights, ${ }^{191}$ the Inter-American Convention on Human Rights, ${ }^{192}$ and the Convention on the Rights of the Child ${ }^{193}$ - also would take treaty form, even in the face of likely Senate opposition. Indeed, it is difficult to think of a human rights agreement that has gone through two-house approval, rather than through the President and Senate alone.

The history of these human rights treaties highlights the fact that the political branches recognize a distinction between treaties and congressional-executive agreements. Some human rights agreements have languished in the Senate for up to 30 years. The ICCPR, for example, had been proposed first in 1966, but was not ratified until 1992. The Genocide Convention was first presented for signature in 1948, but was not ratified by the United States until 1989. Senate leaders opposed several of these treaties because of the concern that they re-

185. International Covenant on Civil and Political Rights, Dec. 19, 1966, 999 U.N.T.S. 171 (providing for equal rights, a right against arbitrary arrest, a right to marriage, and restricted use of the death penalty, and establishing a Human Rights Committee).

186. Convention on the Prevention and Punishment of the Crime of Genocide, Dec. 9, 1948, S. EXEC. DOC. O, 81-1, S. Exec. Doc. B, 91-2, 78 U.N.T.S. 277 (entered into force for U.S., Feb. 23, 1989).

187. Convention Against Torture and Other Cruel, Inhuman, or Degrading Treatment or Punishment, entered into force June 26, 1987 (for U.S., Nov. 20, 1994), S. TREATY DOC. No. 100-20 (1988), 1465 U.N.T.S. 113.

188. International Convention on the Elimination of All Forms of Racial Discrimination, opened for signature Mar. 7, 1966, S. EXEC. DOC. C, 95-2 (1978), 660 U.N.T.S. 195 (entered into force for U.S., Nov. 20, 1994).

189. See, e.g., Louis Henkin, U.S. Ratification of Human Rights Conventions: The Ghost of Senator Bricker, 89 AM. J. INT'L L. 341 (1995).

190. Convention on the Elimination of All Forms of Discrimination against Women, Dec. 18, 1979, 1249 U.N.T.S. 13.

191. International Covenant on Economic, Social and Cultural Rights, adopted Dec. 16, 1966, 993 U.N.T.S. 3.

192. American Convention on Human Rights, Aug. 27, 1979, 1144 U.N.T.S. 123.

193. Convention on the Rights of the Child, adopted Nov. 20, 1989, 28 I.L.M. 1448. 
quire more expansive individual rights than those in the Constitution. ${ }^{194}$ To mention one disreputable example, southern Senators feared that certain human rights treaty provisions would hasten the dismantling of segregation. ${ }^{195}$ If treaties and congressional-executive agreements truly were interchangeable, Presidents could have shortcircuited this opposition by sending human rights agreements to both houses of Congress for majority approval. This course of action would have been all the more successful once much of the political opposition to the goals of the treaties had disappeared in the wake of the Civil Rights revolution. Yet it does not appear that Presidents have ever attempted to use the alternate statutory procedure to avoid such political opposition in the Senate. ${ }^{196}$

Extradition. Yet another area where the political branches generally have resorted to treaties to reach international agreements has been extradition. Under standard extradition agreements, one nation agrees to surrender a person charged with or convicted of a crime under the law of another state, so that the latter state may try or punish the individual. ${ }^{197}$ Although at one time it was thought that nations had a duty to grant extradition freely, customary international law never recognized a general duty to surrender fugitives. ${ }^{198}$ As a result, the United States and other nations have entered into a web of bilateral agreements that generally require a showing that there is cause to hold a person, that the offense has been created by treaty or statute, that the offense was within the jurisdiction of the requesting country, and that double jeopardy would not be violated. ${ }^{199}$ Article 27 of the 1794 Jay Treaty with Great Britain contained the first American extradition provision, ${ }^{200}$ and its implementation by President John Adams produced one of the early Republic's great foreign policy crises. ${ }^{201}$

194. For a review of historical examples, see NATALIE HEVENER KAUFMAN, HUMAN RIgHTS TREATIES AND THE SENATE: A HISTORY OF OPPOSITION (1990).

195. See TANANBAUM, supra note 106 , at 15.

196. This information is all the more striking in light of the fact that several significant treaties have yet to be approved by the Senate decades after they were submitted. The International Labor Organization Convention No. 87, for example, has been awaiting Senate approval since 1949; the International Convention on Economic, Social and Cultural Rights, since 1978; the American Convention on Human Rights, since 1978; and the Convention on the Elimination of All Forms of Discrimination against Women, since 1980.

197. See, e.g., Holmes v. Jennison, 39 U.S. (14 Pet.) 540 (1840); Terlinden v. Ames, 184 U.S. 270 (1902); Valentine v. United States, 299 U.S. 5 (1936).

198. See RESTATEMENT (THIRD), supra note 7, at $\S 474$.

199. See generally id.

200. Treaty of Amity, Commerce and Navigation, Nov. 19, 1794, U.S.-Gr. Brit., 8 Stat. 116 (signed at London, approved by the Senate June 24, 1795, ratified by the United States, Aug. 14, 1795).

201. For a discussion of the constitutional issues arising from this early extradition controversy, see Ruth Wedgwood, The Revolutionary Martyrdom of Jonathan Robbins, 100 YALE L.J. 229 (1990). 
Extradition poses an interesting question in regard to federal power, as Congress does not appear to possess any textual authority to provide for the seizure of an individual on American soil and for his delivery to a foreign nation for trial. Ever since the Jay Treaty, however, the political branches have used Article II treaties to reach extradition agreements with more than one-hundred nations. ${ }^{202}$ Only a single recent example appears to have broken this record. In 1994 and 1995, the President entered into executive agreements with the International Criminal Tribunals for the Former Yugoslavia and Rwanda to surrender persons within the United States charged or convicted by those tribunals. ${ }^{203}$ Rather than approval by treaty, Congress implemented the agreements by statute by expanding federal extradition laws - which until 1996 had implemented treaties - to include the two international tribunals. ${ }^{204}$ In a 1999 challenge brought by a Rwandan citizen in the United States indicted by the Rwanda tribunal, a divided panel of the U.S. Court of Appeals for the Fifth Circuit upheld the use of the congressional-executive agreement. ${ }^{205}$ Citing dicta from previous extradition cases, the majority relied upon interchangeability even though the plaintiff maintained that "the United States has never surrendered a person except pursuant to an Article II treaty." ${ }^{206}$ In dissent, Judge DeMoss demonstrated that the majority's new exception proves the rule. "Every extradition agreement ever entered into by the United States (before the advent of the new Tribunals) has been accomplished by treaty . ..."207 Aside from this sole, rushed example, extradition has stood as another example in which the treaty power has provided the sole mechanism for reaching international agreements.

202. See SENATE 1993 REPORT, supra note 5, at 227.

203. Agreement Between the United States of America and the International Tribunal for the Prosecution of Persons Responsible for Genocide and Other Serious Violations of International Humanitarian Law Committed in the Territory of Rwanda and Rwandan Citizens Responsible for Genocide and Other Such Violations Committed in the Territory of Neighbouring States, Jan. 24, 1995, T.I.A.S. No. 12601; Agreement Between the United States of America and the International Tribunal for the Prosecution of Persons Responsible for Genocide and Other Serious Violations of International Humanitarian Law in the Territory of the Former Yugoslavia, Oct. 5, 1994, T.I.A.S. No. 12570.

204. See National Defense Authorization Act for Fiscal Year 1996, Pub. L. No. 104-106, $\S 1342,110$ Stat. 186,486 .

205. See Ntakirutimana v. Reno, 184 F.3d 419 (5th Cir. 1999).

206. Id. at 426 . The majority cited, of all things, Tribe's AMERICAN CONSTITUTIONAL LAW.

207. Id. at 436 (DeMoss, J., dissenting). Judge DeMoss also pointed out that the expansion of the extradition statute to include the Rwanda and former Yugoslavia tribunals had occurred via a last-minute attachment to non-relevant legislation, without any hearings, committee consideration, or floor debate of the provisions. For scholarly discussion of the Ntakirutimana case, see Evan J. Wallach, Extradition to the Rwandan War Crimes Tribunal: Is Another Treaty Required?, 3 UCLA J. INT'L L. \& FOREIGN AFF. 59 (1998); Panayiota Alexandropoulos, Note, Enforceability of Executive-Congressional Agreements in Lieu of an Article II Treaty for Purposes of Extradition: Elizaphan Ntakirutimana v. Janet Reno, 45 VILLA. L. REV. 107 (2000). 
Environment. In addition to extradition, the President and Senate have used the treaty process for most of the nation's significant environmental agreements. ${ }^{208}$ While perhaps not as crucial to national security as alliances or arms control, international environmental treaties may represent the most legislation-like agreements in their setting of norms for domestic private conduct. The United States has entered into agreements limiting pollution, such as the Montreal Protocol, which accelerated the retirement of certain chemicals that harmed the ozone layer, ${ }^{209}$ and the Convention on Transboundary Pollution, ${ }^{210}$ which seeks to reduce cross-border air pollution, all by the treaty process. Agreements that protect certain environments, such as the Antarctic region ${ }^{211}$ or outer space, ${ }^{212}$ or endangered species, such as whales, polar bears, migratory birds, and seals, ${ }^{213}$ also have undergone approval by a supermajority of the Senate. More ambitious regulatory agreements, such as the U.N. Convention on Climate Change, also have undergone the treaty process. ${ }^{214}$ As with human rights treaties, Presidents have agreed to submit these pacts to the Senate even when they could have avoided significant opposition by resorting to the twohouse procedure. ${ }^{215}$ Presidents have delayed the submission of controversial environmental agreements, such as agreements that would require the nation to protect biodiversity and to restrict its energy use

208. See United Nations Framework Convention on Climate Change, done May 9, 1992, S. TreatY DoC. No. 102-38 (1992), 31 I.L.M. 849; The Antarctic Treaty, Dec. 1, 1959, 12 U.S.T. 794, 402 U.N.T.S. 71.

209. Montreal Protocol on Substances that Deplete the Ozone Layer, adopted June 29, 1990, 30 I.L.M. 537; Vienna Convention for the Protection of the Ozone Layer, opened for signature Mar. 22, 1985, 26 I.L.M. 1516. 1442

210. Convention on Long-Range Transboundary Air Pollution, Nov. 13, 1979, 18 I.L.M.

211. See The Antarctic Treaty, supra note 208.

212. See Treaty on Principles Governing the Activities of States in the Exploration and Use of Outer Space, Including the Moon and Other Celestial Bodies, done Jan. 27, 1967, 18 U.S.T. 2410, 610 U.N.T.S. 205.

213. See Agreement on the Conservation of Polar Bears, done Nov. 15, 1973, 27 U.S.T. 3918, 13 I.L.M. 13; Convention for the Conservation of Antarctic Seals, June 1, 1972, 29 U.S.T. 441, 11 I.L.M. 251; Benelux Convention Concerning Hunting and the Protection of Birds, June 10, 1970, 847 U.N.T.S. 255; International Convention for the Protection of Birds, Oct. 18, 1950, 638 U.N.T.S. 185; International Convention for the Regulation of Whaling, Dec. 2, 1946, 62 Stat. 1716, 161 U.N.T.S. 72.

214. See United Nations Framework Convention on Climate Change, supra note 208.

215. President Reagan declined to sign the United Nations Convention on the Law of the Sea, Oct. 7, 1982, and hence prevented Congress from considering the agreement. If the theory of interchangeability were correct, Congress could have enacted the Law of the Sea Convention in the face of presidential opposition. International agreements involving the oceans, however, seem to follow no clear principle. Some agreements involving the rules that apply at sea have been done as statutes, see, e.g., Convention for the Unification of Certain Rules with Respect to Assistance and Salvage at Sea, Sept. 23, 1910, 37 Stat. 1658, 1 Bevans 780 , while others have been done as treaties, see, e.g., Convention on the High Seas, done Apr. 29, 1958, 13 U.S.T. 2312, 450 U.N.T.S. 82. 
and industrial pollution, because of likely Senate opposition. ${ }^{216} \mathrm{Al}$ though President Reagan decided against submitting to the Senate one of the most significant international environmental agreements, the Law of the Sea Convention, there is little doubt that the agreement would have been formalized as a treaty, rather than a congressionalexecutive agreement. ${ }^{217}$

Examination of postwar practice by the political branches thus reveals a manageable line between treaties and congressional-executive agreements. The President and Senate have used the statutory process to approve agreements that generally involve international trade and economics. These subjects fall within Congress's Article I, Section 8 power over international commerce and often require modification of existing statutory law to bring the United States into compliance. The President and Senate, it appears, still reserve certain classes of subjects for the treaty process, primarily national security, arms control, human rights, and the environment. These areas bear important constitutional differences from international economics and commerce. ${ }^{218}$ Subjects such as national security and arms control, for example, fall primarily within the President's plenary powers as Commander-in-Chief and sole organ of the nation in its foreign relations. ${ }^{219}$ They also involve concurrent powers on the part of Congress, such as those of appropriations and of declaring war. After City of Boerne v. Flores, ${ }^{220}$ which invalidated Congress's effort to extend broader protections for relig-

216. See Convention on Biological Diversity, done June 5, 1992, S. TREATY DOC. NO. 103-20 (1993), 31 I.L.M. 818; United Nations Framework Convention on Climate Change, supra note 208.

217. President Clinton, for example, submitted the Convention follow-on agreements to the Senate for approval as a treaty. See Bernard H. Oxman, The Law of the Sea Convention, ASIL Newsletter (Nov.-Dec. 1994).

218. Tax treaties might seem to be the exception that disproves this rule. Tax is certainly a matter of international economics and commerce, and yet our agreements with other nations on taxation usually assume the treaty form. It appears, however, that tax treaties do not apply domestically of their own force - in other words, they are non-self-executing. Rather, Congress has chosen to implement tax treaty obligations through provisions of the Internal Revenue Code. See I.R.C. $\$ \S 894,7852$ (d) (2000). Moreover, Congress regularly overrides tax treaty obligations through its normal tax statutes. See generally David Sachs, Is the 19th Century Doctrine of Treaty Override Good Law for Modern Day Tax Treaties?, 47 TAX LAW. 867 (1994) (examining the tax-treaty-override doctrine and arguing for its termination or modification). This practice indicates that the political branches have continued to use legislation, rather than treaties alone, to regulate international economics and commerce that would usually fall within Congress's Article I powers. For an examination of current international tax treaty issues, see, for example, Reuven S. Avi-Yonah, The Structure of International Taxation: A Proposal for Simplification, 74 TEX. L. REV. 1301 (1996); Julie Roin, Rethinking Tax Treaties in a Strategic World with Disparate Tax Systems, 81 VA. L. REV. 1753 (1995).

219. See generally John C. Yoo, The Continuation of Politics by Other Means: The Original Understanding of the War Powers, 84 CAL. L. REV. 167 (1996) [hereinafter Yoo, War Powers].

220. 519 U.S. 1088 (1997) (finding Religious Freedom Restoration Act to lie outside of Congress's enforcement powers under Section 5 of the Fourteenth Amendment). 
ious freedom beyond those established by the Constitution, the implementation of the substantive terms of human rights treaties may rest outside of Congress's enumerated powers as well. ${ }^{221}$ It is unclear what congressional power could justify extradition - the seizure of persons because of their alleged acts in foreign countries, regardless of their involvement in interstate or international commerce - due to the lack of an explicit enumerated power. Environmental law straddles the line between treaties and congressional-executive agreements - while some environmental matters rest within Congress's powers over interstate commerce, others (especially more recent environmental agreements addressing energy use or biodiversity) might not, in light of the recent restrictions on the Commerce Clause imposed by the Supreme Court. ${ }^{222}$

Consistent use of the treaty process for certain classes of international agreements undercuts the most compelling justification for the internationalist and transformationist accounts. Practice simply cannot be explained by either theory. If the two instruments were utterly interchangeable, as both groups of scholars would have it, then one would expect the President to send most international agreements through the two-house procedure because of the easier chances of passage. Instead, practice indicates that there was no constitutional moment that removed the Senate from the role of making international agreements, that there was no consensus accepting "codification" of the ascendancy of the congressional-executive agreement, and that something more complex is going on in the growing use of the congressional-executive agreement. Rather than interchangeability, the political branches have followed significant distinctions between congressional-executive agreements and treaties.

The history of international agreement-making also undermines the central claim of the internationalist camp. There has been neither a long pedigree of complete interchangeability, nor a recent practice of completely substituting statutes for treaties. President Wilson could not have used a statute to enact the Treaty of Versailles because the idea never would have occurred to him - the legislative method of agreement-making did not exist. President Clinton could not have submitted the failed comprehensive Nuclear Test Ban Treaty as a congressional-executive agreement, because he would have violated

221. Indeed, one leading international law scholar has suggested that the only way to achieve such goals is now through the Treaty Clause, which Missouri v. Holland, 252 U.S. 416 (1920), has indicated is not limited by the same federalism considerations that apply to Congress. Gerald L. Neuman, The Nationalization of Civil Liberties, Revisited, 99 CoLUM. L. REV. 1630, 1644 (1999) ("Those treaties create international obligations that Congress has the authority to implement under the Necessary and Proper Clause in conjunction with the treaty power.").

222. See, e.g., United States v. Morrison, 529 U.S. 528 (2000); United States v. Lopez, 514 U.S. 549 (1995). 
the constitutional understanding that has reserved all arms control agreements for supermajority approval in the Senate. Neither history nor practice, however, provides refuge for the treaty exclusivist. Congressional-executive agreements, despite their relatively youthful pedigree, have come to dominate international agreements covering a wide variety of fields. Part III will explore the theoretical reasons why the President, Senate, and Congress have reserved different subjects for different instruments of agreement-making. For the moment, the next Section completes the critique of existing scholarly theories by illuminating the constitutional distortions created by interchangeability.

\section{B. Structural Problems Created by Interchangeability}

This Section will examine the textual and structural inconsistencies created by interchangeability. First, interchangeability distorts the allocation of powers among the branches in the area of foreign affairs. By transferring agreement-making power from the executive branch (the President and Senate acting in their Article II capacity) to Congress, the President's authority in foreign affairs is diminished and domestic regulation becomes unmoored from the Constitution's lawmaking processes. Second, interchangeability allows a class of statutes to escape the structural limitations, such as the separation of powers and federalism, that restrict congressional power. Because of its location in Article II, treaties have been free from the processes and restrictions that govern statutes. If congressional-executive agreements were fully interchangeable with treaties, statutes logically would assume the broader sweep of treaties. These points will become clear after comparing the process of making statutes with the process of making treaties.

\section{Congressional-Executive Agreements and the Foreign Affairs Power}

Interchangeability's most obvious distortion of the constitutional structure lies in the weakening of the President's formal foreign affairs powers. Article II, Section 2 declares that the President makes treaties, subject to the advice and consent of two-thirds of the Senate. The President, not the Senate, chooses to initiate the treaty process, and the President can still refuse to make a treaty even after the Senate has approved it. ${ }^{223}$ A statutory process for making international agreements threatens to oust the President from this constitutionally dominant position and effectively negates the President's absolute

223. See HENKIN, Foreign AFFAIRS, supra note 6, at 184. 
veto over foreign policy. ${ }^{224}$ If the agreement takes the form of a public law, then Congress can initiate the process without presidential approval, just as it can propose any statute without his consent. Even if the President unequivocally opposes an agreement and vetoes it, Congress can choose to override the presidential veto by a two-thirds vote. These structural implications of interchangeability conflict with the Constitution's centralization of foreign affairs power in the executive branch. Under United States $v$. Curtiss-Wright Export Corp. ${ }^{225}$ as well as long executive and legislative practice reaching to the very beginnings of the Republic, ${ }^{226}$ the President is constitutionally responsible for the conduct of foreign policy. Creating an alternate process for making international agreements, one that excludes the President, would allow Congress to pursue its own foreign policy and interfere with the executive's leadership role. This would radically alter the constitutional structure of the foreign affairs power. ${ }^{227}$

Interchangeability further warps the President's foreign affairs powers after the public lawmaking process ends. Statutes require the consent of both houses of Congress and the President, or two-thirds of Congress without the President, before they can be repealed. Although the Constitution does not address the issue, today most commentators, courts, and government entities believe that the President may terminate a treaty unilaterally. ${ }^{228}$ The President retains this authority due to his dominant constitutional position in foreign affairs $^{229}$ and his structural superiority in conducting international relations. If the nation were to regulate certain domestic conduct by statute, the President could not terminate the rules without congressional approval. If the nation were to regulate the same conduct in concert with a treaty, however, the President enjoys the power to terminate

\section{See Tribe, supra note 14 , at 1253.}

225. 299 U.S. 304 (1936).

226. See, e.g., Thomas Jefferson to Edward Charles Genet, Nov. 22, 1793, in 27 PAPERS OF THOMAS JEFFERSON 414 (John Catanzariti ed. 1997) (stating that the President is the "only channel of communication" between United States and foreign nations); John Marshall, Speech Before House of Representatives, 10 ANNALS OF CONG. 613 (1800) (arguing that the President is "sole organ" of nation in its communications with foreign nations).

227. See Tribe, supra note 14 , at 1255.

228. See Goldwater v. Carter, 617 F.2d 697, 708-09 (D.C. Cir.), vacated as moot, 444 U.S. 996 (1979); RESTATEMENT (THIRD), supra note 7, at $\$ 339$; HENKIN, FOREIGN AFFAIRS, supra note 6 , at 214 . Some once thought that breaking treaties required the consent of twothirds of the Senate. See Stefan A. Riesenfeld, The Power of Congress and the President in International Relations: Three Recent Supreme Court Cases, 25 CAL. L. REV. 643, 658-65 (1937).

229. The D.C. Circuit, for example, upheld President Carter's unilateral termination of the Taiwan treaty due to both the President's role as the constitutional representative of the nation in its foreign affairs and his plenary authority over recognition of foreign governments. See Goldwater, 617 F.2d at 705-08. 
the regulation at will. Interchangeability, however, upsets this structure in either one of two ways. On the one hand, it could mean that Congress can bind the nation to an international agreement that the President could not terminate unilaterally, which would represent a serious curtailment of the executive's foreign affairs powers. On the other hand, defenders of interchangeability might allow the President the same ability to terminate congressional-executive agreements as to terminate treaties. This, however, would provide the President with the heretofore unknown power of executive termination of statutes. ${ }^{230}$ This would be tantamount to granting the President a direct share of the legislative power - a result, as Professor Henry Monaghan has argued, that is at odds with our understanding of the executive power. ${ }^{231}$

Termination raises another problem for the interchangeability of treaties and statutes. Under the "last in time" rule, the consensus view is that treaties may trump earlier statutes, and that subsequent statutes can override earlier treaties. ${ }^{232}$ Allowing treaties and statutes to terminate each other in this way runs counter to the formalist approach to lawmaking articulated by the Supreme Court in INS v. Chadha. ${ }^{233} \mathrm{~A}$ decision to repeal earlier legislation, as was the ca se with the use of the legislative veto in Chadha, requires a new law. The last-in-time rule seems to violate this principle by allowing the treatymakers to counteract an earlier action by the President, Senate, and House. Interchangeability allows international agreements to override previous statutes. In discussing this possibility, Madison rejected it out of hand during the Jay Treaty debates because "it involved the absurdity of an Imperium in imperio; [or] of two powers both of them supreme, yet each of them liable to be superseded by the other." ${ }^{234}$ Although Madison admitted that the Roman constitution had operated similarly, he believed that it was only a "political phenomenon, which had been celebrated as a subject of curious speculation only, and not as a model for the institutions of any other Country." 235 In Madison's mind, vest-

230. Indeed, many believe that, at a minimum, the very purpose of the Take Care Clause was to prevent the President from enjoying this power. See Calabresi \& Prakash, supra note 44 , at $549-50$.

231. The constitutional text resists the notion that an "independent, free-standing presidential law-making authority exists insofar as the rights of American citizens are concerned." Henry P. Monaghan, The Protective Power of the Presidency, 93 CoLUM. L. REV. 1, 4 (1993).

232. See Whitney v. Robertson, 124 U.S. 190, 194 (1888); Chae Chan Ping v. United States, 130 U.S. 581, 600 (1889) (The Chinese Exclusion Case); Edye v. Robertson, 112 U.S. 580,599 (1884) (The Head Money Cases); HENKIN, FoREIGN AFFAIRS, supra note 6, at 20911.

233. 462 U.S. 919 (1983).

234. Speech by James Madison on Jay's Treaty (Mar. 10, 1796), in 16 PAPERS OF JAMES MADISON 255, 257 (J.C.A. Stagg et al. eds. 1989) [hereinafter MADISON PAPERS].

235. Id. 
ing the legislative power in two separate authorities that could "annul the proceedings of the other" would produce only an unstable and irrational government. ${ }^{236}$

\section{Interchangeability and the Lack of Limits on the Treaty Power}

Interchangeability further undermines the Constitution's basic structure by allowing Congress to escape the restrictions on its enumerated powers. If the statutory process is a perfect substitute for the Treaty Clause, then congressional-executive agreements must enjoy the same constitutional benefits that accrue to the treaty form. This result has important implications for both the separation of powers and federalism, because most internationalist scholars argue that much of the structural elements of the Constitution do not apply with the same force to treaties as to domestic laws.

Under standard internationalist theories, interchangeability could allow statutes to enjoy the less stringent application of the separation of powers to treaties. This could happen in one of two ways. First, treaties could transfer powers among the branches, or create hybrid forms of government power, that would prove unconstitutional if undertaken solely by domestic law. In United States v. Curtiss-Wright Export Corp. ${ }^{237}$ for example, the Court observed that the nondelegation doctrine would not apply with the same force in foreign affairs, a proposition the Court recently re-affirmed in Clinton v. New York. ${ }^{238}$ Some have argued further that treaties are limited, at best, only by "radiations" from the separation of powers. ${ }^{239}$ Second, the treatymakers could delegate authority that normally resides with the executive or judicial branches to international organizations. ${ }^{240}$ Under standard internationalist doctrine, a treaty could transfer authority from Congress to the executive branch or to an international organization, as some argue that the U.N. Charter actually does, ${ }^{241}$ when a statute could not. Theoretically, interchangeability allows statutes to enjoy

236. Id.

237. 299 U.S. 304 (1936).

238. 524 U.S. 417 (1998).

239. HENKIN, FOREIGN AFFAIRS, supra note 6, at 195.

240. Some scholars even maintain that a treaty could "bargain away" Congress's authority to declare war by allowing war to be triggered automatically under certain events. See id. at 196.

241. See Thomas M. Franck \& Faiza Patel, UN Police Action in Lieu of War: "The Old Order Changeth," 85 AM. J. INT'L L. 63 (1991); but see Michael J. Glennon \& Allison R. Hayward, Collective Security and the Constitution: Can the Commander in Chief Power Be Delegated to the United Nations?, 82 GEO. L.J. 1573 (1994) (arguing that UN. Security Council resolutions cannot provide domestic legal authorization for war). For a criticism of the ability of the United States to delegate command authority over U.S. troops to U.N. or foreign command, see Yoo, Kosovo, supra note 125, at 1708-20. 
the loosened restrictions that would apply to treaties in these situations.

Used in these ways, congressional-executive agreements can undermine the separation of powers in both of its inter-branch aspects. First, suppose that a statute required the transfer of law enforcement or judicial power to an international agency or tribunal. Officials of the international body would not generally be removable by the President, because the very point of creating international regulatory institutions often is to free them from the direct influence of different nation-states. ${ }^{242}$ Even under the loose standards of Morrison v. Olson ${ }^{243}$ or Mistretta $v$. United States, ${ }^{244}$ a domestic effort by Congress to completely shield individuals who exercise executive authority from presidential removal would fall afoul of either the Appointments Clause, the Article II vesting clause or the Take Care Clause, while efforts to transfer the federal judicial power might violate Article III's vesting clause. Yet, some international and constitutional law scholars argue that such standards should not apply to international agreements because they involve foreign affairs. ${ }^{245}$ Second, if statutes are to enjoy the same status as treaties, and if treaties are not subject to the usual structural constraints of the separation of powers, then presumably Congress could restructure the separation of powers when acting through the congressional-executive agreement, even though it could not with an identical statute that concerned domestic affairs.

Interchangeability also threatens to allow Congress to exercise powers that, if exercised domestically, would violate federalism limitations. Before the Rehnquist Court's reinvigoration of federalism, the generous interpretation given to the Commerce Clause relieved the government of relying upon the broad extent of the treaty power for its actions. In recent years, however, the Supreme Court has placed new limits upon the extent of the federal government's powers. Following up on United States v. Lopez, ${ }^{246}$ the Court last Term struck down the Violence Against Women Act as beyond the Commerce Clause because it regulated a noneconomic activity. ${ }^{247}$ In Alden $v$.

242. See Yoo, New Sovereignty, supra note 125, at 91-96 (discussing creation of Chemical Weapons Convention Technical Secretariat); Kenneth W. Abbott, "Trust But Verify": The Production of Information in Arms Control Treaties and Other International Agreements, 26 CORNELL INT'L L.J. 1, 57 (1993) (discussing benefits of neutral international organizations).

243. 487 U.S. 654 (1988).

244. 488 U.S. 361 (1989)

245. See, e.g., Harold H. Bruff, Can Buckley Clear Customs?, 49 WASH. \& LEE L. REV. 1309 (1992); William J. Davey, The Appointments Clause and International Dispute Settlement Mechanisms: A False Conflict, 49 WASH. \& LEE L. REV. 1315 (1992).

246. 514 U.S. 549 (1995).

247. See United States v. Morrison, 529 U.S. 598 (2000). 
Maine, the Court concluded that Congress could not use its Article I, Section 8 powers to override state sovereign immunity in either federal or state court. ${ }^{248}$ In Printz v. United States ${ }^{249}$ and New York $v$. United States, ${ }^{250}$ the Court held that Congress could not use its Commerce Clause powers to "commandeer" state executives or legislatures. And in City of Boerne v. Flores, ${ }^{251}$ College Savings Bank of Florida v. Florida, ${ }^{252}$ and Kimel v. Florida Board of Regents, ${ }^{253}$ the Court invalidated federal statutes that had attempted to redefine individual rights at variance with the Court's own interpretation of the Bill of Rights and the Fourteenth Amendment. In these cases, the Court has sought both to place limits on Congress's enumerated powers and to expand the protections for state sovereignty.

Interchangeability provides the lawmakers with a way to avoid these recent restrictions on their powers. According to both standard internationalist thought and Supreme Court case law, treaties are not subject to the same federalism limitations that bind statutes. As a textual matter, the Constitution locates treaties in Article II, which implies that they need not live within the same boundaries that contain Article I. Leading commentators therefore assert that the treatymakers can make policy on any subject, even where the lawmakers would be prevented from doing so by Article I, Section 8's enumeration of limited congressional powers or the Tenth Amendment's reservation of powers to the states. ${ }^{254}$ According to Professor Henkin, "[u]nlike the delegations to Congress which give it authority over enumerated substantive areas of national policy, the treaty power is authority to make national policy (regardless of substantive content) by international means and process for an international purpose."255 Internationalists read the Tenth Amendment as inapplicable to the treaty power, because they view the broad scope of treaties as part of the powers expressly delegated to the federal government by the Constitution. Anything that the treaty power can extend to is, by definition, excluded from the Tenth Amendment. Concludes Professor Henkin, "[m]any matters, then, may appear to be 'reserved to the States' as regards domestic legislation if Congress does not have power to regulate them; but they are not reserved to the states so as to exclude their

248. 527 U.S. 706 (1999).

249. 521 U.S. 898 (1997).

250. 505 U.S. 144 (1992).

251. 521 U.S. 507 (1997).

252. 527 U.S. 666 (1999).

253. 528 U.S. 62 (2000).

254. See, e.g., RESTATEMENT (ThIRD), supra note 7, at $\$ \S 302-03$; HeNKIN, FOREIGN AFFAIRS, supra note 6, at 190-93.

255. HENKIN, FOREIGN AfFAIRS, supra note 6, at 191. 
regulation by international agreement."256 This argument, we are told, is "clear and indisputable,"257 although it has been the subject of a vigorous debate recently between Professors Curtis Bradley and David Golove in this Law Review over whether the same federalism limitations ought to apply to both statutes and treaties. ${ }^{258}$

In Missouri v. Holland, ${ }^{259}$ the Supreme Court expressed agreement with the notion that the normal limits on the legislative power do not apply to treaties. Holland raised the question of whether Congress had authority to enact the Migratory Bird Treaty Act of 1918, which implemented a 1916 treaty between the United States and Great Britain that protected certain birds flying between the United States and Canada. The treaty barred the hunting or capture of any of the birds protected by the treaty, a substantive action that the federal courts at the time had held lay outside Congress's Commerce Clause powers. ${ }^{260}$ In an opinion by Justice Holmes, the Court rejected the idea that the Tenth Amendment's limitations on Congress's powers also applied to the treaty power. Conceding that the Commerce Clause did not include the power to regulate migratory birds, Justice Holmes concluded that the treaty did not violate "any prohibitory words to be found in the Constitution," nor did it conflict with "some invisible radiation from the general terms of the Tenth Amendment." ${ }^{261}$ The Treaty Power, according to the Court, was not to be limited in the same manner as Congress's powers under Article I, Section 8 , because the treaty concerned "a national interest of very nearly the first magnitude," the power over which had to be vested somewhere in the national government. ${ }^{262}$ As the Court declared, "[i]t is obvious that there may be matters of the sharpest exigency for the national well being that an act of Congress could not deal with but that a treaty followed by such an act could." ${ }^{263}$ While the Court later limited Holland in the individual rights context in Reid v. Covert, ${ }^{264}$ it has yet to identify restrictions emanating from the separation of powers or federalism.

Holland's expansive reading of the treaty power suggests the structural distortions caused by interchangeability. At least in regard to the

256. Id. at 191 (footnote omitted).

257. Id.

258. See Curtis A. Bradley, The Treaty Power and American Federalism, $97 \mathrm{MICH}$. L. REv. 390, 394 (1998); David Golove, Treaty-Making and the Nation: The Historical Foundations of the Nationalist Conception of the Treaty Power, 98 MicH. L. REV. 1075 (2000).

259. 252 U.S. 416 (1920).

260. See id. at 432 (citing lower court decisions).

261. Id. at 433-34.

262. Id. at 435.

263. Id. at 433.

264. 354 U.S. 1 (1957). 
Commerce Clause, Holland makes some sense, because the Treaty Power is an executive one located in Article II, Section 2, which logically is not subject to the limitations that apply to legislative power in Article I. This clause becomes, however, a structural loophole if one accepts the argument that congressional-executive agreements are completely interchangeable with treaties. If such statutes can take the place of treaties, and if treaties are not subject to the regular federalism limitations that apply to laws, then interchangeability exempts congressional-executive agreements from the limitations imposed by Article I, Section 8 and the Tenth Amendment. Interchangeability, in other words, creates a subclass of statutory law that is somehow free from the restrictions that apply to all other statutes.

Interchangeability provides yet a third way for statutes to escape the normal limitations on their scope. Treaties, many believe, are not subject to subject matter limitations in the same manner as statutes. Under the internationalist approach, the United States can enter into a treaty on any subject, so long as it is "an agreement between two or more states or international organizations that is intended to be legally binding and is governed by international law." "265 Drawn from international law, this definition contains no subject-matter limitations. As everyday life becomes more closely intertwined with international events, systems, trends, and markets, and treaties involve not just military alliances, but individual rights, environment, finance and commerce, and crime, it will become even more difficult to cordon off a domestic sphere that shall remain immune from international agreement. If internationalists correctly argue that international agreements can be made on virtually any subject, and if internationalists and transformationists are correct that congressional-executive agreements and treaties are fully interchangeable, then statutes that embody international agreements can regulate virtually any subject. Lawmakers would be able to enact statutes that are not limited in subject-matter, are not limited by Article I, Section 8's enumeration of powers, and are not limited by the Tenth Amendment or federalism. Interchangeability provides the lawmakers with an almost unrestricted authority to legislate on any subject. ${ }^{266}$

265. RESTATEMENT (THIRD), supra note 7, at $\$ 301$. Section 301 tracks the definition of a treaty from Article 1 of the Vienna Convention on the Law of Treaties, which the United States has not ratified.

266. While complete interchangeability creates severe textual and structural distortions in constitutional law, the alternate theory of treaty exclusivity is open to other significant doubts. Treaty exclusivity proves as equally unable as interchangeability in accounting for the practice of the political branches in making international agreements. If treaty exclusivity were correct, the United States should never have entered into the Bretton Woods agreements immediately after World War II, or the more recent string of free trade agreements such as NAFTA and the WTO. Further, if exclusivity is to be applied in the future, America's entry into NAFTA and the Uruguay Round of GATT are unconstitutional and could be successfully challenged by appropriate plaintiffs in federal court. Concluding that 


\section{TOWARD A THEORY OF CONGRESSIONAL-EXECUTIVE}

\section{AGREEMENTS}

As the previous Parts have shown, the leading academic theories have failed to provide a satisfying account of the current American practice toward international agreements. Defenders of interchangeability sacrifice constitutional coherence - maintaining the structural integrity of the Constitution while giving each of its provisions force in order to provide a limitless flexibility to the political branches. Treaty exclusivists, on the other hand, seek a stricter adherence to the constitutional text and structure, but at the price of rejecting recent practice, including the legitimacy of the GATT and NAFTA agreements. These two approaches seem to set up a classic conflict between the Constitution and expediency.

This Article will now develop an approach that preserves the constitutionality of significant international agreements that take the statutory form, without causing interchangeability's severe textual and structural distortions. We can reconcile constitutional text with modern demands by recognizing the distinction drawn by the political branches themselves. Congress can resort to congressional-executive agreements in areas over which Congress already possesses plenary constitutional authority, such as international trade and finance. Treaties, however, still remain the required instrument of national policy when the federal government reaches international agreements on matters outside of Article I, Section 8, or over which the President and Congress possess concurrent and potentially conflicting powers. As I have argued elsewhere, treaties may still be concluded in areas of Congressional authority, but such treaties must be non-self-executing, in order to preserve the Constitution's separation of the executive and legislative powers. The theory developed here is consistent with, and

\footnotetext{
the treaty constitutes the only method whereby the United States can enter into international agreements would require us to find that about 80 percent of all of the United States' current international obligations are constitutionally invalid. Just as interchangeability cannot recognize the distinctions that the political branches apparently have drawn between treaties and congressional-executive agreements, treaty exclusivity similarly would sweep aside that line in favor of declaring that all agreements must undergo the treaty form.

Naturally, proponents of treaty exclusivity shy away from such revolutionary implications. Professor Tribe, for example, seeks to save NAFTA and the WTO from the implications of treaty exclusivity through a functional approach. NAFTA and the Uruguay Round agreement, he argues, are still legitimate ex post because they received more than a twothirds vote of approval in the Senate. Tribe, supra note 14 , at $1227 \mathrm{n} .18$ \& 1276 . If a congressional-executive agreement received enough supermajoritarian political support to have survived as a treaty, Tribe suggests, we should consider it as a constitutional treaty. This effort to play fast-and-loose with the Constitution's categories for lawmaking suffers from clear flaws. If agreements such as NAFTA and the WTO are to remain constitutional, American foreign relations law requires a different theory of congressional-executive agreements that stands on firmer footing.
} 
shares the main objectives of, my work defending the doctrine of nonself-executing treaties.

This approach conveys several advantages over interchangeability and treaty exclusivity. It respects the constitutional text and structure while also acknowledging recent practice and the importance of agreements such as GATT and NAFTA. It maintains the Constitution's principle of limited, enumerated powers and its protection for the sovereignty of the states, as articulated by recent Supreme Court opinions. It honors the Constitution's separation of powers, specifically the distinction between the legislative and executive powers, by reserving for legislation matters within Article I, Section 8, and for the executive treaty power issues outside of those areas. Finally, this theory of international agreements makes sense of several apparent inconsistencies in the constitutional structure produced by treaties and interchangeability: treaty initiation and termination, treaty implementation and non-self-execution, and the scope of treaties and federalism.

Section $\mathrm{A}$ argues that congressional-executive agreements make sense as an effort to preserve a clear line between the executive and legislative powers. Section B draws support for this reading from the Constitution's text, structure, and history. Section C suggests how this theory of congressional-executive agreements and treaties works out in practice.

\section{A. A Theory of Congressional-Executive Agreements}

A theory of congressional-executive agreements should take as its starting point the distinction drawn by the political branches themselves. As discussed earlier, the executive and legislative departments have consistently used statutes to enter into international agreements that address international economic affairs, such as trade agreements, international financial institutions, and the like. Despite the alleged constitutional moment in 1945, the President and Senate have reserved the treaty form for significant international obligations in several areas, such as political/military agreements, arms control, extradition, the environment, and human rights. Examples where the political branches have overstepped this line are rare.

In observing this distinction, the political branches appear to be honoring the Constitution's basic division of the executive and legislative powers. The treaty power is an executive power that rests in Article II, as distinguished from a legislative authority vested in Congress in Article I, Section 8. Congressional-executive agreements may be used in the arena of international economic affairs because Congress has plenary authority over the area under the Foreign Commerce Clause. If, for example, Congress were to adopt unilaterally the changes in tariffs, customs laws, or national treatment required by 
NAFTA or the WTO, in the absence of an international agreement, it would have ample authority to do so pursuant to Article I, Section 8 .

Not only are congressional-executive agreements acceptable, but in areas of Congress's Article I, Section 8 powers, they are - in a sense - constitutionally required. In order to respect the Constitution's grant of plenary power to Congress, the political branches must use a statute to implement, at the domestic level, any international agreement that involves economic affairs. Otherwise, the mere presence of an international agreement would allow the treatymakers to assume the legislative powers so carefully lodged in Article I for Congress. Because internationalists generally believe that most treaties automatically become federal law without implementing legislation, ${ }^{267}$ interchangeability produces precisely this incongruity. ${ }^{268}$ Congressional-executive agreements preserve Congress's Article I, Section 8 authority over matters such as international and interstate commerce, intellectual property, criminal law, and appropriations, by requiring that regardless of the form of the international agreement, Congress's participation is needed to implement obligations in those areas.

Intellectual property protections under recent international trade agreements illustrate this point. Before the Uruguay Round of the GATT, regulation of the length of patents was a matter of domestic law. Congress established the period of patents under its plenary Article I, Section 8 power to "promote the Progress of Science and useful Arts, by securing for limited Times to Authors and Inventors the exclusive Right to their respective Writings and Discoveries." ${ }^{269}$ Under an 1861 law, patent terms in the United States ran seventeen years from the time a patent application received approval. Part of the WTO agreement, Article 33 of the Agreement on Trade-Related Aspects of Intellectual Property Rights, altered that term of patent protection to twenty years from the time of the filing of a patent application. ${ }^{270}$ Just as Congress would have used a statute to change the term

267. See generally, e.g., Martin S. Flaherty, History Right?: Historical Scholarship, Original Understanding, and Treaties as "Supreme Law of the Land," 99 COLUM. L. REV. 2095 (1999) (defending the internationalist view); Carlos Vázquez, Laughing at Treaties, 99 COLUM. L. REV. 2154 (1999) (same).

268. I have argued elsewhere that the text, structure, and history of the Constitution suggest that the better reading is that most treaties require congressional participation - via implementing legislation - to take effect in domestic courts. Non-self-execution, as this doctrine is known, respects - as does the theory of congressional-executive agreements presented here - the distinctions between international agreements and domestic law, and between the executive treaty power and the legislative power. See generally Yoo, Globalism, supra note 8 (arguing that original understanding supports doctrine of non-self-executing treaties); Yoo, Non-Self-Execution, supra note 10 (arguing that text and structure justify non-self-execution).

269. U.S. CONST. art. I, $\S 8$, cl. 8

270. Agreement on Trade-Related Aspects of Intellectual Property Rights, Apr. 15, 1994, art. 33, Marrakesh Agreement Establishing the World Trade Organization, Annex 1C, 
of patent protection unilaterally, it used the same instrument to alter domestic laws in accordance with our international obligations. ${ }^{271}$

Under a theory of treaty exclusivity, however, the only way for the United States to have implemented this change was through a supermajority vote of the Senate. Indeed, exclusivity would require the use of the treaty process even though Congress possesses ample authority to alter patent terms under its plenary constitutional powers. Congress could even adopt the twenty-year term unilaterally to bring the United States into harmony with an international agreement that it has not joined. But, according to exclusivists, if the nation were to enter into a formal agreement that achieved the exact same result in substantive law, the federal government must use the treaty form. Further, if one adheres to the doctrine of self-executing treaties, treaty exclusivity requires that such a treaty be able to override Congress's power to set the length of patents. As treaties are an executive power under Article II, this result allows the executive branch to exercise legislative powers vested by the Constitution in Congress alone.

Using congressional-executive agreements in areas of plenary congressional authority avoids this constitutional conflict. Whether Congress adopts the new twenty-year period as part of an international agreement or as merely a change in domestic policy, the instrument is the same: a statute that receives the support of simple majorities in both houses of Congress and the signature of the President. This approach, which follows the doctrine of treaty non-self-execution, implies that the treatymakers could choose to make a treaty on a subject within Congress's Article I powers. This theory, however, also requires that such a treaty be without domestic effect until implemented by Congress. In the end, both the treaty and congressional-executive route would still require a statute to make changes in domestic law within areas under Congress's Article I competence, thereby preserving congressional authority under Article I.

Viewing congressional-executive agreements in this way helps clarify the line that separates statutes from treaties. Allowing treaties to expand into areas regulated by Article I, Section 8 would undermine the constitutional structure by excluding the most direct popular representatives in the national government from exercising their control over areas given specifically to Congress. On the other hand, as Part II argued, allowing congressional-executive agreements to reach areas outside of Article I, Section 8's enumeration of powers would undermine the Constitution's vesting of a limited legislative power in the federal government. With the growing internationalization of do-

LEGAL INSTRUMENTS - RESULTS OF THE URUGUAY ROUND vol. 31, 33 I.L.M. 81, 96 (1994) [hereinafter TRIPs Agreement].

271. Congress created an alternative method for calculating patent terms under in the Uruguay Round Agreements Act. See 35 U.S.C. \& 154 (1994). 
mestic affairs, merely asserting a foreign relations link or the need to comply with a multilateral international agreement would prove too large a loophole for expansive congressional powers. Allowing treaties directly to regulate subjects outside of congressional powers, while limiting congressional-executive agreements to matters given to the legislature alone by Article I, Section 8, would prevent international agreements from distorting the Constitution's public lawmaking system.

Following this approach would avoid the severe federalism concerns raised by interchangeability. Due to the special role of the Senate, which has a unique interest in defending state prerogatives, the treaty process provides greater political safeguards for the states than the regular statutory process. ${ }^{272}$ Even though the Court's reinvigoration of federalism in the last decade has substantially undermined (if not overruled) Garcia v. San Antonio Metropolitan Transit Authority, ${ }^{273}$ the idea that the structure of the national government provides significant protection for state sovereignty has special force with the Treaty Clause. Unlike the statutory process, which some scholars believe already provides sufficient political safeguards for federalism, ${ }^{274}$ the treaty process requires a supermajority vote in the Senate. Only a constitutional amendment or the override of a presidential veto demand as high a degree of consensus in the Senate. This requirement presumably provides federalism interests with even greater protection with regard to a treaty than a statute, not only because one-third plus one of the Senate can stop a treaty, but also because these Senators can represent an even smaller percentage of the population. Protection of state institutional interests was one of the very reasons why the Framers preserved the Articles of Confederation's supermajority requirement for treaties. ${ }^{275}$ It seems that practice has borne out these intentions, as the Senate has proceeded to attach "federalism" reservations to several recent treaties, limiting their reach to that already possessed by the national government. ${ }^{276}$

Treaties usually involve matters of foreign affairs that are of great national importance, over which the Constitution already centralizes power in the national government. Putting to one side the serious

272. See CHOPER, supra note 74 , at $174-84$. While I have criticized the political safeguards of federalism argument, it was on the ground that the theory erred in claiming that the safeguards excluded judicial review, not on the notion that the structure of the national political process itself protects federalism. John Yoo, The Judicial Safeguards of Federalism, 70 S. CAL. L. REV. 1311, 1380-81 (1997).

273. 469 U.S. 528 (1985).

274. See, e.g., CHOPER, supra note 74, at 176; Larry D. Kramer, Putting the Politics Back into the Political Safeguards of Federalism, 100 COLUM. L. REV. 215, 233-78 (2000) (arguing that history supports this view).

275. See Yoo, Globalism, supra note 8, at 2009-13, 2029-32.

276. See id. at 1973-76. 
doubts of legal scholars, ${ }^{277}$ the Court has observed in cases such as United States v. Curtiss-Wright Export Corp. ${ }^{278}$ United States v. Belmont, ${ }^{279}$ and United States v. Pink ${ }^{280}$ that the Constitution's transfer of all of the foreign affairs power to the federal government may have relieved the states of any cognizable interests when international relations are involved. ${ }^{281}$ National sovereignty in international relations may allow the federal government to exercise broader powers, vis-àvis the states, than it could domestically. Even in foreign affairs areas not specifically delegated to the federal government by the Constitution, as Justice Sutherland asserted in Curtiss-Wright, the states may have been completely ousted because of the need to unify national sovereignty in the federal government. As Justice Sutherland later wrote in Belmont, "[g]overnmental power over internal affairs is distributed between the national government and the several states. Governmental power over external affairs is not distributed, but is vested exclusively in the national government." ${ }^{282}$ While this nationalist view of the foreign affairs power is not free from doubt, the approach developed here would allow such exercises of national sovereignty to occur through the treaty power, whose supermajority requirement in the Senate and the limitations of non-self-execution would harmonize it with the constitutional structure.

This analysis finds that the domestic area open to control only by treaty is the class of subjects that rests outside of Congress's Article I, Section 8 powers. While the reach of the Commerce Clause has expanded enormously since the New Deal, United States v. Morrison demonstrates that there are still some matters that Congress cannot

277. See Charles Lofgren, United States v. Curtiss-Wright Export Corporation: An Historical Reassessment, 83 YALE L.J. 1 (1973); Michael D. Ramsey, The Power of the States in Foreign Affairs: The Original Understanding of Foreign Policy Federalism, 75 NOTRE DAME L. REV. 341 (1999).

278. 299 U.S. 304 (1936).

279. 301 U.S. 324 (1937).

280. 315 U.S. 203 (1942).

281. The absence of constitutional federalism interests on the part of the states in foreign affairs, however, does not answer the question of what presumption is to be applied in the absence of an affirmative federal action by the political branches. When the political branches have chosen not to use their foreign affairs powers, then general federalism considerations may re-emerge. Jack Goldsmith has argued that the underpinnings for a dormant federal foreign affairs pre-emption doctrine are accordingly weak. See generally Jack L. Goldsmith, Federal Courts, Foreign Affairs, and Federalism, 83 VA. L. REV. 1617 (1997). He also has claimed, with his co-author Curtis Bradley, that federal courts are also limited in creating a federal common law that incorporates customary international law norms. See Curtis A. Bradley \& Jack L. Goldsmith, Customary International Law as Federal Common Law: A Critique of the Modern Position, 110 HARV. L. REV. 815 (1997); Curtis A. Bradley \& Jack L. Goldsmith, Federal Courts and the Incorporation of International Law, 111 HARV. L. REV. 2260 (1998).

282. 301 U.S. at 330. 
regulate under the Commerce Clause. ${ }^{283}$ City of Boerne v. Flores makes clear that Congress's Section 5 enforcement powers under the Fourteenth Amendment cannot expand definitions of individual constitutional rights. ${ }^{284}$ Printz $^{285}, \mathrm{New}$ York ${ }^{286}$, Seminole Tribe ${ }^{287}$, and Al$d e n^{288}$ rule out use of the Commerce Clause to overcome certain aspects of state sovereignty. Nevertheless, Missouri v. Holland indicates that these areas may still be subject to Article II's treaty power, even if Congress could not use its Article I powers to pass a domestic statute on the matter. ${ }^{289}$ Commentators have been troubled by Holland's expansive language because it seems to assert without any textual basis that the federal government can act outside of its enumerated powers. ${ }^{290}$ In fact, Holland makes sense as an accommodation of the executive treaty power and Article I's vesting of all of the federal legislative power in Congress. While treaties should not be self-executing in areas of plenary congressional authority, they should reach areas that lie outside of congressional powers due to Article I or Tenth Amendment limits. ${ }^{291}$ Giving treaties this scope prevents them from infringing upon Congress's enumerated powers, while also respecting Article VI's grant of supremacy effect to treaties over state law. ${ }^{292}$

This theory explains why the political branches have refused to use congressional-executive agreements to enter into international human rights conventions. Interchangeability cannot prevail because of the constitutional limitations on Congress's enumerated powers to expand the definition of individual rights that apply against the states. Several treaties that the United States has ratified alter the definition of certain individual rights contrary to Supreme Court decisions. For example, the International Covenant on Civil and Political Rights prohibits the death penalty for crimes committed when the criminal offender was under the age of eighteen. ${ }^{293}$ Supreme Court precedent, however, permits states to execute juvenile offenders for crimes committed as young as sixteen years old. ${ }^{294}$ That same treaty sets international stan-

283. 120 S. Ct. 1740 (2000).

284. 521 U.S. 507 (1997).

285. Printz v. United States, 521 U.S. 898 (1997).

286. New York v. United States, 505 U.S. 144 (1992).

287. Seminole Tribe of Fla. v. Florida, 517 U.S. 44 (1996).

288. Alden v. Maine, 527 U.S. 706 (1999).

289. 252 U.S. $416(1920)$.

290. See, e.g., Bradley, supra note 258 , at 394 (arguing that federalism limits should be placed on the "plenary" treaty power).

291. See Yoo, Non-Self-Execution, supra note 10, at 2249-57.

292. See id. at 2244.

293. International Covenant on Civil and Political Rights, supra note 185, at art. 6(5).

294. See Stanford v. Kentucky, 492 U.S. 321 (1978). 
dards against cruel, inhumane, or degrading treatment while in prison that go beyond the Court's reading of the Eighth Amendment. ${ }^{295}$ Other agreements, such as the International Convention on the Elimination of All Forms of Racial Discrimination, which prohibits racial hate speech, ${ }^{296}$ similarly would expand individual rights beyond the Court's interpretation of the Bill of Rights. ${ }^{297}$

It was once thought that Congress had some authority under Section 5 of the Fourteenth Amendment to participate in the definition of the substance of individual constitutional rights. ${ }^{298}$ City of Boerne, however, made clear that Congress could not use its Section 5 powers to pursue a definition of constitutional rights at variance with the decisions of the Court. ${ }^{299}$ While we may live in an age when many important rights are guaranteed by statute, City of Boerne still forbids Congress from interfering in areas where the Court has refused to recognize broader constitutional protections. At most, Congress may enact only non-substantive, remedial statutes that bear a certain congruence and proportionality to violations of constitutional rights by the states. ${ }^{300}$ As Professor Gerald Neuman has recently suggested, however, this limitation on congressional authority may not apply to the treaty power due to Missouri v. Holland. ${ }^{301}$ The treaty power, Justice Holmes indicated, was not just a different procedure for the exercise of Article I's enumerated power, but was an independent source of substantive power.

295. See Michael H. Posner \& Peter J. Spiro, Adding Teeth to United States Ratification of the Covenant on Civil and Political Rights: The International Human Rights Conformity Act of 1993, 42 DePaul L. REV. 1209, 1216-17 (1993).

296. International Convention on the Elimination of All Forms of Racial Discrimination, supra note 188, art. 4, S. EXEC. DOC. C, 95-2, at 1, 3-4, 660 U.N.T.S. at 218-220 (prohibiting hate speech). The Supreme Court has found racial hate speech to be protected by the Free Speech Clause of the First Amendment. R.A.V. v. St. Paul, 505 U.S. 377 (1992).

297. Several other multilateral human rights treaties similarly would expand individual rights beyond what the Court has permitted. The Convention on the Rights of the Child, supra note 193, would provide children with substantive and procedural rights that they currently lack. The Court has held that family law remains the preserve of state regulation. Hisquierdo v. Hisquierdo, 439 U.S. 572, 581 (1979). Similarly, the Convention on the Elimination of All Forms of Discrimination Against Women, supra note 190, which the United States has signed but not ratified, also would extend gender discrimination rules to areas that have been considered the preserve of the states. See Bradley, supra note 258, at 403.

298. Katzenbach v. Morgan, 384 U.S. 641, 646-47 (1966). See generally Jesse H. Choper, Congressional Power to Expand Judicial Definitions of the Substantive Terms of the Civil War Amendments, 67 MiNN. L. REV. 299 (1982).

299. 521 U.S. 507 (1997). Recent cases, such as United States v. Morrison's invalidation of the Violence Against Women Act, 529 U.S. 598 (2000), and College Savings Bank's limitation on federal remedies for intellectual property, College Sav. Bank v. Florida Prepaid Postsecondary Educ. Expense Bd., 527 U.S. 666 (1999), demonstrate that City of Boerne was no one-time event. See also Kimel v. Florida Bd. of Regents, 528 U.S. 62 (2000).

300. Boerne, 521 U.S. at 529-36.

301. Neuman, supra note 221, at 1644-45. 
If Missouri $v$. Holland remains good law, then the political branches theoretically can use the treaty power to reach the same result as the Religious Freedom Restoration Act ("RFRA"), without being limited by Section 5 of the Fourteenth Amendment or the Commerce Clause. Rather than altering the meaning of the Constitution, as interpreted by the Supreme Court, Congress would merely be implementing a treaty. Indeed, Professor Neuman has argued that provisions of the International Convention on Civil and Political Rights already create the treaty hook necessary to pass another version of RFRA. ${ }^{302}$ Federal regulation of other areas may also require the treaty form in order to benefit from Missouri v. Holland's sweep. United States $v$. Lopez, for example, indicates that Congress can use its Commerce Clause powers only to regulate activity that either is in interstate commerce, is an instrumentality of interstate commerce, or substantially effects interstate commerce if commercial itself in nature. ${ }^{303}$ Last Term's United States $v$. Morrison re-emphasized this limit. Some environmental protection measures thus might encounter constitutional difficulties if undertaken solely by Congress's Commerce Clause power. Current treaties that protect endangered species might fall outside the Court's current approach to the Commerce Clause, ${ }^{304}$ as might proposed treaties that would protect biodiversity and establish national quotas for energy use. Only the Treaty Clause might supply a certain source of power to regulate in these areas. ${ }^{305}$

Treaties also might be necessary in areas over which the executive and legislative branches have concurrent or overlapping powers. Because unilateral action by one branch cannot bind the other branch as a constitutional matter, the nation may need to assume an international obligation by treaty in order to commit both branches. Not surprisingly, different elements of the foreign affairs powers may be the area where treaties are most necessary. As Professor Koh has observed, the Constitution often delegates different powers over the same foreign affairs issue to the two political branches, without specifying the relationship between those powers. ${ }^{306}$ War powers provide a

302. See Neuman, supra note 52 , at $49-50$. The Senate, however, declared the treaty nonself-executing when it gave its advice and consent, which might bar congressional efforts to use the ICCPR as authority for a second-generation RFRA statute. This result would occur not because of a constitutional defect in the scope of the treaty power, but because of the manner in which the Senate approved the treaty.

303. 514 U.S. 549 (1995).

304. See Bradley, supra note 258, at 408.

305. Cf. Gavin R. Villareal, Note, One Leg to Stand On: The Treaty Power and Congressional Authority for the Endangered Species Act After United States v. Lopez, 76 TEX. L. REV. 1125 (1998) (suggesting that treaty power represents the best weapon for defenders of congressional power to enact the Endangered Species Act).

306. See $\mathrm{KOH}$, supra note 6 , at 67 ("One cannot read the Constitution without being struck by its astonishing brevity regarding the allocation of foreign affairs authority among the branches."). 
ready example. The Constitution gives the President the Commanderin-Chief power and the undefined executive power, while vesting in Congress the sole power to declare war and to raise and fund the military. Yet, the constitutional text does not clearly state which branch has the authority to initiate military hostilities. This gap has led me to argue elsewhere that no constitutionally prescribed method exists for going to war, but instead that the branches may use their plenary powers either to cooperate or to compete for primacy. ${ }^{307}$ While the President may use the Commander-in-Chief power to send troops into conflict, Congress may deny him or her the operational or financial means to engage in hostilities; Congress, however, cannot force the President to send troops into certain conflicts or deploy them in certain ways. Neither branch can engage in unilateral action that will result in the sustained commitment of the United States to make war as part of a political or military alliance. A treaty, in contrast, allows both branches with a say to commit themselves to such long-term international obligations.

We may therefore expect treaties to be used in areas where the branches possess concurrent powers that require cooperation rather than unilateral congressional or presidential action - for their consistent exercise. Political/military alliances and arms control are areas where the participation of both the President and a supermajority of the Senate may be necessary because of the competing allocation of foreign affairs power. The United States, for example, could not live up to its obligations under the North Atlantic Treaty alliance through the unilateral actions of the executive or legislature alone. To be sure, the President could station troops in Europe under the Commanderin-Chief power, and even order them into conflict on his own authority. ${ }^{308}$ Nonetheless, the President has required congressional participation to guarantee that the nation could raise, properly equip, and fund the large, permanent military forces that have guarded Europe for more than fifty years. While Congress could pass a statute creating those armies, it could not constitutionally force the President to deploy them to Europe..$^{309}$ The treaty form provides the appropriate means to fulfill the nation's obligations under the NATO treaty, because it represents the promise of both the President and a supermajority of the upper house of the legislature to meet demanding, longterm obligations.

307. Yoo, War Powers, supra note 219, at 296-02; see also John C. Yoo, Clio at War: The Misuse of History in the War Powers Debate, 70 U. COLO. L. REV. 1169, 1171-73 (1999); Yoo, Kosovo, supra note 125, at 1687.

308. See generally Yoo, War Powers, supra note 219. Even if one did not agree that Presidents can send the military into hostilities without a declaration of war, one might believe that they could do so pursuant to treaty or even international law obligations. See Yoo, Kosovo, supra note 125, at 1719-28 (discussing and criticizing this argument).

309. See Yoo, War Powers, supra note 219. 
Or consider arms control agreements. In the Intermediate-Range Nuclear Forces treaty with the Soviet Union, the United States agreed to remove an entire class of nuclear weapons from deployment and to cease production and refrain from any future flight-testing of certain missiles and launchers. ${ }^{310}$ Implementation of this treaty required both branches to cooperate in the use of their constitutional authorities. The Commander-in-Chief power controlled the placement and use of existing missiles such as the Pershing II, which President Reagan had deployed to Western Europe in the early 1980s, as well as the potential conversion of other weapons systems into intermediate-range weapons. Legislative participation was necessary to guarantee that Congress would not authorize or fund the development of future intermediate-range nuclear weapons. A similar analysis may be applied to the START treaties, which require the elimination of some existing nuclear weapons and the commitment to ceilings on American nuclear force structures. ${ }^{311}$ Contrast these treaties with a trade agreement such as NAFTA or the WTO. Congress could bring domestic law into compliance with NAFTA or the WTO in the absence of any agreement, or even in the face of presidential opposition. For trade, a congressionalexecutive agreement, or statute, is all that is needed..$^{312}$

\section{B. Solving the Conflict Between Articles I and II}

This Article's analysis of international agreements does more than explain the subject-matter-based distinction drawn by practice between congressional-executive agreements and treaties. It also solves many of the severe distortions in the constitutional text and structure wrought by interchangeability and treaty exclusivity. On the one hand, as we have seen, interchangeability allows the legislative power not only to subsume executive functions, but also to escape the limitations imposed by Article I, Section 8. Treaty exclusivity, on the other hand, ultimately fails because it creates irreconcilable conflicts between the treaty power and the legislative power. Although the treaty power fundamentally remains an executive one, several developments such as the rise of globalization, the doctrine of self-execution, and relaxed structural limits on treaties - threaten to give the treaty power a sweeping legislative dimension. Executive assumption of legislative power assaults the Constitution's vesting of all legislative power in Congress, and it undermines constitutional structures that promote popular sovereignty.

310. Treaty between the United States of America and the U.S.S.R. on the Elimination of Their Intermediate-Range and Shorter-Range Missiles, supra note 170.

311. See The START II Treaty, supra note 176; The START I Treaty, supra note 176.

312. Other areas within the President's Article Il powers may be handled by a sole executive agreement, such as international claims settlement. 
Congressional-executive agreements avoid this conflict by continuing to reserve to the legislature the power to regulate those areas given to it under Article I, Section 8, but allowing ample room for treaties to operate outside that field. This Part will develop this approach by examining the original understanding of the treaty power and its relationship to the legislative power, by demonstrating how the congressional-executive agreement has actually served to defend the federal legislative power from encroachment by the executive, and by showing how this theory of international agreements harmonizes with the American public lawmaking system.

\section{The Original Understanding}

Maintaining a line between statutes and treaties finds support in the original understanding of the Constitution. Separation of the legislative and executive powers underlay the Framers' general approach to the constitutional allocation of the foreign affairs power. A century of struggle between Crown and Parliament had taught the framing generation that the power to legislate served as an important check upon the executive's activities in foreign affairs. ${ }^{313}$ They continued this distinction, established by the British constitution, during the revolutionary period, culminating in the division of the treaty and legislative powers during the drafting and ratification of the Constitution. While this Article is not the place to conduct a thorough review of the constitutional history of foreign affairs during the British colonial and early national periods, ${ }^{314}$ several episodes illustrate the Framers' understanding that the legislative power and the treaty power were to occupy separate spheres in domestic law.

First, by the middle of the eighteenth century, the British political and constitutional system had established the norm that treatymaking and domestic lawmaking were to remain distinct and separate. Familiar authorities on the British constitution, such as John Locke, Montesquieu, and William Blackstone, envisioned a foreign affairs power vested in the executive that could not exercise the authority to establish domestic rules of conduct, which they considered the essence of the legislative power. ${ }^{315}$ Both Locke's and Montesquieu's separation

313. See Yoo, Globalism, supra note 8, at 1982-2091 (reviewing evidence from the original understanding regarding the difference between the legislative and treaty powers).

314. I have attempted such a study elsewhere, see id., although in regard to the different question of self-executing treaties. Professors Martin Flaherty and Carlos Vázquez have criticized different aspects of this historical analysis, see generally Flaherty, supra note 267; Vázquez, supra note 267, to which I have responded in Yoo, Non-Self-Execution, supra note 10 , at 2221-33.

315. See JoHn Locke, THE SECOND TREATISE OF CIVIL GOVERNMENT $§ \S 143-47$ (J.W. Gough ed., Basil Blackwell 1947) (1690); 1 M. DE SECONDAT, BARON DE MONTESQUIEU, SPIRIT OF THE LAWS, bk. 11, ch. 6, at 196-210 (trans., 4th ed. 1768) (1748); 1 WILLIAM BLACKSTONE, COMMENTARIES *160-*161, *252-*253, *257,*270. 
of powers theories, which defined the function of representing the nation in its international relations as distinct from that of enacting rules of conduct, and Blackstone's balanced government approach, which saw the legislative power as a check on the executive, established that the foreign affairs power was not to intrude upon the legislative authority. Recent British political history reinforced these lessons. During the struggles between Crown and Parliament in the seventeenth century, the latter had successfully used its exclusive powers over funding and legislation to control the King's efforts in treatymaking. ${ }^{316}$ By the time of the framing, the British political system had reached a constitutional settlement in which the Crown's exclusive prerogative over treatymaking was checked by Parliament's absolute authority to make domestic law. This accommodation became a central element of the British Constitution's system of checks and balances and of the rise of parliamentary government.

Second, experience during the colonial and revolutionary period confirmed that the foreign affairs power and domestic legislation were to remain separate spheres. Mirroring the division of powers between King and Parliament, London unilaterally controlled the external powers of war and treaty, while avoiding interference with the colonial assemblies' management of internal affairs. ${ }^{317}$ From a constitutional perspective, one can view the American Revolution as the colonies' rejection of London's efforts to use its foreign affairs power to assume more direct legislative power. With the Revolution, Americans transferred the Crown's imperial powers to the Articles of Confederation Congress, while the legislative power remained dispersed among the states. ${ }^{318}$ Just as the Crown required Parliament's consent to fund and implement treaties, so too the Continental Congress remained powerless to legislate directly without state cooperation. This division of authority produced debilitating foreign affairs crises, such as the failure by the states to honor the 1783 Treaty of Peace with Great Britain,

316. Yoo, Globalism, supra note 8, at 1997-04. Summarizing the British approach to treaties and public lawmaking, English legal historian Frederick Maitland observed: "Suppose the queen contracts with France that English iron or coal shall not be exported to France - until a statute has been passed forbidding exportation, one may export and laugh at the treaty." F.W. MAITLAND, THE CONSTITUTIONAL HISTORY OF ENGLAND 425 (H.A.L. Fisher ed., 1961) (1908); see also id. at 424-25; 10 SIR WILLIAM HOLDSWORTH, A HISTORY OF ENGLISH LAW 373-74 (1938); 11 id. at 253, 268.

317. See, e.g., Bernard Bailyn, The Ideological Origins of the American REVOlution 217-29 (1967); JACK P. GREENE, PERIPHERIES AND CENTER: CONSTITUTIONAL DEVElopment IN THE EXTENDED POLITIES OF THE BRITISH EMPIRE AND THE UNITED STATES 1607-1788, at 19-43 (1986); JOHN PHILliP ReID, CONSTITUTIONAL HISTORY OF THE AMERICAN REVOLUTION: THE AUTHORITY TO LEGISLATE 126-41 (1991).

318. See JERrilyn GREenE MARSTON, KING AND CONGRESS: THE TRANSFER OF Political LegitimaCY, 1774-1776, at 303-04 (1987); Eugene R. Sheridan \& John M. Murrin, Introduction to CONGRESS AT PRINCETON: BEING THE LETTERS OF CHARLES THOMSON TO HANNAH THOMSON JUNE-OCTOBER 1783, at xi, xxxiv-xxxviii (Eugene R. Sheridan \& John M. Murrin eds., 1985). 
which led many of the Framers to seek a stronger national government. ${ }^{319}$ While some, such as John Jay and Alexander Hamilton, believed that the answer was to give all treaties self-executing effect as domestic law, others such as James Madison sought to create a truly national legislative power that could implement treaties directly. ${ }^{320} \mathrm{Be}-$ cause "a unanimous and punctual obedience of thirteen independent bodies, to the acts of the federal Government, ought not be calculated on," Madison wrote in a memo just before the Philadelphia Convention, the national government needed the power to operate directly upon individuals without the intervention of the States. ${ }^{321}$

Evidence from the ratification of the Constitution further indicates that the treaty power was not to intrude into Congress's legislative authority. When the Constitution went to the States, Anti-Federalists initially seized on the Treaty and Supremacy Clauses for improperly vesting legislative power in an aristocratic body like the Senate. ${ }^{322}$ George Mason's influential Objections to the Constitution echoed the claims of other widely publicized Anti-Federalists writers, such as the "Federal Framer" and "Brutus": "By declaring all Treaties supreme Laws of the Land, the Executive \& the Senate have, in many Cases, an exclusive Power of Legislation ...."323 In order to maintain the separation of lawmaking and treatymaking, Mason argued, the approval of the House of Representatives ought to be necessary before any treaty could have legislative effect. Anti-Federalists repeated similar claims in significant ratification conventions in Pennsylvania and Virginia. ${ }^{324}$

Federalists responded throughout the ratification process that the separation of the legislative power in Article I from the treaty power in Article II would respect the traditional Anglo-American distinction between treaties and laws. In Pennsylvania, James Wilson answered the Anti-Federalist charges by referring to the Crown's need to seek parliamentary cooperation in any treaties that changed domestic laws.

319. See FREDERICK W. MARKS III, INDEPENDENCE ON TRIAL: FOREIGN AFFAIRS AND THE MAKING OF THE CONSTITUTION 52-95 (1973).

320. See Yoo, Globalism, supra note 8, at 2016-24.

321. See Vices of THE POlitical SySTEM OF THE UNITEd STATES (Apr. 1787), reprinted in 9 PAPERS OF JAMES MADISON 345, 351 (Robert A. Rutland et al. eds., 1975).

322. See Yoo, Globalism, supra note 8, at 2040-43; see, e.g., GEORGE MASON, MASON'S OBJECTIONS TO THE CONSTITUTION OF GOVERNMENT FORMED BY THE CONSTITUTION (Oct. 7,1787 ), reprinted in 13 THE DOCUMENTARY HISTORY OF THE RATIFICATION OF THE CONSTITUTION 348, 350 (John P. Kaminski \& Gaspare J. Saladino eds. 1981) [hereinafter DOCUMENTARY HISTORY].

323. MASON, supra note 322, at 350; see also LETTER IV FROM THE FEDERAL FARMER (Oct. 12, 1787), reprinted in 14 DOCUMENTARY HISTORY, supra note 322, at 42, 43-44; BRUTUS II (Nov. 1, 1787), reprinted in 13 id. at 524, 529.

324. Yoo, Globalism, supra note 8, at 2043-48, 2059-68. 
He then asked "And will not the same thing take place here?"325 In New York, Alexander Hamilton as Publius argued that treaties were not legislative in nature:

The essence of the legislative authority is to enact laws, or in other words, to prescribe rules for the regulation of the society; while the execution of the laws and the employment of the common strength, either for this purpose or for the common defence, seem to comprise all the functions of the executive magistrate. The power of making treaties is, plainly, neither the one nor the other. It relates neither to the execution of the subsisting laws nor to the enaction of new ones; and still less to an exertion of the common strength. Its objects are CONTRACTS with foreign nations which have the force of law, but derive it from the obligations of good faith. They are not rules prescribed by the sovereign to the subject, but agreements between sovereign and sovereign. The power in question seems therefore to form a distinct department, and to belong properly neither to the legislative nor to the executive. ${ }^{326}$

Hamilton's co-author followed a similar line in the all-important Virginia ratifying convention. Managing the response to AntiFederalist leaders Patrick Henry, Mason, and James Monroe, Madison circulated talking points that urged Federalist delegates to emphasize the House's control over domestic legislation. "It is true that this branch is not of necessity to be consulted in the forming of Treaties," Madison admitted, but nonetheless its "approbation and co-operation may often be necessary in carrying treaties into full effect." ${ }^{327}$ Because of the House's monopoly over funding and legislation, Madison argued, it would have the same check on treaties that Parliament enjoyed in Great Britain. "[A]s the support of the Government and of the plans of the President \& Senate in general must be drawn from the purse which [the House of Representatives] hold[s]," he explained, "the sentiments of this body cannot fail to have very great weight, even when the body itself may have no constitutional authority."328 Relying upon these arguments in the convention debates, Madison and his Federalist colleague, George Nicholas, answered AntiFederalist concerns by analogizing the practical workings of the national government to the British system, in which the House of Com-

325. The Pennsylvania Convention (Dec. 11, 1787), in 2 DOCUMENTARY HISTORY, supra note 322 , at 550,563 .

326. THE FEDERALIST No. 75 (Alexander Hamilton), reprinted in id. at 481, 482.

327. Letter from James Madison to George Nicholas (May 17, 1788), in id. at 804, 808.

328. Id; see also id. at 809 ("[U]nder the new System every Treaty must be made by 1 . the authority of the Senate in which the States are to vote equally. 2. that of the President who represents the people \& the States in a compounded ratio. and 3. under the influence of the H. of Reps. who represent the people alone."). 
mons' control over domestic law "gives them such influence that [it] can dictate in what manner [treaties] shall be made." 329

Two other pieces of evidence from the Framing period also suggest that those who ratified the Constitution understood that the treaty power could not infringe on Congress's legislative powers. First, toward the end of the ratification debates in the press, some leading Anti-Federalists appeared to accept the arguments of Wilson, Hamilton, and Madison. One of the earliest critics of the Treaty Clause, the Federal Farmer, moderated his public views later in the debate. "On a fair construction of the constitution," he wrote in a subsequent set of essays, "I think the legislature has a proper controul over the president and senate in settling commercial treaties." ${ }^{330}$ Recognizing that the treaty power and Congress's power over international commerce could come into conflict, the Federal Farmer observed that:

As to treaties of commerce, they do not generally require secrecy, they almost always involve in them legislative powers, interfere with the laws and internal police of the country, and operate immediately on persons and property, especially in the commercial towns: (they have in GreatBritain usually been confirmed by Parliament;) they consist of rules and regulations respecting commerce; and to regulate commerce, or to make regulations respecting commerce, the federal legislature, by the constitution, has the power. I do not see that any commercial regulations can be made in treaties, that will not infringe upon this power in the legislature; therefore, I infer, that the true construction is, that the president and senate shall make treaties; but all commercial treaties shall be subject to be confirmed by the legislature. This construction will render the clauses consistent, and make the powers of the president and senate, respecting treaties, much less exceptionable. ${ }^{331}$

Consensus between Federalists and Anti-Federalists on how to harmonize the Treaty Clause and Congress's plenary powers should not be taken lightly. In accepting Federalist arguments about the limited nature of the treaty power, the Federal Farmer essentially adopted the same view that Federalists had used to prevail in the major ratifying states. Because treaties could not exercise Congress's legislative powers, the most populous branch enjoyed the means to check the designs of the treatymakers.

Second, experience during the early years of the Republic suggests that the political branches accepted this reading of the constitutional structure. In 1795, the Senate approved the controversial Jay Treaty, which settled several outstanding issues causing friction in Anglo-

329. George Nicholas, Debates - The Virginia Convention, June 13, 1788, in $10 \mathrm{id}$. at 1228 , 1251; see Yoo, Globalism, supra note 8, at 2059-68 (recounting Virginia ratifying convention's debates on Treaty Clause).

330. LeTter FROM THE FEDERAL FARMER XI, May 2, 1788, reprinted in 17 DOCUMENTARY HISTORY, supra note 322, at 301, 309.

331. Id at 309-10. 
American relations. ${ }^{332}$ Parts of the Jay Treaty involved appropriations as well as the treatment of British shipping and goods. ${ }^{333}$ Federalists argued that Congress had a constitutional duty to implement the treaty; the treaty power, leaders such as Alexander Hamilton argued, could exercise any power delegated to Congress in Article I. In the "Defence," Hamilton claimed that "[e]ach house of Congress collectively as well as the members of it separately are under a constitutional obligation to observe the injunctions of a [treaty] and to give it effect." ${ }^{334}$ Assisted by the new Jeffersonian congressmen Albert Gallatin, Madison reiterated the theory he had propounded during the ratification - that the treaty power remained limited by Congress's legislative authority - and turned to the original understanding itself for support. Speaking before the House, Madison declared that he

would only appeal to the Committee [of the Whole] to decide whether it did not appear, from a candid and collected view of the debates in those Conventions, and particularly in that of Virginia, that the Treaty-making power was a limited power; and that the powers in our Constitution, on this subject bore an analogy to the powers on the same subject in the Government of Great Britain. He wished, as little as any member could, to extend the analogies between the two Governments; but it was clear that the constituent parts of two Governments might be perfectly heterogeneous, and yet the powers be similar. ${ }^{335}$

Following Madison's lead, the House resolved, fifty-seven to thirtyfour, that "when a Treaty stipulates regulations on any of the subjects submitted by the Constitution to the power of Congress, it must depend, for its execution, as to such stipulations, on a law or laws to be passed by Congress." 336

To be sure, the Framers could not have anticipated the great explosion in international agreements today, nor could they have foreseen the leading role that America would take in world affairs. They did, however, consider the potential conflict between making treaties

332. See Treaty of Amity, Commerce and Navigation, supra note 200. The policy and politics of the Jay Treaty are discussed in SAMUEL FLAGG BEMIS, JAY'S TREATY: A STUDY IN COMMERCE AND DiplomaCY (rev. ed. 1962) (1923); JERALD A. COMBS, THE JAY TREATY: POLITICAL BATTLEGROUND OF THE FOUNDING FATHERS (1970); and ELKINS \& MCKITRICK, supra note 66, at 375-449.

333. See David P. Currie, The Constitution In Congress: The Federalist PERIOD 1789-1801, at 210-17 (1997) (providing a description of the constitutional debates in Congress over the Jay Treaty).

334. Alexander Hamilton, The Defence No. XXXVI (Jan. 2, 1976), reprinted in 20 The Papers of Alexander Hamilton 3, 4 (Harold C. Syrett ed., 1974) [hereinafter THE HAMILTON PAPERS]. Hamilton argued that reading the treaty power as limited by congressional authority would make it impossible for the nation to enter into treaties. See also AleXANDER HAMILTON, THE DeFENCE No. XXXVII (Jan. 6, 1796), reprinted in 20 id. at $13,16-22$.

335. 5 ANNALS OF CONG. 777 (1796).

336. Id. at 771 . 
binding upon the nation, in a way that they had not been under the Articles of Confederation, and vesting the federal legislative power in Congress alone. The Framers resolved this tension by returning to the traditional Anglo-American separation between legislating and treatymaking. Current practice by the political branches concerning congressional-executive agreements honors this original understanding. While the branches continue to use treaties in areas of congressional incompetence or overlapping executive and legislative powers, they have used the statutory process to enact international agreements that involve Congress's core Article I, Section 8 powers. This arrangement maintains the balance between the executive and legislative branches, and it ensures that the people's most direct representatives have the primary hand in enacting domestic rules of conduct.

\section{Congressional-Executive Agreements as a Defense of the Legislative Power}

Reserving areas within Article I, Section 8's ambit for approval by congressional-executive agreement, rather than by treaty, preserves textual and structural elements of the Constitution and promotes the original understanding. Consider the ramifications of an alternate approach that would make treaties the exclusive method for making international agreements. First, treaties remain an executive power that excludes the branch most directly accountable to the people, the House of Representatives. Second, unlike statutes, treaties have no defined subject matter, which means that the treatymakers can enter into an international agreement on any matter, regardless of whether the Constitution grants control over it to another branch. Third, most internationalist legal scholars believe that treaties are generally selfexecuting - if their terms are clear, treaties do not require implementing legislation by Congress, but instead are to be automatically enforced by the courts. ${ }^{337}$ Congressional-executive agreements, on the other hand, promote democracy by infusing foreign policymaking with House participation. Their use guarantees that the same lawmaking process will apply to laws that have the same effect in regulating domestic conduct.

337. See, e.g., HENKIN, FOREIGN AFFAIRS, supra note 6, at 201; Lori Fisler Damrosch, The Role of the United States Senate Concerning "Self-Executing" and "Non-Self-Executing" Treaties, in PARLIaMENTARY PARTICIPATION IN THE MAKING AND OPERATION OF TREaties: A Comparative STUdy 205, 217-18 (Stefan A. Riesenfeld \& Frederick M. Abbott eds., 1994); Flaherty, supra note 267; Jordan J. Paust, Self-Executing Treaties, 82 AM. J. INT'L L. 760, 760 (1988); Stefan A. Riesenfeld, The Doctrine of Self-Executing Treaties and U.S. v. Postal: Win at Any Price?, 74 AM. J. INT'L L. 892, 896-901 (1980); Carlos Manuel Vázquez, Treaty-Based Rights and Remedies of Individuals, 92 COLUM. L. REV. 1082, 111314, 1121-22 (1992). 
Because of its placement in Article II, the treaty power remains an executive power. Some have read Article II to constitute a broad grant of power because of Article III's parallel vesting clause and Article I's narrower, enumerated vesting clause. ${ }^{338}$ In keeping with this observation, the powers enumerated in Article II, Section 2, such as the powers to command the military, to issue pardons, and to execute the laws, must be (and traditionally have been considered to be), executive in nature. When Article II includes the Senate in the operation of these functions, such as the making of treaties or the appointment of federal judges and officers, it does not transform these clauses into legislative powers.

The Senate's inclusion in treatymaking and appointments - powers held exclusively by the British Crown - represents instead an effort to dilute the unitary nature of the executive branch. ${ }^{339}$ In this respect, the treaty power's division between President and Senate reflected the practice of the Revolution-era state constitutions, which had sought to control executive power not by re-allocating to the legislature the powers of war, peace, and appointment, but by disrupting the unity and independence of the executive branch. ${ }^{340}$ While the Constitution may reduce executive power in favor of the legislature when compared with the British constitution, it nowhere transfers what were considered legislative powers to Article II.

This is not to say that the executive branch does not enjoy some legislative power. When the Constitution, however, grants the President a power that is legislative in nature, it does so in Article I, not Article II. Thus, the Constitution grants the President a conditional veto over legislation in Article I, Section 7, not Article II, Section 2. While no one can deny that the executive branch also makes law through administrative regulations, this lawmaking occurs due to the delegation of authority by Congress, subject to clear and manageable standards. ${ }^{341}$ Similarly, when the federal courts exercise lawmaking authority, under Erie Railroad Co. v. Tompkins, ${ }^{342}$ this interstitial gap-

338. See Calabresi \& Prakash, supra note 44, at 570-71 (claiming that the vesting clause creates a reservoir of unenumerated executive power). But see Lessig \& Sunstein, supra note 132 (taking a contrary view); Flaherty, supra note 132 (same).

339. This point was first made by Alexander Hamilton in his "Pacificus" essays defending the constitutionality of President Washington's Neutrality Proclamation. See, e.g., ALEXANDER HAMILTON, PACIFICUS No. I (June 29, 1793), reprinted in 15 THE HAMILTON PAPERS, supra note 334, at 33, 39.

340. See Yoo, War Powers, supra note 219, at 222-28; Willi Paul Adams, The FIRST AMERICAN CONSTITUTIONS: REPUBLICAN IDEOLOGY AND THE MAKING OF THE STATE CONSTITUTIONS IN THE REVOLUTIONARY ERA 271-75 (Rita \& Robert Kimber trans., 1980) (1973); Charles C. Thach, JR., The Creation of THE PresidenCy 1775-1789: A Study IN CONSTITUTIONAL HISTORY 34-54 (1922).

341. See Clinton v. New York, 524 U.S. 417, $442-47$ (1998); Mistretta v. United States, 488 U.S. 361,372 (1989).

342. 304 U.S. 64 (1938). 
filling role must be authorized by federal law. ${ }^{343}$ The Constitution delineates the President's lawmaking role in Article I, rather than Article II, because Article I contains the finely balanced method for making federal laws. The Constitution centralizes all public lawmaking into such a tortuous process specifically to make the exercise of legislative authority more difficult, thereby protecting the states and the people from unwarranted exercises of federal power ${ }^{344}$ Hence Article I declares that "all Legislative Powers herein granted shall be vested in a Congress of the United States," and nowhere else.

All of this detail indicates that the constitutional text resists the notion that an "independent, free-standing presidential law-making authority exists insofar as the rights of American citizens are concerned," as Professor Monaghan has put it. ${ }^{345}$ The executive power vested in the President by Article II, Section 1 is characterized by, as Hamilton argued in Federalist No. 75, "the execution of the laws and the employment of the common strength," which, he believed, "seem to comprise all the functions of the executive magistrate." "346 Hamilton had distinguished this power from the legislative power, "the essence" of which "is to enact laws, or in other words to prescribe rules for the regulation of the society." ${ }^{347}$ In the few cases addressing this distinction, the Supreme Court has continued to define the executive power by its very lack of the power to make laws. "In the framework of our constitution," the Court declared in Youngstown Sheet \& Tube Co. v. Sawyer, "the President's power to see that the laws are faithfully executed refutes the idea that he is to be a lawmaker." ${ }^{348}$ Whether one believes in a "law-enforcement,"349 "protective power," 350 or a broader inherent power model of the presidency ${ }^{351}$ none of these theories recognizes an executive authority to legislate upon the domestic legal rights and duties of American citizens without congressional authori-

343. See, e.g., Bradford R. Clark, Federal Common Law: A Structural Reinterpretation, 144 U. PA. L. Rev. 1245 (1996); Martha A. Field, Sources of Law: The Scope of Federal Common Law, 99 Harv. L. Rev. 883, 895-96 (1986); Henry J. Friendly, In Praise of Erie And of the New Federal Common Law, 39 N.Y.U. L. REV. 383, $405-07$ (1964); Larry Kramer, The Lawmaking Power of the Federal Courts, 12 PACE L. REv. 263, 287 (1992); Thomas W. Merrill, The Common Law Powers of Federal Courts, 52 U. CHI. L. REV. 1, 17 (1985); Henry P. Monaghan, Hart and Wechsler's The Federal Courts and the Federal System, 87 HARV. L. REV. 889, 892 (1974) (book review).

344. See, e.g., INS v. Chadha, 462 U.S. 919, 959 (1983).

345. Monaghan, supra note 231 , at 4.

346. THE FEDERALIST No. 75, supra note 326, at 482.

347. Id.

348. Youngstown Sheet \& Tube Co. v. Sawyer, 343 U.S. 579,587 (1952).

349. Monaghan, supra note 231, at 10.

350. Id. at 11 .

351. See generally Calabresi \& Prakash, supra note 44. 
zation. Allowing the President and Senate, through the treaty power, to exercise powers allocated by the Constitution to Congress would step over this line.

Using the statutory form to make international agreements that regulate matters within Congress's Article I powers avoids conflict between the textual grants of the executive and legislative power to different branches of government. According to internationalists, the President and Senate may resort to the treaty process to address any matter, so long as it is "an agreement between two or more states or international organizations that is intended to be legally binding and is governed by international law." 352 If treaties are this unlimited in subject-matter, and if they also are self-executing, then the treatymakers can regulate any area - even one that lies within the enumerated powers of Congress. Under this approach, a self-executing treaty could make certain actions federal crimes or establish new commercial or environmental regulations, despite Congress's power over both matters domestically. As the line between domestic and international matters disintegrates, and as the United States turns to multilateral international agreements to address problems that were once domestic in scope, treaties potentially could replace statutes as a primary vehicle for domestic regulation. For example, if an international agreement, such as the GATT, required that the United States make adjustments to its rules governing intellectual property or modify its regulation of foods and drugs, internationalists would conclude that the treatymakers could enact these changes directly under their Treaty Clause authority. Internationalists agree with this result, even when there is no doubt that, in the absence of a treaty, the President and Senate could not achieve the same result without the participation of the House. ${ }^{353}$

This approach threatens to read out of the Constitution Article I's vesting of legislative powers in Congress alone. It invites conflict between the treaty power and the legislative power, and it resolves this clash by allowing one clause of the Constitution essentially to trump the other. Further, the exclusivist position too easily removes the House from its constitutional role in domestic policymaking and creates an inviting loophole for an expansive use of the treaty power. Recognizing these problems, the Restatement and leading internationalist scholars admit that treaties cannot take direct effect as American law if legislation is "constitutionally required." 354 Both Professor Henkin and the Restatement concede that legislation appears to be

352. RESTATEMENT (THIRD), supra note 7, at $\$ 301$ (1). See also Damrosch, supra note 52 , at 530 .

353. See, e.g., HENKIN, FOREIGN AFFAIRS, supra note 6, at 194-98; Paust, supra note 337 , at $776-81$.

354. RESTATEMENT (THIRD), supra note 7 , at $\$ 111(4)(\mathrm{c})$. 
necessary to implement a treaty if the international agreement calls for a declaration of war, an appropriation of money, the raising of taxes, or the punishment of criminal conduct. ${ }^{355}$ Neither, however, provides any principle that distinguishes those areas that are to be reserved to statutes from the other powers that are subject to the treaty power. The constitutional text, which treats all of these powers in Article I, Section 8, certainly does not make any distinctions among them..$^{356}$

Indeed, if internationalists are correct in arguing that a treaty can exercise a single Article I, Section 8 power granted to Congress, then the treatymakers must be able to exercise all of Congress's legislative powers. If the President and the Senate, for example, can use a treaty to establish commercial regulations or intellectual property rules, there is no textual reason that should prevent a treaty from declaring war or establishing criminal punishments. Internationalist efforts to preserve congressional control over appropriations, war declaration, and crimes, makes even less sense in light of the absence of any constitutional provision vesting Congress with a power to enact general federal criminal laws. As most federal criminal laws must be based upon the Commerce Clause, the Henkin/Restatement distinction collapses, as these authorities agree that the treatymakers can exercise the Commerce Clause power without resort to a statute. The internationalists fail to provide any reason rooted in the constitutional text or structure why treaties can establish trade regulations but cannot enact criminal laws.

A logic that would make treaties the exclusive means of making international agreements, combined with standard internationalist theories of the treaty power, leads to the conclusion that the treatymakers can exercise virtually any and all of the federal government's legislative powers. This conclusion is fundamentally at odds with the Constitution's reservation of legislative authority to a popularly elected Congress. As Madison declared during the Jay Treaty debates, "if the Treaty-power alone could perform any one act for which the authority of Congress is required by the Constitution, it may perform every act for which the authority of that part of the Government is required."357 Madison further argued that if by treaty "the President and Senate can regulate Trade; they can also declare war; they can raise armies to

355. See id. at $\$ 111 \mathrm{cmt}$. i \& reporters' note 6; HENKIN, FOREIGN AFFAIRS, supra note 6 , at 203 .

356. The one exception is the Appropriations Clause, which declares: "No Money shall be drawn from the Treasury, but in Consequence of Appropriations made by Law." U.S. CONST. art. I, $\$ 9$, cl. 7. Professor Henkin and the Restatement admit that use of the term "by Law" indicates that appropriations can only be made by a statute, rather than by a treaty. This reading, however, undermines their approach to the Supremacy Clause, which is built on the idea that a treaty is the constitutional equivalent of a "Law."

357. Speech by James Madison on Jay's Treaty, supra note 234, at 258. 
carry on war; and they can procure money to support armies." 358 Madison believed that this result demonstrated that the treaty power could not be read so far as to enjoy legislative authority, because the Constitution vested Article I, Section 8's powers in Congress specifically to ensure that the House played a determinative role in their exercise. "[A]lthough the Constitution had carefully \& jealously lodged the power of war, of armies, of the purse \&c. in Congress, of which the immediate representatives of the people, formed an integral part," Madison observed, an exclusivist theory of treaties meant that the:

President \& Senate by means of Treaty of Alliance with a nation at war, might make the United States parties in the war: they might stipulate subsidies, and even borrow money to pay them: they might furnish Troops, to be carried to Europe, Asia or Africa: they might even undertake to keep up a standing army in time of peace, for the purpose of cooperating, on given contingences [sic], with an Ally. ${ }^{359}$

Some internationalists wisely concede that only Congress can exercise certain powers, such as appropriations and taxation. The exclusion of these areas from the general rule of self-execution makes sense when viewed as a matter of democratic policymaking. Clearly, matters such as declaring war, raising taxes, and imposing criminal penalties are some of the most vital exercises of the legislative power, and they have never been thought to lie with the judiciary or executive. ${ }^{360}$ This principle, however, also argues against allowing the treatymakers to transfer to themselves any of the powers vested exclusively in Congress under Article I, Section 8, because the Constitution itself does not textually distinguish among those powers. As Madison said during the Jay Treaty debates, "[t]hese powers, however different in their nature or importance, are on the same footing in the Constitution, and must share the same fate."361 Only by requiring congressionalexecutive agreements in areas that involve Congress's powers, or by adopting a presumption that treaties are non-self-executing, can this conflict between Articles I and II be resolved.

\section{Congressional-Executive Agreements as Public Lawmaking}

Maintaining the line between executive and legislative power, between treatymaking and lawmaking, better accords not just with the

358. Id.

359. Id. at 258-59. To prevent a permanent military establishment, Madison argued, the Constitution had vested appropriations in Congress and subjected military appropriations to a two-year limit, which intentionally coincided with the two-year cycle for House elections. "This is a most important check \& security agst. the danger of standing armies, \& against the prosecution of a war beyond its rational objects." Id. at 260.

360. See, e.g., Missouri v. Jenkins, 495 U.S. 33, 69 (1990) (Kennedy, J., dissenting) (arguing that the power of taxation is beyond the authority of the judicial branch).

361. Speech by James Madison on Jay's Treaty, supra note 234, at 258. 
constitutional text and structure, but also with the Constitution's system of democratic governance and popular sovereignty. In domestic spheres of activity, the Constitution grants the power to legislate to the federal government through the institution of Congress. The Constitution promotes the idea that when the government imposes rules of conduct on private individuals, those rules ought to be made by their most directly accountable representatives. This principle of popular sovereignty seems to demand that Congress usually participate in the promulgation of international agreements that require individuals to act or not act in certain ways, just as Congress is the dominant institutional force in the enactment of domestic laws that have the same effect. As modern treaties begin to encompass matters such as economics, industrial and environmental activity, individual liberties, and other areas that have usually been the preserve of domestic legislation, congressional-executive agreements impose the same process on the same subjects, regardless of whether the impulse for regulation comes from domestic or international sources.

Congressional-executive agreements promote democratic government in the public lawmaking process as it relates to international matters. Use of the statutory process requires the consent of the most directly democratic part of the government, the House of Representatives, before the nation can regulate domestic matters through international agreements. The treaty process allows a minority of Senators, representing perhaps even a smaller minority of the national population, to block international agreements. ${ }^{362}$ This point also has a flip side. While perhaps unlikely, it is also possible under the treaty process for two-thirds of the Senate to force the nation to enter into a treaty without the support of the majority of the people. According to recent population estimates, two-thirds of the Senate can represent as little as thirty-two percent of the population. If the sixteen most populous states opposed a treaty, producing thirty-two Senate votes out of one-hundred, they would represent 185.6 million of the nation's estimated 272.7 million people, or sixty-eight percent of the population. ${ }^{363}$ To be sure, the presence of a popularly elected President provides a safeguard against the chances of an anti-majoritarian treaty, but presidential participation is not a complete protection for majority rule, particularly once a President enters his or her second term. Establishing a process in which the House's prerogatives over domestic

362. See Ackerman \& Golove, supra note 13 , at 872 .

363. According to the Bureau of the Census, in 1999 the sixteen most populous states were (in millions of people): California: 33.1; Texas 20.0; New York 18.2; Florida 15.1; Illinois 12.1; Pennsylvania 12.0; Ohio 11.3; Michigan 9.9; New Jersey 8.1; Georgia 7.8; North Carolina 7.7; Virginia 6.9; Massachusetts 6.2; Indiana 5.9; Washington 5.8; Missouri 5.5. These figures are taken from Census Bureau estimates, available at http:/quickfacts.census. gov/qfd/ (last visited Mar. 7, 2001). 
legislation are preserved by the congressional-executive agreement provides yet another security for popular sovereignty.

In addition, the reasons that existed in the eighteenth century for excluding the House from the making of international agreements no longer seem as compelling as they once were. In deciding to commit treaties to the President and Senate, the Framers believed that the House was too numerous and unstable to participate in the secrecy required for diplomacy. Hamilton's comment in Federalist No. 75 was typical Federalist thinking: "The fluctuating, and taking its future increase into the account, the multitudinous composition of that body, forbid us to expect in it those qualities which are essential to the proper execution of such a trust." ${ }^{\prime 34}$ Today, however, the Senate has about fifty percent more members than the first House of Representatives envisioned by the Constitution, suggesting that the Senate no longer has the small numbers that the Framers believed necessary for successful diplomacy. ${ }^{365}$ Incumbency retention rates in the House, which regularly reach ninety percent, also suggest that the House may enjoy more stability, particularly. in its committees and leadership, than the Framers might have anticipated. ${ }^{366}$ Aside from the treaty process, the House today can play an equal role to the Senate in foreign policy, with committees on international relations, national security, and intelligence that routinely handle sensitive information.

Furthermore, the Senate never assumed the active role in foreign policy that some Framers may have anticipated. President Washington's attempt in the first year of the Republic to consult with the sitting Senate on a potential treaty proved unsuccessful; the Senate proved too numerous and unwieldy to provide much help with diplomatic negotiations ${ }^{367}$ Rather than before-the-fact advice, the Senate's formal role in treatymaking has become one of after-the-fact consent, a function that does not especially demand small numbers. The President and the executive branch are responsible for setting foreign policy goals and maintaining confidentiality during the conduct of negotiations. Even if the Senate possessed some superiority in diplomacy over the House, the nature of the multilateral, regulatory treaties that make the most legislative demands do not require secrecy or speed of action. It is those treaties that have the least domestic regulatory effect, such as arms control or military alliance agreements, which demand the most secrecy. Requiring that international agreements with the most domestic regulatory effect undergo approval by statute

364. THE FEDERALIST NO. 75, supra note 326, at 483.

365. See U.S. CONST. art. I, $\$ 2$, cl. 3 (indicating that the first House of Representatives was to have 65 members).

366. See NORMAN J. ORnStein ET AL., VITAL Statistics ON CONGRESS, 1997-1998, at 47-49, 64-65 (1998).

367. The episode is described in ELKINS \& MCKITRICK, supra note 66, at 55-58. 
would have little impact on the nation's ability to negotiate these types of compacts.

Mandating that treaties serve as the exclusive method for making international agreements, on the other hand, would generate tension in the public lawmaking process. Just as complete interchangeability creates textual and structural difficulties by importing certain doctrines that applied only to statutes into the foreign policy making process, so too does treaty exclusivity disrupt the finely tuned statutory methods for regulating domestic affairs. Allowing treaties to exercise legislative power would shift the locus of lawmaking from the legislature to the executive branch. Laws begin in Congress, where they are introduced by Members and referred to committees that hold hearings to investigate the issue, markup any legislation, and serve a gatekeeping function in controlling the flow of legislation to the floor. After receiving approval by the committees, statutes must receive the approval of both houses of Congress; differences in the bills must be worked out by a conference between the House and Senate. If the President vetoes the bill, both houses can still enact the legislation by two-thirds vote. Courts enforce the statute in keeping with the intentions of Congress, whether expressed in the statutory text or the legislative history. Although the President surely has a significant political role in the initiation and enactment of legislation, the institutional weight behind domestic policymaking gives Congress at least an equal, if not dominant, role in the passage of statutes.

Using treaties to perform the same function as statutes has two effects on the public lawmaking process. First, although the Constitution provides for a Senate "advice and consent" function, this role has become one of after-the-fact consent. The President, not the Senate, decides whether to negotiate with other countries and on what subjects. It is the executive branch, rather than the House or Senate, which conducts the negotiations and actually concludes the treaty. Indeed, the Constitution forbids Congress from sending its own representatives in foreign negotiations because of the President's plenary power to appoint and receive ambassadors. ${ }^{368}$ Further, the Court has read the Constitution to vest the President with the plenary power to serve as the "sole organ" of the nation in its foreign relations. ${ }^{369}$ As I argue elsewhere, the President takes the primary role in enforcing treaties, and it is often his understanding, as expressed to the Senate during the advice and consent process, that counts in future interpretation of the

368. See U.S. CONST, art. II, $\$ 2$, cl. 2 (The President "by and with the Advice and Consent of the Senate, shall appoint Ambassadors"); id. art. II, $\$ 3$ (President "shall receive Ambassadors and other public Ministers").

369. See United States v. Curtiss-Wright Export Corp., 299 U.S. 304, 320 (1936). 
treaty. ${ }^{370}$ The executive's dominance of the treaty process makes sense because the President - rather than the Senate - is charged with the bulk of the foreign affairs power, the President controls the conduct of diplomacy, and the President serves as Commander-in-Chief. Demands for flexibility, speed, and unity of action in foreign affairs have almost inevitably led to the flow of power to the executive.

Second, requiring that treaties enjoy legislative power threatens to import these pro-executive structures into the normal lawmaking process. Executive branch officials usually negotiate treaties with little formal input from Congress. Presidents refer the negotiated agreement to the Senate almost as a fait accompli, in which the Senate has little freedom to modify the substantive provisions. ${ }^{371}$ The understandings of the agreement that will govern will often be those of the President and his or her advisers, not those of the congressional committees or individual Senators. Because the process that applies will be that of the Treaty Clause, the President will come to exercise broader powers over the domestic lawmaking process than would normally be the case. Termination of treaties draws these problems into sharp relief. Statutes require a repealing statute to terminate their provisions. As discussed earlier, however, most authorities conclude that treaties may be terminated by unilateral presidential action. ${ }^{372}$ This conclusion creates an inconsistency in the constitutional structure. If the political branches choose to regulate domestic conduct by statute, the President cannot terminate the rules without Congress's permission. If, however, the political branches should regulate the same conduct by treaty, the President can terminate the regulation at will. Treaty exclusivity, therefore, has the effect of expanding the President's powers as more and more aspects of domestic life can be regulated by international agreement, rather than by statute. A doctrine whereby congressional-executive agreements are needed to enter into agreements that have domestic legislative effects preserves the balance of powers among the branches.

370. See John C. Yoo, Review Essay, Politics as Usual?: The Anti-Ballistic Missile Treaty, the Separation of Powers, and Treaty Interpretation, 89 CAL. L. REV. 851 (forthcoming 2001). Presidential dominance in treaty enforcement and interpretation was heavily contested during the controversy over whether the ABM treaty permitted "Star Wars" research. See, e.g., Joseph R. Biden, Jr. \& John B. Ritch III, The Treaty Power: Upholding a Constitutional Partnership, 137 U. PA. L. REV. 1529 (1989); Lawrence J. Block et al., The Senate's Pie-in-the-Sky Treaty Interpretation: Power and the Quest for Legislative Supremacy, $137 \mathrm{U}$. PA. L. REV. 1481 (1989); Abram Chayes \& Antonia Handler Chayes, Commentary, Testing and Development of "Exotic" Systems Under the ABM Treaty: The Great Reinterpretation Caper, 99 HARV. L. REV. 1956 (1986); Abraham D. Sofaer, Commentary, The ABM Treaty and the Strategic Defense Initiative, 99 HARV. L. REV. 1972 (1986).

371. Under fast track legislation, Congress cannot even modify or amend congressionalexecutive agreements involving trade. See Harold Hongju Koh, The Fast Track and United States Trade Policy, 18 BrooK. J. INT'L L. 143 (1992).

372. See supra note 228. 
Congressional-executive agreements represent the political branches' best effort to preserve a distinction between treatymaking and lawmaking. Section II demonstrated the textual and structural difficulties that arise from a doctrine of complete interchangeability, in which statutes could utterly replace treaties. This Part has shown the similar constitutional problems created by the alternative theory of treaty exclusivity. In conjunction with the theory of self-execution and the growing internationalization of domestic affairs, treaty exclusivity provokes an irreconcilable conflict between the grant of the treaty power to the executive branch, and the vesting of all federal legislative power in Congress. Congressional-executive agreements provide a way to resolve this tension by allowing Congress to retain authority over those matters delegated to it by the Constitution, even when an international agreement threatens to intrude upon its plenary powers. Unlike the internationalist or transformationist theories, however, this approach still reserves a meaningful role for treaties in the conduct of foreign policy. If congressional-executive agreements are needed to make international agreements in areas of Congress's Article I, Section 8 powers, the political branches still must use treaties to enter into agreements that either lie outside of those limits or that involve areas where the executive and legislature possess competing powers.

\section{Statutes, Treaties, and the Future of International Agreements}

Conceiving of congressional-executive agreements as occupying the sphere of international agreements that involve Congress's Article I powers has several implications for foreign affairs law and the making of international agreements. It predicts what types of future international agreements will undergo the statutory or treaty processes. It indicates how the political branches may address several of the difficulties that will arise with future international agreements. It also provides an understanding of the changing choice of instruments over time. Two developments make the choice of statute versus treaty significant. As domestic affairs become internationalized, international agreements will come to play a more important role in domestic regulation. At the same time, the Supreme Court's effort to protect state sovereignty and impose new checks on congressional power removes more areas from the reach of the legislature. This phenomenon may place pressure on the political branches to turn to treaties to engage in the regulation of non-commercial activities or individual rights. $\mathrm{Be}$ cause of these trends, whether the political branches adopt an international agreement by treaty or by statute will bear important consequences for the scope of federal jurisdiction and the substance of national regulation.

Before turning to these issues, it is worth addressing questions about the status of congressional-executive agreements under interna- 
tional law. Treaties as defined by the Article II, Section 2 and Article VI of the Constitution constitute treaties for purposes of international law. One might ask whether congressional-executive agreements, in which Congress merely enacts an international agreement as a statute, can rise to the same level of international obligation as a treaty, which represents the assent of both the President and a supermajority of the Senate. International law, however, as represented by the Vienna Convention on the Law of Treaties and customary international law, defines an international agreement as "an agreement between two or more states or international organizations that is intended to be legally binding and is governed by international law." ${ }^{373}$ From this broad definition, it is apparent that international law is willing to consider treaties, congressional-executive agreements, and even sole executive agreements all as species of international agreements that are equally binding on the United States. Even though congressional-executive agreements have not undergone the same domestic process as a treaty, there is an agreement - the President negotiates and signs a document - and it becomes domestically binding once it receives approval from Congress.

While they may appear identical under international law, the difference between statutes and treaties makes a significant difference for domestic purposes. The constitutional differences between the two will dictate what form the political branches must use to enter into certain types of international agreements. Future trade agreements, such as the accession of the People's Republic of China to the WTO, new WTO rounds, or expansion of American free trade areas will continue to undergo the statutory process because they involve Congress's powers over foreign commerce. Agreements that rest outside Congress's plenary powers, such as human rights, political-military, and arms control, will still require use of the Treaty Clause. Some areas, such as the environment, may lie somewhere in between. Although much domestic environmental legislation presumably passes constitutional muster under the Commerce Clause, the non-commercial nature of proposed international environmental agreements and the Supreme Court's new restrictions upon the Commerce Clause may require use of the treaty form. As the scope of the Commerce Clause recedes and efforts to harmonize domestic regulation with international standards increase, the Treaty Clause may present a more reliable source for legislative power.

373. RESTATEMENT (THIRD), supra note 7, at $\$ 301(1)$; see also Vienna Convention on the law of treaties, May 23, 1969, arts. 1-2, 1155 U.N.T.S. 331, 333. The treaty entered into force on January 27, 1980. Although the United States has not ratified the Vienna Convention on the Law of Treaties, the executive branch has decided to follow many of its substantive provisions as a matter of practice. 
Recent decisions on the scope of state sovereignty show how the distinction between congressional-executive agreements and treaties might play out. Under the Agreement on Trade-Related Aspects of Intellectual Property Rights (TRIPs), ${ }^{374}$ which itself is part of the WTO agreement, state parties agreed to establish minimum substantive protections for intellectual property and to provide for judicial remedies, including compensatory relief, against infringers. ${ }^{375}$ Under Seminole Tribe $v$. Florida,${ }^{376}$ however, Congress may not provide a remedy in federal court for damages against a State, and under Alden v. Maine ${ }^{377}$ the same is true in state court. Even when Congress has used its Section 5 powers under the Fourteenth Amendment, rather than its Commerce Clause power under Article I, the Court has invalidated comprehensive efforts to protect intellectual property rights without a showing of systematic state violations of that right. ${ }^{378}$ These decisions appear to place the United States in violation of TRIPs by eliminating judicial remedies for violations of intellectual property rights against a class of potential infringers. ${ }^{379}$

TRIPs could have provided a different source of power upon which to base new federal legislation against the states to protect intellectual property. Indeed, Professor Peter Menell, among others, has suggested using the treaty power to restore protections for federal intellectual property rights against the states. ${ }^{380}$ But the difference between treaties and congressional-executive agreements may raise an insurmountable stumbling block. Because the political branches chose to enter into the WTO agreement as a congressional-executive agreement, TRIPs cannot enjoy the broader constitutional scope that applies to treaties. If the President and Senate had approved TRIPs as a treaty, they could have accessed the broader powers of Missouri v. Holland to impose obligations free from the "invisible radiations" of the Tenth Amendment. Since the Court has repeatedly made clear that state sovereign immunity applies only to statutes that draw upon Congress's Article I authority, TRIPs could have escaped Seminole Tribe and Alden because its power would have emanated from Article II's Treaty Clause. Efforts to establish judicial remedies for intellectual property by treaty also would not fall subject to the Court's in-

374. TRIPS Agreement, supra note 270.

375. Id. arts. $41,44-45$.

376. 517 U.S. 44 (1996).

377. 527 U.S. 706 (1999).

378. College Sav. Bank v. Florida Prepaid Postsecondary Educ. Expense Bd., 527 U.S. 666 (1999).

379. See Peter S. Menell, Economic Implications of State Sovereign Immunity From Infringement of Federal Intellectual Property Rights, 33 LOY. L.A. L. REV. 1399, 1452-53 (2000).

380. See id. at 1460-64. 
creasingly difficult test for remedial statutes enacted under Section 5 of the Fourteenth Amendment. But because Congress cannot escape these decisions when acting by statute, use of the congressionalexecutive agreement has the consequence of restricting the national government's ability to implement international obligations on intellectual property.

Even this use of the treaty power to overcome the Court's recent federalism decisions may not be utterly free from doubt. Professor Curtis Bradley, for example, has argued recently that the treatymakers' power to create federal law ought to be subject to the same federalism limits that apply to Congress. ${ }^{381}$ As a formal matter, this argument may not be compelling because federalism limitations may not apply in the same manner to Articles I and II. As a matter of the original understanding, this argument does not seem to stand on firm ground: both the Treaty of Peace of 1783 and the Jay Treaty of 1795, both entered into by the framing generation, regulated issues such as access to state courts and the right to hold and dispose of property issues that would not have been within Congress's enumerated powers as they were understood at the time. Nonetheless, Bradley's claim has a certain structural appeal, because it harmonizes treaties within the existing constitutional model of limited and enumerated powers and the Court's recent federalism jurisprudence in the state sovereignty area.

Another potential limit on the treaty power might arise from the Eleventh Amendment itself. If one believes the standard story concerning the Eleventh Amendment, it was enacted in response to the Court's decision in Chisholm v. Georgia, ${ }^{382}$ which had allowed a citizen of the state of South Carolina to sue for damages against the state of Georgia. ${ }^{383}$ In itself, this rule does not explain the nation's overwhelming rejection of the decision. Rather, the outcry in Congress and among the public was so great because of the issue of the prerevolutionary debts owed to British creditors. ${ }^{384}$ Under the Peace Treaty of 1783, the United States had agreed that "no lawful impediments" would stand in the way of British creditors seeking to recover from American debtors. ${ }^{385}$ Nonetheless, many states refused to allow

381. See Bradley, supra note 258, at 394.

382. 2 U.S. (2 Dall.) 419 (1793).

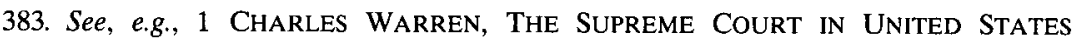
HISTORY 91-102 (1922).

384. See Emory G. Evans, Planter Indebtedness and the Coming of the Revolution in Virginia, 19 WM. \& MARY Q. (3d ser.) 511 (1962); Emory G. Evans, Private Indebtedness and the Revolution in Virginia, 1776 to 1796, 28 WM. \& MARY Q. (3d ser.) 349, 359-67 (1971); Charles F. Hobson, The Recovery of British Debts in the Federal Circuit Court of Virginia, 1790 to 1797, 92 VA. MAG. HIST. \& BIOGRAPHY 176 (1984)

385. Definitive Treaty of Peace Between Great Britain and the United States, Sept. 3, 1783, U.S.-Gr. Brit., art. IV, 48 Consol. T. S. 487, 493. 
their courts to hear such claims. Some states had assumed the debts of the individual debtors; many expected that sovereign immunity would prevent the federal courts from adjudicating creditor suits against these states. Chisholm generated a national controversy because it raised the specter that British creditors, freed from state sovereign immunity, would be able to sue states directly under a treaty-granted cause of action. ${ }^{386}$ If this historical understanding guides interpretation of the Eleventh Amendment, then state sovereignty immunity may prove to have an equal effect upon treaties as it does upon statutes.

\section{CONCLUSION}

This Article has sought to provide a constitutional justification for the congressional-executive agreement. It criticizes reliance upon dubious historical claims of a non-amendment constitutional amendment or of a long-running pedigree of interchangeability. Rather, congressional-executive agreements find support in Congress's plenary Article I, Section 8 powers to regulate interstate and international commerce, among other powers. Unlike claims of interchangeability, this Article's approach explains that there are continuing spheres of action for both treaties and statutes in enacting international agreements. Treaties are still a constitutionally required form when an international agreement calls for actions that lie outside of Congress's constitutional powers. Unlike claims of treaty exclusivity, however, this approach leaves ample room to the political branches to use congressional-executive agreements in areas of congressional competence.

Maintaining this line between congressional-executive agreements and treaties achieves two larger goals. First, it maintains a distinction between the executive and legislative powers, which allows Congress to check executive branch foreign policy that has direct domestic effects. Second, this line comports closely with the practice of the political branches since the end of World War II. If the nation is to enjoy the benefits of a choice of instruments to pursue its foreign policy goals, it needs a constitutional theory to explain the co-existence of both treaties and congressional-executive agreements. This Article has supplied a possible theory.

386. See 1 Julius Goebel, JR., History of THE SuPreme COURT OF THE UNITED STATES: ANTECEDENTS AND BEGINNINGS TO 1801, at 734-41 (1971); 1 WARREN, supra note 383 , at $96-102$. The $\$ 500$ minimum requirement for diversity jurisdiction was also an effort to exclude these suits from the federal court, because most of the debt claims fell below this amount. See, e.g., William R. Casto, The Supreme CoURT IN THE EARLy Republic: THE CHIEF JUSTICESHIPS OF JOHN JAY AND OLIVER ELLSWORTH 98 (1995). 